\title{
STRESS CORROSION CRACKING OF CANDIDATE WASTE CONTAINER MATERIALS - FINAL REPORT
}

by

J. Y. Park, P. S. Malya, W. K. SSoppet, D. R. Diercks,

W. J. Shack, and T. F. Kassner

Materials and Components Technology Division

June 1992

Work sponsored by

U.S. DEPARTMENT OF ENERGY

under subcontract from Lawrence Livermore National Laboratory (ACK 85861)

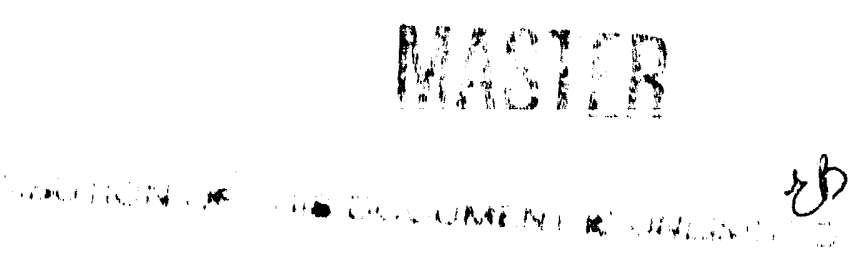




\section{Contents}

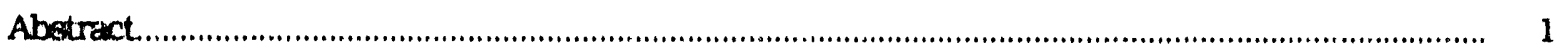

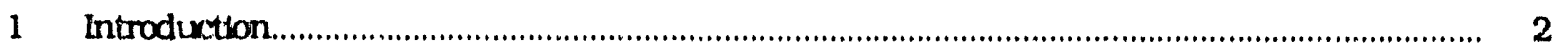

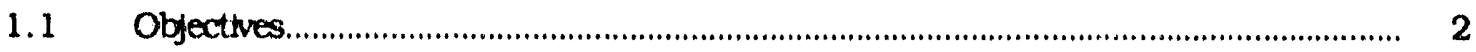

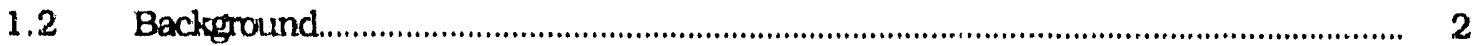

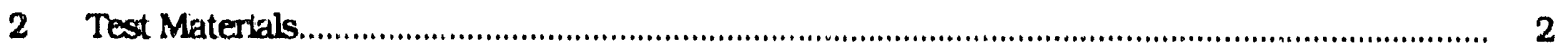

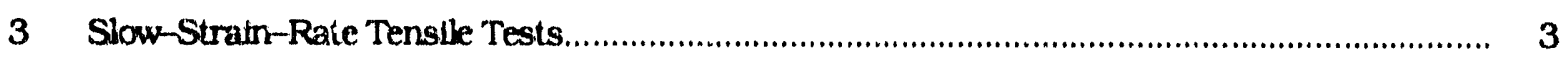

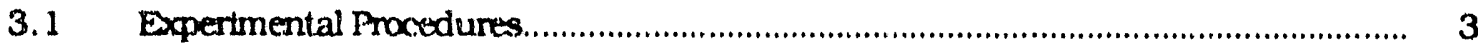

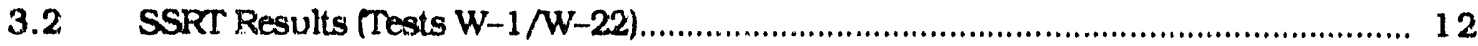

3.2.1 Observations of SCC by SEM.............................................................. 12

3.2.2 Estimation of Local Plastic Strains........................................................... 16

3.2.3 Relative SCC Susceptibility of Waste Container
Matenals................................................................................................ 24

3.2.4 SCC Susceptibility of Weldment Specimens...................................... 26

- 3.2.5 Influence of Strain Rate on SCC.............................................................. 31

3.2.6 Measurement of Crack Depth in SSRT Spectmens.......................... 31

3.2.7 Influence of Water Chemistry on SCC........................................... 31

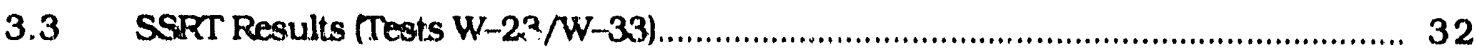

3.3.1 Crack Depth Distribution in SSRT Spectmens................................... 32

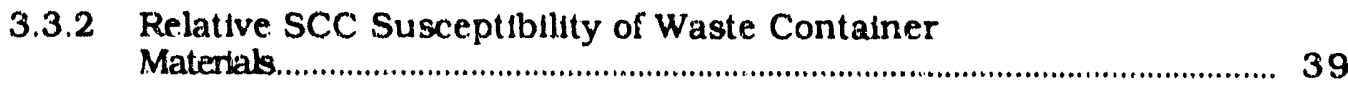

3.3.3 Induence of Strain Rate on SCC....................................................... 51

3.4 Preparation and Analyses of Test Solutions.................................................... 51

3.5 Measurement of Electrochemical Potential.................................................... 57

4 Fracture-Mechanics Crack-Growth-Rate Tests............................................................61 61

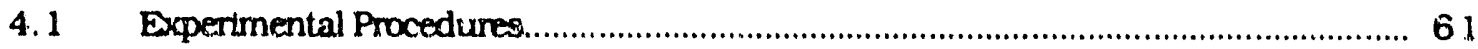

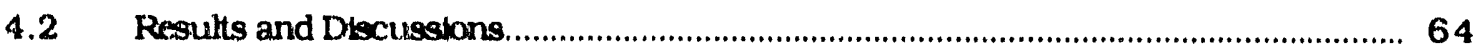

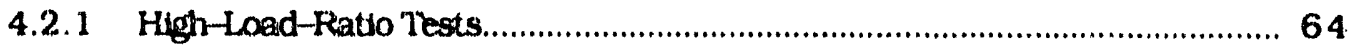

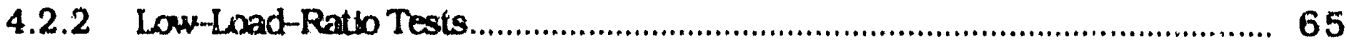

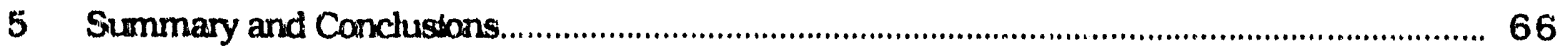

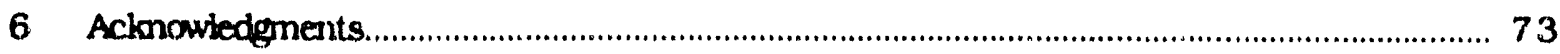

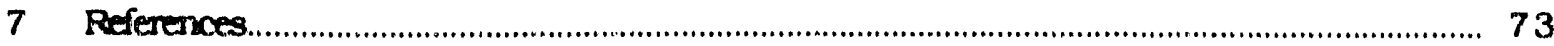




\section{Figures}

1 Fabrtcation Drawing for Base Metal SSRT Spectmen.................................................. 10

2 Fabrication Drawing for Gas-Metal-Arc Welded Spectmen................................... 10

3 Fabrication Drawing for Electron-Beam-Welded Specimen................................. 11

4 Schematic of SSRT Setup with Feedwater and Electrochemical Potential Monitartng Systemis.......................................................................................... 11

5 Cross-Sectional View of Drilled Hole in SSRT Specimen.................................... 12

6 SEM Photomicrographs of Hole Regions of Type 304L SS and Incoloy 825........ 15

7 SEM Photomicrographs of Hole Regions of Welded Incoloy 825 Internupted after $\varepsilon_{\mathrm{p}}=2.3 \%$

8 SEM Photomicrographs of Cracks in Hole Regions of $\mathrm{Cu}$ and CurBase Alloys.

9 SEM Photomicrographs of Cracks in Hole Regions of Welded Type 316L SS Interrupted after $\varepsilon_{p} 3.0 \%$.

10 SEM Photomicrographs of Cracks in Hole Regions of Welded Type 316 SS Internupted after $\varepsilon_{\mathrm{p}}=3.0 \%$

11 SEM Photomicrographs of Hole Regions of Incoloy 825

Interrupted after $\varepsilon_{\mathrm{p}}=3.0 \%$.

12 SEM Photomtcrographs of Hole Regions for Incoloy 825 and $\mathrm{Cu}-30 \% \mathrm{Ni}$

13 Strain Concentration Factor as a Function of Plastic Strain for $\mathrm{Cu}$.

14 Strain Concentration as a Function of Plastuc Strain for Type 316L SS

15 Relative Cracking Susceptibllity of Six Candidate Materlals in Simulated Weil $\mathrm{J}-13$ Water at $93^{\circ} \mathrm{C}$

16 Relative Cracking Susceptibility of Six Candidate Matertals in Simulated Well $\mathcal{L} 13$ Water at $93^{\circ} \mathrm{C}$

17 Comparison of SCC Susceptibility of Type 304L SS Base Metal and Weldment Spectmens in Stmulated J-13 Water at $93^{\circ} \mathrm{C}$.

18 Comparison of SCC Susceptibllity of Type 316L SS Base Metal and Weldment Spectmens in Stmulated $J-13$ Water at $93^{\circ} \mathrm{C}$.

19 Comparison of SCC Susceptiblity of Incoloy 825 Base Metal and Weldment Spectmens in Simulated J-13 Water at $93^{\circ} \mathrm{C}$.

20 Comparison of SCC Susceptibility of $\mathrm{Cu}$ Base Metal and Weldment Spectrnens in Stmulated $\mathrm{J}-13$ Water at $93^{\circ} \mathrm{C}$.

21 Comparison of SCC Suscept lbility of Cu-30NI Base Metal and Weldment Spectrmens in Stmulated $\mathrm{J}-13$ Water at $93^{\circ} \mathrm{C}$.

22 Compartson of SCC Susceptibility of Incoloy 825 Incoloy Weldment Specimens with Two Dufferent Filler Materials in Simulated J-13 Water at $93^{\circ} \mathrm{C}$ 
23 Comparison of SCC Susceptiblity of Cu-7Al Base, Electron-Beam-Welded, and Gas-Metal-Arc Welded Specimens in Simulated $\mathrm{J}-13$ Water at $93^{\circ} \mathrm{C}$.

24 Effect of Straln Rate and Specimen ECP on SCC Susceptibility of Type $304 \mathrm{~L}$ SS in Stmulated $J-13$ Water at $93^{\circ} \mathrm{C}$.

25 Effect of Strain Rate and Specimen ECP on SCC Susceptibility of Type $316 \mathrm{~L}$ SS in Stmulated $\mathrm{J}-13$ Water at $93^{\circ} \mathrm{C}$

26 Effect of Strain Rate and Specimen ECP on SCC Susceptibility of Incoloy $825 \mathrm{tn}$ Strnulated $\mathrm{J}-13$ water at $93^{\circ} \mathrm{C}$.

27 Effect of Strain Rate and Specimen ECP on SCC Susceptlbility of Cu in Stmulated $\mathrm{J}-13$ Water at $93^{\circ}$

28 EIfect of Strain Rate and Specimen ECP on SCC Susceptibility of Cu-7Al th Struulated $J^{-13}$ Water at $93^{\circ} \mathrm{C}$

29 Effect of Strain Rate and Specimen ECP on SCC Susceptibility of Cu-3ONI in Stmulated $\mathrm{J}-1.3$ Water at $93^{\circ} \mathrm{C}$

30 SCC Susceptibility of Incoloy 825 , as Indicated by Stress Ratio for Tests with Different Water Chemistries under Approximately the Same ECP Conditions at $93^{\circ} \mathrm{C}$.

31 SCC Susceptibllity of $\mathrm{Cu}$ in Terms of Stress Ratio for Tests Conducted in Stmulated Water without and with $\approx 1.0 \mathrm{ppm} \mathrm{H}_{2} \mathrm{O}_{2}$ at $93^{\circ} \mathrm{C}$.

32 Crack Depth Distribution on a Metallographically Polished Surface of a Transversely Sectioned Type 316i SS Specimen.

33 Maximum Crack Depth as a Function of Material Removed for SSRT Spectmens.

34 Nominal Stress versus Plastic Strain for Incoloy 825 Specimen in Simulated $\mathrm{J}-13$ Water at $93^{\circ} \mathrm{C}$.

35 Nominal Stress versus Plastic Strain for $\mathrm{Cu}-30 \mathrm{NI}$ in Simulated J-13 Water at $93^{\circ} \mathrm{C}$.

36 Variation of Stress Ratio with Plastic Strain for Incoloy 825 in Simulated H.13 Water at $93^{\circ} \mathrm{C}$.

37 Variation of Stress Rallo with Plastic Strain for $\mathrm{Cu}-30 \mathrm{NI}$ in Simulated $\mathrm{J}-13$ Water at $93^{\circ} \mathrm{C}$.

38 Nominal Stress versus Plastic Strain for Type 3041. SS in Simulated $\mathcal{H}-13$ Water at $93^{\circ} \mathrm{C}$.

39 Varlation of Stress Ratlo versus Plastic Strain for Type 304L SS in Strulated $\mathcal{J}-13$ Wates at $93^{\circ} \mathrm{C}$.

40 Nominal Stress versus Plastic Strain for Incoloy 825 in Simulated N-13 Water at $93^{\circ} \mathrm{C}$.

41 Vartation of Stress Ratio versus Plastic Strain for Incoloy 825 in Stmulated $\mathrm{J}-13$ Water at $93^{\circ} \mathrm{C}$.

42 Nominal Stress versus Plastic Strain for Cu-7Al in Simulated J-13 
43 Variation of Stress Ratio versus Plastic Strain for $\mathrm{Cu}-30 \mathrm{Ni}$ in Simulated $\mathcal{}-13$ Water at $93^{\circ} \mathrm{C}$.

44 Comparison of Stress Versus Plastic Strain for Two Tests on Type $304 \mathrm{~L}$ SS in Simulated $\mathrm{J}-13$ water at $93^{\circ} \mathrm{C}$.

45 Comparison of Stress Versus Plastic Strain for Two Tests on Type 316L SS in Simulated J-13 Water at $93^{\circ} \mathrm{C}$.

46 Compartson of Stress Versus Plastic Strain for Two Tests on Incoloy 825 in Stmulated $\mathrm{J}-13$ Water at $93^{\circ} \mathrm{C}$.

47 Comparison of Stress Versus Plastic Strain for Two Tests on Cu-30Ni

in Simulated $\mathrm{J}-13$ Water at $93^{\circ} \mathrm{C}$

48 Comparison of Stress Versus Plastic Strain for Two Tests on Cu-7Al in Stmulated $\mathrm{J}-13$ Water at $93^{\circ} \mathrm{C}$.

49 Relative Cracking Susceptibility of Five Alloys in Simulated J-13

Water at $93^{\circ} \mathrm{C}$, Expressed in Terms of Nominal Stress Ratio.

50 Relative Cracking Susceptibility of Five Alloys in Simulated J-13

Water at $93^{\circ} \mathrm{C}$, Expressed in Terms of Nominal Strain Ratio.

51 Cracking Susceptiblity of Incoloy 825 and $\mathrm{Cu}-30 \mathrm{NI}$ in Terms of Stress

Ratio or Strain Ratio in $J-13$ Water at $93^{\circ} \mathrm{C}$.....

52 Relative Cracking Susceptibility of Five Alloys in Simulated $\mathrm{J}-13$ Water

at $93^{\circ} \mathrm{C}$. Expressed in Terms of Nominal Stress Ratio......

53 Relative Cracking Susceptibility of Five Alloys in Simulated J-13 Water ai $93^{\circ} \mathrm{C}$. Expressed in Terms of Nominal Strain Ratio.

54 Electrochemical Potential of Incoloy 825 and $\mathrm{Cu}-7 \% \mathrm{Al}$ Alloy SSRT Specimens at $93^{\circ} \mathrm{C}$ versus an External Reference Electrode as a Function of Thre during Tests $\mathrm{W}-13$ and $\mathrm{W}-15$

55 Potential for Converting E.CP Measurements from an External Silver Chloride Reference Scale as a Function of the $\mathrm{KCl}$ Concentration from Relations for Thermocell and Liquid Junction Potentials.

56 Influence of Temperature on the Potential for Converting ECP Measurements with an External Reference Electrode to the Standard Hydrogen Electrode from Relations for Thermocell and Liquid Junction Potent Lals. 60

57 Design of Compact Tension Crack-Growth-Rate Test Specimen. 63

58 Schematic Representation of Experimental Setup and Test Specimen.....

59 Crack Length vs. Test Time for Type 304L SS at $\mathrm{K}_{\max }=25 \mathrm{MPa} \cdot \mathrm{m}^{1 / 2}$ and $\mathrm{R}=0.9$.

60 Crack Length vs. Test Time for Type $316 \mathrm{~L}$ SS at $K_{\max }=25 \mathrm{MPa} \cdot \mathrm{m}^{1 / 2}$ and $\mathrm{R}=0.9$.

61 Crack Length vs. Test Time for Incoloy 825 at $\mathrm{K}_{\max }=25 \mathrm{MPa} \cdot \mathrm{m}^{1 / 2}$ and $\mathrm{R}=0.9$.

62 Crack Length vs. Test Time for $304 \mathrm{~L}$. SS at $\mathrm{K}_{\max }=36 \mathrm{MPa} \cdot \mathrm{m}^{1 / 2}, \mathrm{R}=$ 0.7 and $0.5 \mathrm{~Hz}$ 
63 Time-Based CGR vs. Rate for Austenitic Stainless Steels in Air from ASME Section XI Correlation for $\mathrm{R}=0.5$

64 Time-Based CGR vs. Rate for Austenitic Stainless Steels in Alr from ASME Section XI Correlation for $R=0.7$

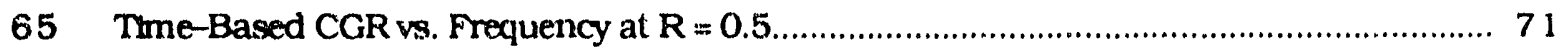

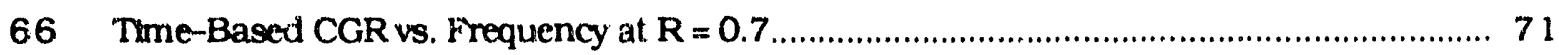

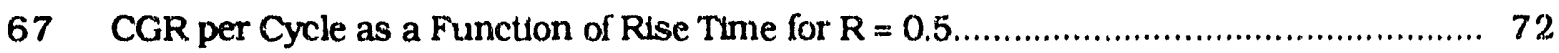

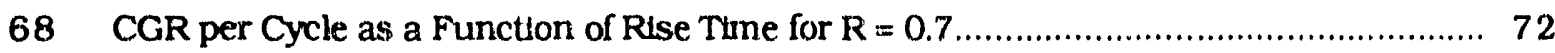




\section{Tables}

1 Elemental Composition of Well J-13 Groundwater.

2 Elemental Composition of Type 304L Stainless Steel Base Metal and Type 308L Stainless Stcel Weld Filler Metal.

3 Elemental Composition of Type 316L Stainless Steel Base Metal and Type 316L Statnless Steel Weld Filler Metal.

4 Elemental Composition of Incoloy 825 Base Metal and Inconel 625 and Inconel 65 Weld Filler Metal.

5 Elemental Composition of Phosphorus-Decoddtzed Copper.

6 Elemental Composition of the Cu-30\%NI Alloy and Monel 67 Weld Filler Metal.

7 Elemental Composition of the Aluminum Bronze Base Metal Alloys and Specifications for the Aluminum Bronze A2 Weld Filler Metal..

8 Selected Mechanical Properties of the Experimental Materials.

9 Yield Stress of Smooth Base and Welded Candidate Waste Container Matertals.

10 Summary of Expertmental Conditions for SSRT Tests.

11 SSRT Results for Candidate Container Materials in Simulated J-13 Water at $93^{\circ} \mathrm{C}$.

12 SSRT Results for Candidate Container Materials in Simulated J-13 Water at $93^{\circ} \mathrm{C}$.

13 SSRT Results on Weldment Specimens of Candidate Container Materials in Stmulated J-13 Water at $93^{\circ} \mathrm{C}$.

14 SEM Observations on SSRT Specimens of Candidate Waste Container Base Materials Tested in Strnulated J-13 Water at $93^{\circ} \mathrm{C}$.

15 SEM Observations on SSRT Specimens of Candidate Waste Container Weldment Spectmens Tested in Simulated $\mathrm{J}-13$ Water at $93^{\circ} \mathrm{C}$

16 SSRTs on Waste Container Materials at a Strain Rate of $1 \times 10^{-7} \mathrm{~g}^{-1}$ in Simulated $\mathrm{J}-13$ Water at $93^{\circ} \mathrm{C}$.

17 Chemical Composition of Effluent Water from SSRTs on Candidate Waste Container Materials. Tests W-l through W-9.

18 Chemical Composition of Emuent Water from SSRTs on Candidate Waste Container Materials, Tests W-10 through W-18.

19 Chemical Composition of Effluent Water from SSRTs on Candidate Waste Container Materials, Tests W-19 through W-27.

20 Chemical Composition of Effluent Water from SSRTs on Candidate Waste Container Matentals, Tests W-28 through W-33.

$21 \mathrm{pH}_{25^{\circ}} \mathrm{C}$ of Effluent Water and $\mathrm{pH}_{93^{\circ} \mathrm{C}}$ in Vessel during SSRTs in Stmulated J-13 Water. 
22 Steady-State Electrochemical Potential of Candidate Waste Container Materials, Platinum, and Nickel Test Vessel during SSRTs in

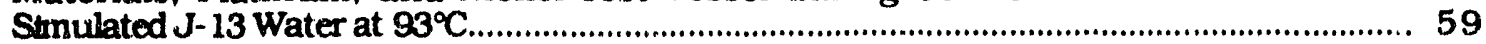

23 Chemical Composition of $\mathrm{J}-13 \mathrm{Well}$ Water and Test Solution....................................62 62

24 Loading Conditions for CGR Tests on Candidate Waste Container Materials.

25 Cyclic CGRs, Observed and Calculated with ASME Section XI Correlation. 67 


\title{
STRESS CORROSION CRACKING OF CANDIDATE \\ WASTE CONTAINER MATERIALS - FINAL REPORT
}

\author{
by
}

\author{
J. Y. Park, P. S. Matya, W. K. Soppet, D. R. Diercks, \\ W. J. Shack, and 'T, F, Kassner
}

\begin{abstract}
Six alloys have been selected as candidate container materials for the storage of highlevel nuclear waste at the proposed Yucca Mountain site in Nevada. These materials are Type 304L stainless steel (SS). Type 316L SS, Incoloy 825, phosphorus-deoxidized $\mathrm{Cu}, \mathrm{Cu}-$ $30 \% \mathrm{Ni}$, and $\mathrm{Cu}-7 \% \mathrm{Al}$. The present program has been initiated to determine whether any of these materials can survive for $\mathbf{3 0 0}$ years in the site environment without developing through-wall stress corrosion cracks, and to assess the relattve resistance of these materials to stress corrosion cracking (SCC). A series of slow-strain-rate tests (SSRTs) and fracture-mechanics crack-growth-rate (CGR) tests was performed at $93^{\circ} \mathrm{C}$ and 1 atm of pressure in simulated $J-13$ well water. This water is representative, prior to the widespread avallability of unsaturated-zone water, of the groundwater present at the Yucca Mountain site.
\end{abstract}

Slow-strain-rate tests were conducted on 6.35-mm-diameter cylindrical specimens at strain rates of $10^{-7}$ and $10^{-8} \mathrm{~s}^{-1}$ under crevice and noncrevice conditions. All tests were interrupted after nominal elongation strain of 1-4\%. Scanning electron microscopy revealed some crack initiation in virtually all the materlals, as well as weldments made from these materlals. A stress- or strain-ratio cracking index ranks these materials, in order of increasing resistance to SCC, as follows: Type 304 SS < Type 316L SS < Incoloy $825<\mathrm{Cu}-30 \% \mathrm{NI}<\mathrm{Cu}$ and $\mathrm{Cu}-7 \% \mathrm{Al}$.

Fracture-mechanics CGR tests were conducted on 25.4-mm-thick compact tension specimens of Types 304L and 316L stainless steel (SS) and Incoloy 825. Crack-growth rates were measured under various load conditions: load ratios $(R)$ of $0.5-1.0$. frequencies of $10^{-3}-1 \mathrm{~Hz}$, rise times of $1-1000 \mathrm{~s}$, and peak stress intensities of $25-40 \mathrm{MPa} \cdot \mathrm{m}^{1 / 2}$. The measured CGRs are bounded by the predicted rates from the current ASME Section XI correlation for fatigue CGRs of austenitic stainless steel in air. Environmentally accelerated crack growth was not evident in any of the three materlals under the test conditions investigated. 


\section{Introduction}

\subsection{Objectives}

The objectives of the present program are to (1) determine whether any of the six candidate alloys currently under consideration as waste container materials can survive for 300 years in the Yucca Mountain repository without developing through-w;all stress corrosion cracks, and (2) rank the candidate materials in terms of their resistance to stress corrosion cracking (SCC) in the repository environment. Two types of tests were conducted: (1) slow-strain-rate tests (SSRTs), and (2) crack-growth-rate (CGR) tests based on standard compact tension (CT) fracture-mechanics specimens. In the overall test program, approximately 33 SSRTs were performed on six candidate materials, together with CGR tests on six CT specimens from three candidate materials in simulated waste repository groundwater. This is the final report for the program.

\subsection{Background}

In December 1987, Congress arnended the Nuclear Waste Policy Act of 1982 and designated the Yuc a Mountain site in Southern Nevada as the nation's first high-level nuclear waste repository, if further investigations confirm that it is suitable. Yucca Mountain is located on the southwestern boundary of the Nevada Test Site, and the geologic horizon at the proposed location for the repository is compacted volcanic ash, or tuff, consisting of quartz, christobalite, alkall feldspar, and other minor phases ${ }^{`}$ situated above the permanent water table. Thus, interaction between groundwater and the waste packages should be minimal.

The high-level waste packages consist of three major components: the metallic containment barriers (the contalners or canisters), the waste Itself, and other materials, including packing materials, emplacement-hole liners, etc. The metallic containers are intended to provide essentially complete containment of the nuclear waste for 300 to 1,000 years after emplacement. During the waste isolation or postcontainment period that extends for thousands of years after the metallic containment barriers are breached, the waste itself is expected to control the rate of release of radioactive nuclides into the immediate repository environment. The temperature of the waste package will be sufficiently high for much of the time so that the limited groundwater in the vicinity of the package will be present only in the form of steam. Nonetheless, the proposed tests will focus on aqueous environments at $=93^{\circ} \mathrm{C}$, because these environments are expected to provide deleterious conditions (which may provide the "worst case") for SCC susceptibllity. The elemental composition of Well $\mathrm{J}-13$ groundwater, which is representative of the groundwater present at the Yucca Mountain site, is summarized in Table 1.2

\section{Test Materials}

Six candidate materials are being testerl, namely Type 304L stainless steel (SS). Type 316L SS, Incoloy 825, P-deoxidized Cu (CDA-122), Cu-30\%Ni (CDA-715), and Cu-7\%Al (Al bronze, or CDA-614). ${ }^{3}$ These materials were chosen as candiaates because of their good corrosion properties and their extenstve use in the marine, nuclear, and process industries. ${ }^{4}$ The alloys were obtained from Lawrence Livermore National Laboratory (LLNL) in the annealed condition. 
Table 1. Elemental Composition of Well J-13 Groundwatera

\begin{tabular}{cccc}
\hline Element & $\begin{array}{c}\text { Concentration } \\
\left(\mathrm{mg} \cdot \mathrm{L}^{-1}\right)\end{array}$ & Anion & $\begin{array}{c}\text { Concentration } \\
\left(\mathrm{mg} \cdot \mathrm{L}^{-1}\right)\end{array}$ \\
\hline $\mathrm{Ca}$ & 11.75 & $\mathrm{~F}^{-1}$ & 2.1 \\
$\mathrm{Mg}$ & 1.76 & $\mathrm{Cl}^{-1}$ & 6.4 \\
$\mathrm{Na}$ & 45.0 & $\mathrm{SO}_{4}^{2-}$ & 18.1 \\
$\mathrm{~K}$ & 5.3 & $\mathrm{HCO}_{3}^{-}$ & 143.0 \\
$\mathrm{Ll}$ & 0.06 & $\mathrm{NO}_{3}^{-}$ & 10.1 \\
$\mathrm{Fe}$ & 0.04 & - & - \\
$\mathrm{Mn}$ & 0.001 & - & - \\
$\mathrm{Al}$ & 0.03 & - & - \\
$\mathrm{Si}$ & 30.0 & - & - \\
\hline
\end{tabular}

aDissolved oxygen concentration, $5.7 \mathrm{ppm} ; \mathrm{pH}, 6.9$

The following weldments, fabricated from these base materials by LLNL, are also being tested (the second alloy indicated in each pair is the weld filler metal): Type 304L SS/308L SS. Type 316L SS/316L SS. Incoloy 825/Incoloy 65, Incoloy 825/Inconel 625. $\mathrm{Cu}-30 \mathrm{Ni} / \mathrm{Monel} 67$, and $\mathrm{Cu}-7 \mathrm{Al} / \mathrm{Al}$ bronze Ai2. The weldments were made by the gas-metalarc welding (GMAW) process. In addition, LLNL supplied $\mathrm{Cu}$ and $\mathrm{Cu}-7 \mathrm{Al}$ weldments produced by the electron-beam welding (EBW) process. These latter weldments were produced without filler metal, and the fusion zones are narrow compared with the GMAW weldments.

Elemental compositions of the base and weld filler metals are given in Tables 2-7. and selected mechanical properties provided by vendors are given in Table 8 . The yield strengths of the base materials and weldments were determined independently by Argonne National Laboratory at room temperature and at $93^{\circ} \mathrm{C}$, and these values are presented in Table 9.

\section{Slow-Strain-Rate Tensile Tests}

\subsection{Experimental Procedures}

Fabrication drawings for the SSRT specimens are shown in Figs. 1-3, and the locations of welds in the GMAW and EBW specimens are shown in Figs. 2 and 3. respectively. Similar specimens were used in our earlier studies on SCC of austenitic stainless steels in simulated bolling wicer environments. 5.6 The small-diameter $\quad=0.8-0.9$ $\mathrm{mm}$ ) through-holes localize the strain and cracking, thereby facllitating observation of SCC 
by scanning electron microscopy (SEM). When pins of matching materlais are inserted in the holes, crevices are produced.

The SSRTs were conducted in simulated $\mathrm{J}-13$ water at $93^{\circ} \mathrm{C}$ at strain rates of $10^{-7}$ and $10^{-8} \mathrm{~s}^{-1}$ for the base specimens and were interrupted after elongation (plastic) strains between 1 and $4 \%$. The tests were conducted in a $1.270-\mathrm{L} \mathrm{Ni}$ container. A worm-gear Jactuator, gear reducer, and a variable-speed control system were used to apply the strain. The temperature was maintained by clamp-on heaters with associated instrumentation. A once-through water system with a flow rate of $\approx 3 \mathrm{~mL} / \mathrm{min}$ was used. The SSRT system, including the feedwater system and the electrochemical-potential (ECP) monitoring system, is shoun in Fig. 4.

For tests $\mathrm{W}-1$ through $\mathrm{W}-23$, the flow of simulated $\mathrm{J}-13$ water was maintained by an overpressure in the feedwater tank and the flow rate was controlled by a capillary tube connecting the feedwater tank to the test chamber. After a number of tests, the capillary tube was found to be clogged by the insoluble silicon compounds and bicarbonates. Therefore in tests $\mathrm{W}-23 / \mathrm{W}-33$, a mechanical peristaltic pump was installed in the feedwater line to ensure a more continuous now through the environmental chamber. Also, the water chemistry for the early tests was varied from test to test as various simulations of $\mathrm{J}-13$ water were examined, to avold excessive formation of precipitates at the test temperature. Details of the simulated $J-13$ water chemistry, its characterization. and the procedures for measuring ECP are described in a subsequent section of this report.

For tests W-13/W--33, a dial indicator was connected to the Jactuator to measure the displacement of the pull rod. This measurement, along with measurements of the system compliance, can be used to estimate the strains in the specimen during the test.

Measurements of the total specimen length before and after the tests give even more accurate values of the actual elongation (plastic strain). After each test, the specimen was sectioned by electrical-discharge machining (EDM), as shown in Fig. 5, so that the entire hole region could be examined by SEM at magnifications up to $2000 \mathrm{x}$ to detect stress corrosion cracks. ${ }^{6}$

In tests $W-1$ through $W-7$, pins of a matching material were inserted in the two through-holes to produce crevices. The tests were conducted at a strain rate of $10^{-7} \mathrm{~s}^{-1}$ and were interrupted after elongations of 3-3.7\%. During the tests, the top crevice was exposed alternately to water and vapor, and the bottom crevice was kept immersed in water. Siphon action in the inverted drain tube shown in Fig. 4 exposes the top crevice to alternate liquid and vapor. The bottom crevice is always immersed in liquid. When the hole at the top of the drain tube is opened to the atmosphere, both crevices can be exposed to liquild only.

Tests were also performed on the base materials at a strain rate of $10^{-8} \mathrm{~s}^{-1}$ to investigate the effect of strain rate on SCC. In these tests, one of the holes was left open, but a pin was inserted in the other to produce a crevice. The entire specimen was continuously exposed to the liquid. These changes were made to determine whether a crevice is necessary for cracking of the materials. The tests were interrupted after plastic elongations or strains of $=1.0-1.6 \%$, which are somewhat lower than the strains at which the tests were interrupted at the higher strain rate. Welded specimens were strained at a 
Table 2. Elemental Compositton (wt.\%) of Type 304L Stainless Base Metal and Type 308L Statnless Steel Weld Filler Metala

\begin{tabular}{|c|c|c|c|c|}
\hline \multirow[b]{3}{*}{ Element } & \multicolumn{3}{|c|}{ Nyoc 304L stainless steel } & \multirow{3}{*}{$\begin{array}{c}\text { Type } 3081 \text { SS } \\
\text { Heat K6835 } \\
\text { Vendor }\end{array}$} \\
\hline & \multirow{2}{*}{$\begin{array}{l}\text { Heat V70200 } \\
\text { Vendor }\end{array}$} & \multicolumn{2}{|c|}{ Heas V70312 } & \\
\hline & & Vendor & Independent & \\
\hline C & 0.023 & 0.015 & 0.02 & 0.019 \\
\hline$M n$ & 1.79 & 1.82 & 1.89 & 2.22 \\
\hline $\mathrm{P}$ & 0.03 & 0.03 & 0.024 & 0.015 \\
\hline$s$ & 1.0 .018 & 0.018 & 0.016 & 0.001 \\
\hline si & 0.34 & 0.4 & 0.34 & 0.37 \\
\hline $\mathrm{Cr}$ & 18.15 & $\mid 8.21$ & 19.09 & 18.6 \\
\hline NI & 8.25 & 8.16 & 8.73 & 9.53 \\
\hline o.s & 0.26 & 0.3 & 0.3 & 0.1 \\
\hline Mo & 0.3 & 0.34 & 0.26 & 0.07 \\
\hline Co & 0.14 & 0.15 & - & - \\
\hline N & 0.079 & 0.093 & 0.095 & - \\
\hline 0 & - & - & 0.009 & - \\
\hline
\end{tabular}

a Vendors were Eastem Stainless Steel Company for the Type 304L. SS and American Welding Alloys for the Type $308 \mathrm{~L}$. SS. The Independent analysis was performed by Anamet laboratories. Inc.

Table 3. Elemental Composttion (wt.96) of Type 316L Stainless Steel Base Metal (Heat 16650) and Type 316L Stainless Steel Weld Filler Metal (Heat 4H3367)a

\begin{tabular}{|c|c|c|c|}
\hline \multirow[b]{2}{*}{ Element } & \multicolumn{2}{|c|}{ Heat 16650} & \multirow{2}{*}{$\begin{array}{c}\text { Heat } 4 \mathrm{H} 13367 \\
\text { Vendor }\end{array}$} \\
\hline & Vendor & Independe:ht & \\
\hline c & 0.018 & 0.018 & 0.018 \\
\hline$M n$ & 1.78 & 1.86 & 1.98 \\
\hline$p$ & 0.0265 & 0.022 & 0.023 \\
\hline 3 & 0.013 & 0.016 & 0.018 \\
\hline SI & 0.43 & 0.40 & 0.63 \\
\hline or & 16.5 & 16.84 & 18.69 \\
\hline Ni & $10.3 y$ & 11.1 & 12.29 \\
\hline Mo & 2.09 & 2.1 & - \\
\hline as & 0.10 & 0.17 & 0.25 \\
\hline Co & 0.1 & - & - \\
\hline$N$ & 6.05 .4 & 0.058 & - \\
\hline 0 & - & 0.010 & - \\
\hline
\end{tabular}

a Vendurs were Jessep stect congande for the hase nelial

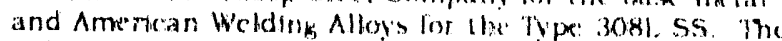
independent anatyous was performed by Aname

Laboritories. Ine 
Table 4. Elemental Composition (wt.\%) of Incoloy 825 Base Metal and Inconel 625 and Incoloy 65 Wield Filler Metala

\begin{tabular}{|c|c|c|c|c|c|}
\hline \multirow[b]{3}{*}{ Element } & \multicolumn{3}{|c|}{ Incoloy 825} & \multirow{3}{*}{$\begin{array}{c}\text { Inconel } 625 \\
\text { Heal } \\
\text { VX045lAY } \\
\text { Vendor }\end{array}$} & \multirow{3}{*}{$\begin{array}{c}\text { Incoloy } 65 \\
\text { Heat } \\
\text { N5OABH } \\
\text { Vendor }\end{array}$} \\
\hline & \multirow{2}{*}{$\begin{array}{l}\begin{array}{c}\text { Heat } \\
\text { HH2 } 125 \mathrm{~F}\end{array} \\
\text { Vendor }\end{array}$} & \multicolumn{2}{|c|}{$\begin{array}{c}\text { Heat } \\
\text { HH3884FG }\end{array}$} & & \\
\hline & & Vendor & Indep't & & \\
\hline C & 0.02 & 0.01 & 0.014 & 0.04 & 0.041 \\
\hline $\mathrm{Mn}$ & 0.39 & 0.46 & 0.47 & 0.07 & 0.43 \\
\hline $\mathrm{Fe}$ & 27.98 & 27.4 & Balance & 4.2 & 28.79 \\
\hline $\mathbf{s}$ & 0.003 & 0.001 & 0.004 & 0.001 & 0.001 \\
\hline SI & 0.14 & 0.31 & 0.33 & 0.19 & 0.18 \\
\hline $\mathrm{Ou}_{1}$ & 2.03 & 2.06 & 1.98 & 0.10 & $1.8 i$ \\
\hline NI & 43.89 & 43.55 & 43.5 & 60.03 & 42.83 \\
\hline $\mathrm{Cr}$ & 21.98 & 22.11 & 22.44 & 22.21 & 22.21 \\
\hline fal & 0.03 & 0.06 & 0.06 & 0.24 & 0.09 \\
\hline $\mathrm{TI}$ & 0.75 & 0.83 & 0.84 & 0.27 & 0.91 \\
\hline Mo & 2.79 & 3.21 & 3.12 & 9.06 & 2.72 \\
\hline $\mathrm{Cb}+\mathrm{Ta}$ & - & 0.36 & 3.58 & - & - \\
\hline $\mathbf{N}$ & - & 0.007 & - & - & - \\
\hline 0 & - & 0.004 & - & - & - \\
\hline$P$ & - & - & 0.010 & 0.017 & - \\
\hline
\end{tabular}

a Vendor was INCO Alloys International for all of these alloys. The independent analysis was performed by Anamet Laboratories, Inc.

Table 5. Elemental Composttion (wt.\%) of Phosphorus-Deoxtdized Coppera

\begin{tabular}{ccccccc}
\hline & \multicolumn{2}{c}{ Heat 7374} & & \multicolumn{2}{c}{ Heat 6653 } \\
\cline { 2 - 3 } \cline { 6 - 6 } Element & Analysis 1 & Analysis 2 & Analysis 1 & Analysis 2 & Independent \\
\hline \multirow{2}{*}{ Ou } & 99.90 & 99.90 & 99.90 & 99.90 & 99.95 \\
$\mathrm{P}$ & 0.039 & 0.039 & 0.027 & 0.030 & 0.032 \\
\hline
\end{tabular}

a Vendor was Revere Copper Products, Inc. for bo h heats of materlali two analyses were provided with each heat. The independent analysis was performed by Anamet Laboratories, Inc. 
Table 6. Elemental Composition (ut.36) of the Cu-30\%Nt Alloy and Monel 67 Weld Filler Metala

\begin{tabular}{|c|c|c|c|c|c|}
\hline \multirow[b]{3}{*}{ Element } & \multicolumn{4}{|c|}{$\mathrm{Cu}-30 \% \mathrm{NI}$} & \multirow{3}{*}{$\begin{array}{c}\text { Monel } 67 \\
\text { Heat N5GABH } \\
\text { Vendor }\end{array}$} \\
\hline & \multirow{2}{*}{$\begin{array}{c}\text { Heat } 673 \\
\text { Vendor }\end{array}$} & \multicolumn{3}{|c|}{ Heat 050} & \\
\hline & & Analys Is I & Anatysis 2 & Independent & \\
\hline ar & 69.52 & 69.73 & 67.96 & 68.1 & 68.51 \\
\hline Ni & 29.4 & 29.3 & 31.0 & 30.7 & 29.72 \\
\hline $\mathrm{Pb}$ & 0.004 & 0.006 & 0.005 & $<0.005$ & $<0.001$ \\
\hline Fe & 0.55 & 0.52 & 0.59 & 0.50 & 0.50 \\
\hline $\mathrm{Zn}$ & 0.03 & 0.03 & 0.03 & 0.09 & - \\
\hline$p$ & 0.001 & 0.001 & 0.001 & $<0.005$ & 0.008 \\
\hline$M n$ & 0.44 & 0.43 & 0.41 & 0.51 & 0.81 \\
\hline C & 0.011 & 0.008 & 0.008 & 0.03 & - \\
\hline S & 0.002 & 0.001 & 0.002 & $<0.005$ & 0.001 \\
\hline $\mathbf{S}_{t}$ & - & - & - & - & 0.1 \\
\hline $\mathrm{TI}$ & - & - & - & - & 0.35 \\
\hline
\end{tabular}

a Vendor was Hussey Copper, Ltd., for both heats of base (two analyses were provided for Hleat 050). INCO Alloys International was the vendor of the Monel 67 weld fuller metal. The independent analysis was performed by Anamet Laboratorles, Inc.

Table. 7. Elemental Composition (wt.\%) of the Aluminum Bronze Base Metal Alloys and Specifications for the Aluminum Bronze Al2 Weld Filler Metala

\begin{tabular}{|c|c|c|c|c|c|c|}
\hline \multirow[b]{3}{*}{ Element. } & \multicolumn{5}{|c|}{ Aluminurn Bronze } & \multirow{3}{*}{$\begin{array}{c}\text { Al Bronze A2 } \\
\text { Heat } \\
\text { K9KO229BA } \\
\text { Vendor }\end{array}$} \\
\hline & \multicolumn{2}{|c|}{ Heal 5485} & \multicolumn{3}{|c|}{ Heat $5263-A$} & \\
\hline & $\begin{array}{l}\text { Analy-- } \\
\text { sts } 1\end{array}$ & $\begin{array}{l}\text { Analy- } \\
\text { sis } 2\end{array}$ & $\begin{array}{l}\text { Analy- } \\
\text { sis I }\end{array}$ & $\begin{array}{l}\text { Analy- } \\
\text { sis } 2\end{array}$ & $\begin{array}{l}\text { Indepen- } \\
\text { dent }\end{array}$ & \\
\hline à & 90.69 & $9 \mathrm{J.76}$ & 90.67 & 90.52 & balance & balance \\
\hline Al & 6.64 & 6.65 & 6.55 & 6.49 & 6.19 & $9.0-11.0$ \\
\hline Fe & 2.41 & 2.23 & 2.42 & 2.63 & 2.97 & $\leq 1.5$ \\
\hline P & 0.001 & 0.001 & - & - & $<0.005$ & - \\
\hline $\mathrm{Zn}$ & - & - & 0.26 & 0.25 & 0.14 & $\leq 0.02$ \\
\hline $\mathrm{Mn}$ & - & - & - & - & 0.09 & - \\
\hline $\mathrm{Pb}$ & - & - & - & - & - & $\leq 0.02$ \\
\hline
\end{tabular}

a Vendor was Willams \& Company. Inc.. for both heats of base meial (two analyses were prowilded for each heat); $J$. W. Harrts Co., was the vendor for the weld metal (Heat K9K02298A). The independent analysls was performed by Anarnet Laboratorles. Inc. 
Table 8. Selected Mechanical Properties of the Experimental Materials ${ }^{a}$

\begin{tabular}{|c|c|c|c|c|c|}
\hline $\begin{array}{l}\text { Material and } \\
\text { Heat No. }\end{array}$ & $\begin{array}{l}\text { Yield } \\
\text { Strength } \\
\text { (MPa) }\end{array}$ & $\begin{array}{l}\text { Tensile } \\
\text { Strength } \\
\text { (MPa) }\end{array}$ & $\begin{array}{c}\text { Total } \\
\text { Elongation } \\
(\%)\end{array}$ & $\begin{array}{c}\text { Reduction } \\
\text { of Area } \\
(\%)\end{array}$ & Hardness \\
\hline \multicolumn{6}{|l|}{ Type 304L SS } \\
\hline V70200 & 273 & 594 & 59 & 66 & HB 156 \\
\hline$V 70312$ & 292 & 614 & 55 & 64 & HB 160 \\
\hline $\begin{array}{c}\text { Type } 316 L \text { sS } \\
16650\end{array}$ & 231 & 530 & 53.9 & 72.0 & BHN 137 \\
\hline \multicolumn{6}{|l|}{$\begin{array}{c}16650 \\
\text { Incoloy } 825\end{array}$} \\
\hline HH2125F & 298 & 676 & 43 & 62 & $R_{B} 85$ \\
\hline HH3884FG & 321 & 712 & 47 & 69 & $R_{B} 83$ \\
\hline \multicolumn{6}{|l|}{ Copper } \\
\hline 6653 & - & 232 & $55-59$ & - & F6I \\
\hline 7374 & - & 220 & - & - & - \\
\hline \multicolumn{6}{|l|}{$\mathrm{Cu}-30 \% \mathrm{NI}$} \\
\hline 050 & 177 & 388 & 45.5 & - & $R_{B} \quad 42-48$ \\
\hline 673 & 177 & 366 & $44-45$ & - & $R_{B} 64-65$ \\
\hline
\end{tabular}

aMechanical properties provided by the vendors.

Tabie 9. Yield Stress of Smooth Base $e^{a}$ and Welded Candidate Waste Container Materials

\begin{tabular}{|c|c|c|c|c|}
\hline Material & $\begin{array}{l}\text { Heat Number } \\
\text { Base/Weld }\end{array}$ & Base & Weldment & $\begin{array}{l}\text { Yteld Stress } \\
\text { (Ks)||MPa| }\end{array}$ \\
\hline $304 L$ SS & V70200 & $x$ & - & $(40.5)|279|$ \\
\hline 3161.55 & 16650 & $x$ & - & $(37.3)|257|$ \\
\hline Incoloy 825 & $\mathrm{H} 2125 \mathrm{~F}$ & $x$ & - & $\mid 50.5)|348|$ \\
\hline as & 7374 & $x$ & - & $(11.4) \quad|79|$ \\
\hline $\mathrm{Cu}-7 \% \mathrm{Al}$ & M5485 & $\mathbf{x}$ & - & $(44.6)|307|$ \\
\hline $\mathrm{Cu}-30 \% \mathrm{NI}$ & 673 & $\mathbf{x}$ & - & $(23.8)|164|$ \\
\hline $304 L$ SS & v70312/w004 & - & $x$ & $(52.8)|364|$ \\
\hline $316 \mathrm{~L}, \mathrm{SS}$ & $16650 / W 002$ & - & $\mathbf{x}$ & $(48.8)|336|$ \\
\hline Incoloy 825 & HH3884FG/W010 & - & $x$ & $(55.3)|381|$ \\
\hline Incoloy 825 & HH3884FG/WOO7 & - & $\mathbf{x}$ & $(55.3)|381|$ \\
\hline Cure & $6653 / 6653$ & - & $\mathbf{x}$ & $(19.5) \quad 1134 \mid$ \\
\hline $\mathrm{Cu}-79\{\mathrm{Al}$ & M5263A/WOLA & - & $x$ & $(44.9) \quad|309|$ \\
\hline $\mathrm{Cu}-796 \mathrm{Al}$ & $M 5263 A / M 5263 A$ & - & $x$ & $(44.9) \quad|309|$ \\
\hline $\mathrm{Cu}-30 \% \mathrm{NI}$ & HFO5O/WOI 3 & - & $x$ & $(23.8)|164|$ \\
\hline
\end{tabular}

Tensile tests on unwelded specimens were performed in air at room temperature at a siraln rate of $2.2 \times 10^{-4} \mathrm{~s}^{-1}$.

hensile tests on weldments were performed in air at $93^{\circ} \mathrm{C}$ at the same strain rate as used for base materials. Yield stress for the weldnent (smoohl specimens are estimated from the yicld stress delernined tor the srroth specimens with holes, taking into account the reduced cross section due to the hole.

These weldments were produced by electron-beam welding: all the other weldments were made ioy gas-meiti-aic welding. 
Table 10. Summary of Experimental Conditions in SSRT Tests

\begin{tabular}{|c|c|c|c|c|c|c|}
\hline $\begin{array}{c}\text { Test } \\
\text { Nurnber }\end{array}$ & $\begin{array}{c}\text { Flow } \\
\text { Control }\end{array}$ & $\begin{array}{l}\text { Pull Rod } \\
\text { Dial } \\
\text { Indicator }\end{array}$ & $\begin{array}{c}\text { Exposure } \\
\text { Conditions }\end{array}$ & $\begin{array}{c}\text { Strain at } \\
\text { Interrupt } \\
(\%)\end{array}$ & $\begin{array}{c}\text { Si Level } \\
\text { In Water } \\
(\mathrm{ppm})\end{array}$ & $\begin{array}{c}\mathrm{HCO}_{3} \text { Level } \\
\text { In Water } \\
\text { (ppm) }\end{array}$ \\
\hline \multicolumn{7}{|c|}{ Base Metal Tests at $\dot{\varepsilon}=10^{-7} \mathrm{~s}^{-1}$} \\
\hline$W-1$ & overpressure & no & 1 & 4.9 & 530 & 622 \\
\hline$W-2$ & overpressure & no & 1 & 3.0 & 30.2 & 78.0 \\
\hline$w^{\prime}-3$ & overpressure & no & 1 & 3.4 & 29.4 & 44.0 \\
\hline$W-4$ & overpressure & no & 1 & 3.7 & 29.6 & 36.0 \\
\hline W-5 & overpressure & no & 1 & 3.7 & 27.6 & 15.0 \\
\hline W-6 & overpressure & no & 1 & 3.6 & 29.1 & 25.0 \\
\hline W-7 & overpressure & no & 1 & 2.9 & 29.2 & 19.0 \\
\hline$W-12^{b}$ & overpressure & no & 1 & 3.1 & $<0.1$ & 128.0 \\
\hline \multicolumn{7}{|c|}{ Base Metal Tests at $\dot{\varepsilon}=10^{-8} \mathrm{~s}^{-1}$} \\
\hline$w \cdot 13$ & overpressure & yes & 4 & 1.2 & - & 137.0 \\
\hline$W \cdot 14$ & overpressure & yes & 4 & 1.3 & - & 125.0 \\
\hline$W-15$ & overpressure & yes & 4 & 1.0 & - & 130.0 \\
\hline$W-18$ & overpressure & yes & 4 & 1.5 & - & 131.0 \\
\hline W- 19 & overpressure & yes & 4 & 1.6 & - & 134.0 \\
\hline$w-20$ & overpressure & yes & 4 & 1.6 & . & 134.0 \\
\hline \multicolumn{7}{|c|}{ Weldment Tests $\left(\hat{\varepsilon}=10^{-7} \mathrm{~s}^{-1}\right)$} \\
\hline W-9 & overpressure & no & 3 & 2.3 & 0.18 & 52.0 \\
\hline W-10 & overpressure & no & 3 & 2.7 & 0.13 & 128.0 \\
\hline W-11 & overpressure & no & 2 & 2.9 & $<0.1$ & 133.0 \\
\hline W-16 & overpressure & yes & 3 & 2.8 & - & 133.0 \\
\hline$W-17$ & overpressure & yes & 3 & 3.0 & - & 133.0 \\
\hline$W-21$ & overpressure & yes & 2 & 3.2 & - & 133.0 \\
\hline W-22 & overpressure & yes & 3 & 3.1 & - & 130.0 \\
\hline \multicolumn{7}{|c|}{ Supplemental Base Metal Tests $\left(\hat{\varepsilon}=10^{-7} \mathrm{~s}^{-1}\right)$} \\
\hline W-23 & pump & yes & 2 & $26.6^{c}$ & - & 133.0 \\
\hline$W-24$ & pump & yes & 2 & 18.2 & - & 137.0 \\
\hline W-26 & purnp & yes & 2 & 5.6 & - & 139.0 \\
\hline W-27 & purnp & yes & 2 & 6.1 & - & 142.0 \\
\hline$W \cdot 28$ & pump & yes & 2 & 5.0 & - & 141.0 \\
\hline W-29 & pump & yes & 2 & 5.5 & - & 140.0 \\
\hline$w-30$ & purnp & yes & 2 & 5.7 & - & 138.0 \\
\hline W-31 & pump & yes & 2 & 5.6 & - & 135.0 \\
\hline W-32 & pump & yes & 2 & 11.93 & - & 134.0 \\
\hline W-33 & pump & yes & 2 & 11.88 & - & 134.0 \\
\hline \multicolumn{7}{|c|}{ Supplemental Weldment Test $\left(\varepsilon=10^{-7} \mathrm{~s}^{-1}\right)$} \\
\hline$w-25$ & purnp & yes & 2 & 3.2 & - & 141.0 \\
\hline
\end{tabular}

$a_{1}=$ two holes, two pins: one hole exposed continuously to liquid: the other alternately to liquid and vapor.

$2=$ two holes, two pins: both holes exposed continuously to liquid.

$3=$ three holes, three pins: all holes exposed continuously to liquid.

$4=$ two holes, one pin: both holes exposed continuously to liquid.

b Repeat of invalid test W.8.

c Test run to fallure. 


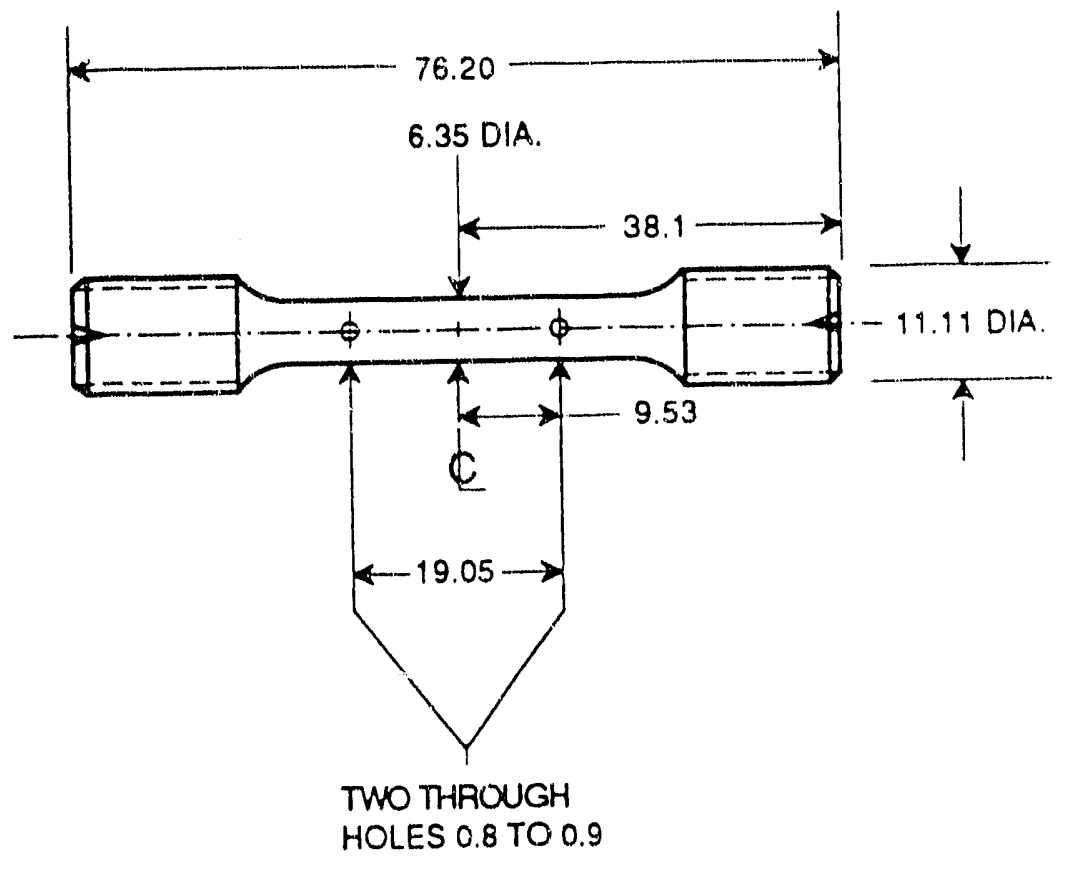

Fig. 1. Fabrication Drawing for Base Metal SSRT Spectmen. Dimensions are in $\mathrm{mm}$.

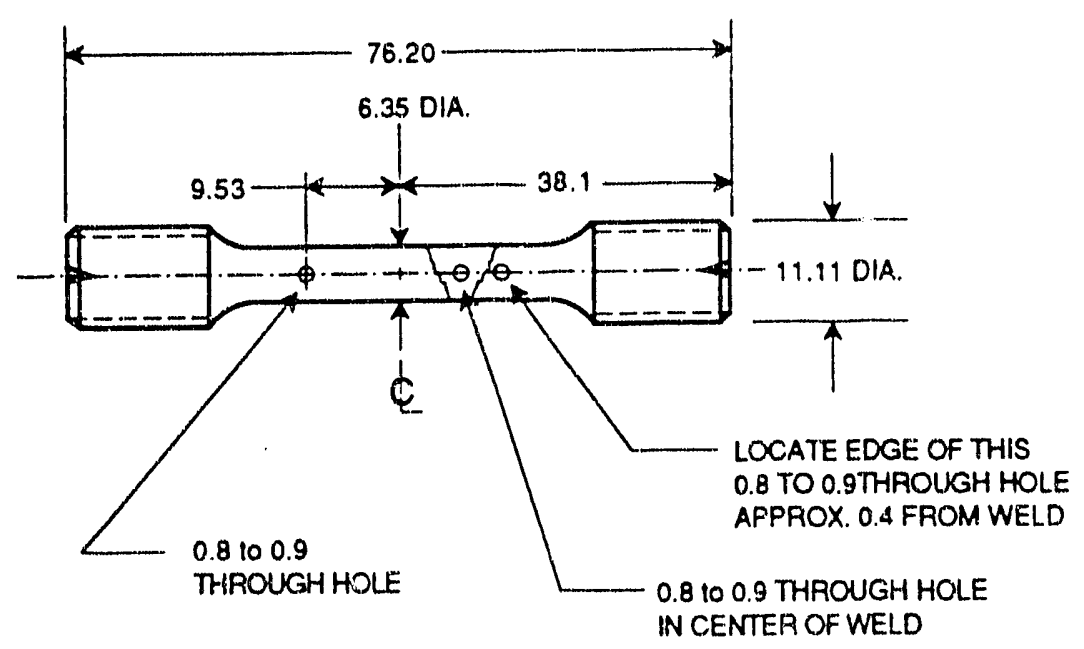

Fig. 2. Fabrication Drawing for Gas-Metal-Arc Welded Specimen. Dimensions are in $\mathrm{mm}$. 


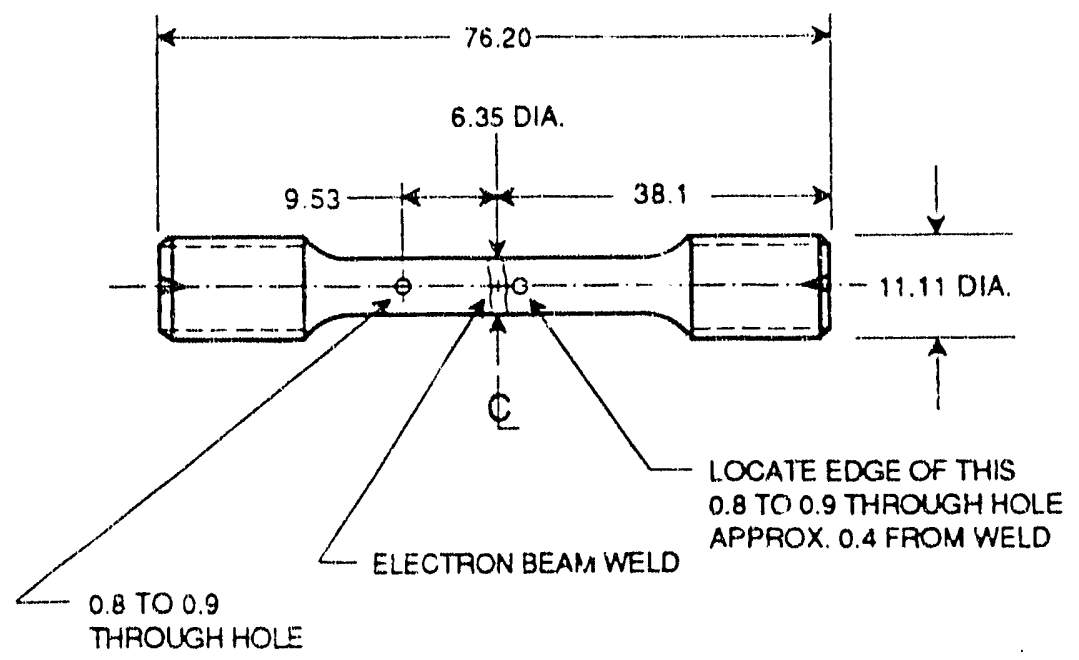

Fig. 3. Fabrication Drawing for Electron-Beam-Welded Specimen. Dimensions are in $\mathrm{mm}$.

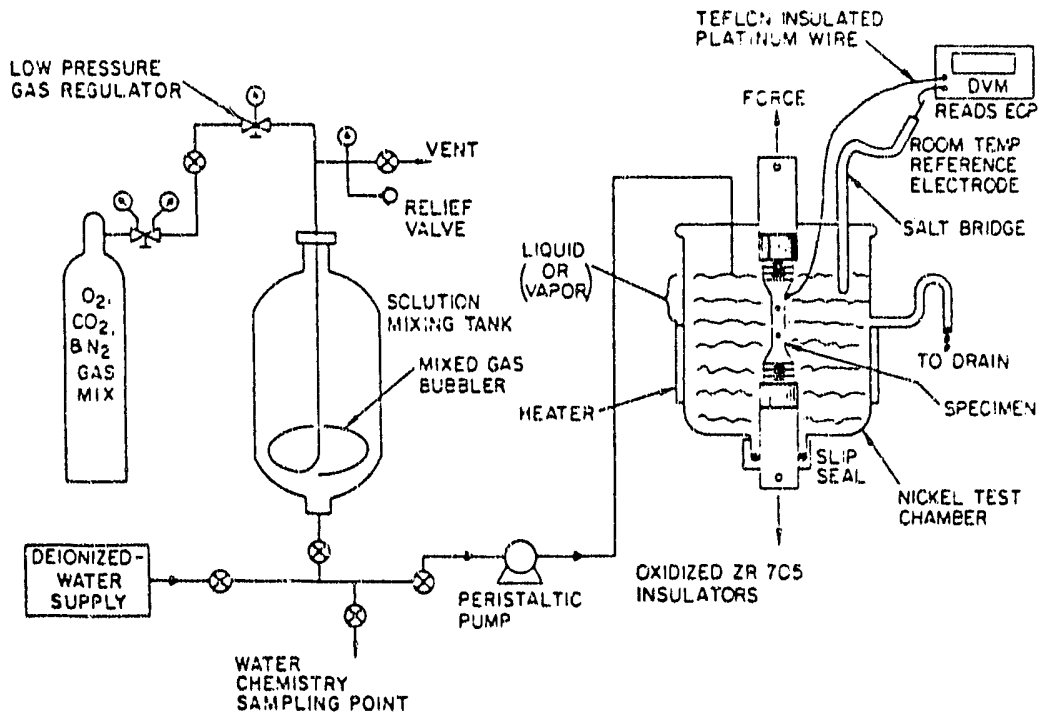

Fyg. 4. Schematic of SSRT Setup with Feedwater and Electrochemical Potential Monttoring Systems. 


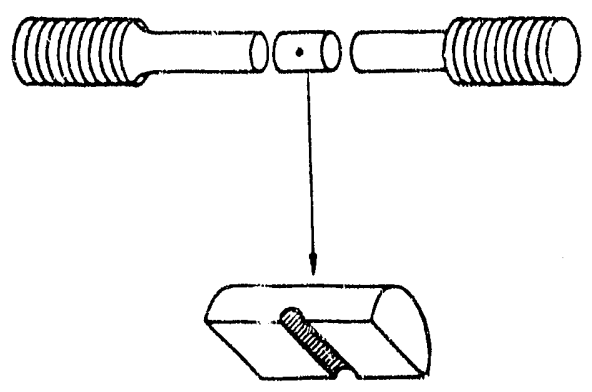

Fig. 5. Cross-Sectional View of Drilled Hole in SSRT specimen

rate of $10^{-7} \mathrm{~s}^{-1}$ and interrupted after elongations of $2.3-3.2 \%$. In the tests on weld specimens, all of the crevices were continuously immersed in water.

It should be pointed out that in the series of tests conducted at the two strain rates, namely, $10^{-7}$ and $10^{-8} \mathrm{~s}^{-1}$. different exposure conditions were used. In the tests conducted at the faster strain rate (tests $w-1 / w-7)$, pins were inserted in both holes of the specimen (two crevices). Only one of the holes was exposed continuously to liquid: the other was exposed alternately to liquid and vapor phases. In addition, the water chemistry for the first test $(W-1)$ was vastly different from the rest of the tests. In the tests conducted at the slower strain rate of $10^{-8} \mathrm{~s}^{-1}$, the water chemistry is not comparable to that used for the tests conducted at the faster strain rates. Also, in the slower strain rate tests, only one of the holes was left open (noncrevice), and a pin was inserted in the other to produce a crevice. Both holes were continuously exposed to simulated J-13 water. Because of these differences in test conditions, the strain-rate effects observed in this work should be regarded as very preliminary.

The varying experimental conditions for the SSRT tests are summarized in Table 10. These differences should be borne in mind when reviewing the test results.

\subsection{SSRT Results (Tests W-1/W-22)}

\subsubsection{Observations of SCC by SEM}

The SSRT results for the initial base metal tests are summarized in Tables 11 and 12 for the weldment tests in Table 13. The SEM observations for all the tests conducted at a strain rate of $10^{-7} \mathrm{~s}^{-1}$ are summarized in Tables 14 and 15 . The results of the initial base metal and weldment tests show some craciking in virtually all the specimens, including those tested at the slower strain rate of $10^{-8} \mathrm{~s}^{-1}$. However, in most cases, crack 
observations were made at magnifications as high as $1000-2000 \mathrm{x}$, because it was difficult to observe well-defined cracks at magnifications lower than $100 x$. Hence, the actual crack depths inferred from the size of the crack opening are umall (in the micron range) even for Type 304L SS. These findings are consistent with our unsuccessful efforts thus far to observe cracks $>10-20 \mu \mathrm{m}$ in depth in the transverse metallographic specimens of Type 304L SS. The cracks in Type 304L SS are more open (and hence are probably deeper) than those in Incoloy 825, as shown in Fig. 6. This is consistent with the expected increased resistance of Incoloy 82,5 to SCC because of its higher Ni content. However, Incoloy 825 shows a larger number of cracks than Type 304 SS.

The cracks in Incoloy 825 , which appear to have initiated at machining marks that are favorably oriented for cracking, appear as thin straight lines in Figs. 6 and 7 . It is not clear whether the larger number of cracks in the Incoloy 825 is due to the machining marks. Such straight marks are also frequently seen in specimens of other materials, although they were not observed in our earlier studies on SCC of austenitic stainless steels. 5,6 These machining marks are attributed to the use of a slightly modified drilling procedure that was adopted after completing 25 tests. However. this change in procedure was not found to affect the stress/strain response of the materials in the simulated J-13 water environment.

For the Incoloy 825 weldment, where the base metal is a different heat, poor surface finish made it difficult to determine whether cracks were present in the base metal, as shown in Figs. 7a and 7c. The filler matertal, however, showed pronounced cracking (Fig. 7b).

Scanning electron microscopy of the $\mathrm{Cu}$ and $\mathrm{Cu}$-base alloy spccimens reveals that these materials also showed some signs of cracking in simulated $s-13$ water. As shown in Fig. 8, there is no discernible difference in cracking among the three Cu-based materials. Cracking in $\mathrm{Cu}$ (Fig. 8a) and in $\mathrm{Cu}-30 \mathrm{Ni}$ (Fig. 8c) occurred both at the mac'ining marks (which are nearly straight) and elsewhere (cracks with wavy appearance). On the basis of these observations, it appears that the differences in SCC susceptibility of the three Cubased materials are small compared to those, for example, between Type 304L SS and Incoloy 825. Further quantification of SCC in terms of crack depth and growth rate is required to better delineate differences in cracking behavior.

Cracking has also been observed in all the weldments tested. For example. the Type 316L SS weldment with matching filler metal shows cracking both in the weld and base material (Fig. 9). The Cu-30Ni weldment specimen also exhibited cracking, and there was no clear-cut difference in the appearance of cracks in the base, weld, and heat-affected zone (Fig. 10).

The cracking behavior of the crevices continuously exposed to liquid was not much different from that of crevices alternately exposed to liquid and vapor during the tests. This is illustrated in Fig. 11 for an Incoloy 825 specimen. It also appears that a crevice is not required for SCC to occur in these materials. As shown in Fig. 12, the cracking at holes with and without pins appears similar for Incoloy 825 and $\mathrm{Cu}-30 \mathrm{Ni}$. On the basis of SEM observations. It is also difficult to determine whether the change in strain rate had any effect on cracking. because the observed differences are small and the tests performed 
Table 11. SSRT Results for Candidate Container Materials (two holes with pins inserted in each at a Strain Rate of $10^{-7} \mathrm{~s}^{-1}$ in Simulated $\mathrm{J}-13$ water at $93^{\circ} \mathrm{C}$

\begin{tabular}{lccccccc}
\hline $\begin{array}{l}\text { Test } \\
\text { Number }\end{array}$ & Material & $\begin{array}{c}\text { Heat } \\
\text { Number }\end{array}$ & $\begin{array}{c}\text { Specimen } \\
\text { ECP. } \\
(\mathrm{mVISHE})\end{array}$ & $\begin{array}{c}\text { Elongation } \\
\varepsilon_{\mathrm{p}}(\%)\end{array}$ & $\begin{array}{c}\text { Local } \\
\text { Straina } \\
(\%)\end{array}$ & $\begin{array}{c}\text { Nominal } \\
\text { Stress } \\
\text { Ratio }\end{array}$ & $\begin{array}{c}\text { Nominal } \\
\text { Strain } \\
\text { Ratio }\end{array}$ \\
\hline W1 & IN 825 & H2125F & 233 & 4.9 & 15.1 & 0.93 & 0.82 \\
W2 & IN 825 & H2125F & 253 & 3.0 & 8.1 & 0.94 & 0.83 \\
W3 & Cu-30Ni & 673 & - & 3.4 & 9.0 & 0.96 & 0.87 \\
W4 & $304 \mathrm{~L}$ & V70200 & 310 & 3.7 & $d$ & 0.80 & 0.19 \\
W5 & Ca & 7374 & 303 & 3.7 & 15.2 & 0.99 & 1.00 \\
W6 & $316 L$ & 16650 & 268 & 3.6 & $d$ & 0.81 & 0.51 \\
W7 & Cu-6Al & M5485 & 323 & 2.9 & 8.6 & 1.00 & 1.07 \\
W12 & Cu & 7374 & 308 & 3.1 & 10.1 & 0.91 & 0.78 \\
\hline
\end{tabular}

aThe local strain is computed as the product of a strain concentration factor $K_{\mathcal{\varepsilon}}$, estimated from Neuber's rule, and the nominal strain in the unreduced gauge section, which is determined from the stress-strain curve and the measured load on the specimen. $K_{\varepsilon}$ depends on the materlal and strain level.

bsee Eq. 13.

'See Eq. 17.

dToo low to estimate accurately.

Table 12. SSRT Results for Candidate Container Matertals (two holes, one with a pin and one without) at a Stratn Rate of $10^{-8} \mathrm{~s}^{-1}$ in Simulated J-13 Water at $93^{\circ} \mathrm{C}$

\begin{tabular}{lccccccc}
\hline $\begin{array}{l}\text { Test } \\
\text { Number }\end{array}$ & Material & $\begin{array}{c}\text { Heat } \\
\text { Number }\end{array}$ & $\begin{array}{c}\text { Specimen } \\
\text { ECP } \\
\text { (mVISHE]) }\end{array}$ & $\begin{array}{c}\text { Elongation } \\
(\%)\end{array}$ & $\begin{array}{c}\text { Local } \\
\text { Strain } \\
(\%)\end{array}$ & $\begin{array}{c}\text { Nominal } \\
\text { Stress } \\
\text { Ratio }\end{array}$ & $\begin{array}{c}\text { Nominal } \\
\text { Strain } \\
\text { Ratioc }\end{array}$ \\
\hline W13 & IN 825 & H2125F & 383 & 1.2 & d & 0.87 & 0.40 \\
W14 & Cu-30N1 & 673 & 293 & 1.3 & 2.3 & 0.97 & 0.88 \\
W15 & Cu-6Al & M5485 & 268 & 1.0 & 4.5 & 1.01 & 1.15 \\
W18 & O4 & 7374 & 273 & 1.5 & 4.4 & 0.75 & 0.83 \\
W19 & $316 L$ & 16650 & 374 & 1.6 & $d$ & 0.72 & 0.15 \\
W20 & $304 \mathrm{~L}$ & V70200 & 343 & 1.6 & $\mathrm{~d}$ & 0.52 & - \\
\hline
\end{tabular}

a The local strain is computed as the product of a strain concentration factor $\mathrm{K}_{6}$, estimated from Neuber's rule, and the nominal strain in the unreduced gauge section. which is determined from the stress-strain curve and the measured load on the specimen. $K_{\varepsilon}$ depends on the material and strain level.

b See Eq. 13.

c See Eq. 17.

d Too low to measure accurately. 
Table 13. SSRT Results on Weldment Specimens of Candidate Container Materials at a Strain Rate of $10^{-7} \mathrm{~s}^{-1}$ in Simulated $\mathrm{J}-13$ Water at $93^{\circ} \mathrm{C}$

\begin{tabular}{|c|c|c|c|c|c|}
\hline $\begin{array}{l}\text { Test } \\
\text { Number }\end{array}$ & Material & $\begin{array}{c}\text { ID }^{\text {a Number }} \\
\text { Base } \\
\text { Weld }\end{array}$ & $\begin{array}{c}\text { Specimen } \\
\text { ECP } \\
\text { (mV[SHE }])\end{array}$ & $\begin{array}{c}\text { Nominal } \\
\text { Elongation } \\
(\%)\end{array}$ & $\begin{array}{l}\text { Stress } \\
\text { Ratiob }^{\text {b }}\end{array}$ \\
\hline$w-9$ & $\begin{array}{c}\text { Incoloy } \\
825\end{array}$ & $\begin{array}{c}\text { HH3884FG } \\
\text { W010 }\end{array}$ & 290 & 2.3 & 0.95 \\
\hline$w-11$ & $\mathrm{Or}$ & $\begin{array}{l}6653 \\
\text { W019 }\end{array}$ & 283 & 2.9 & 0.89 \\
\hline W-10 & $\mathrm{Cu}-30 \mathrm{NI}$ & HFO5O & 238 & 2.7 & 0.91 \\
\hline$w-17$ & $316 \mathrm{~L}$ & $\begin{array}{l}16650 \\
\text { W002 }\end{array}$ & 363 & 3.0 & 0.98 \\
\hline$w-16$ & $\mathrm{Cu}-7 \mathrm{Al}$ & $\begin{array}{c}\text { 5263-A } \\
\text { W014 }\end{array}$ & 294 & 2.8 & 1.2 \\
\hline$w-21$ & $\mathrm{Cu}-7 \mathrm{Al}$ & $\begin{array}{l}\text { 5263-A } \\
\text { W020 }\end{array}$ & 241 & 3.2 & 1.2 \\
\hline$w-22$ & $\begin{array}{c}\text { Incoloy } \\
825\end{array}$ & $\begin{array}{c}\text { H3884FG } \\
\text { W007 }\end{array}$ & 316 & 3.1 & 1.1 \\
\hline$w-25$ & $304 \mathrm{~L}$ & $\begin{array}{l}\text { v70200 } \\
\text { w004 }\end{array}$ & 334 & 3.2 & 0.97 \\
\hline
\end{tabular}

aID=Identification; Base and weld materials are identified by heat number and weld number, respectively.

bSee Eq. 13.

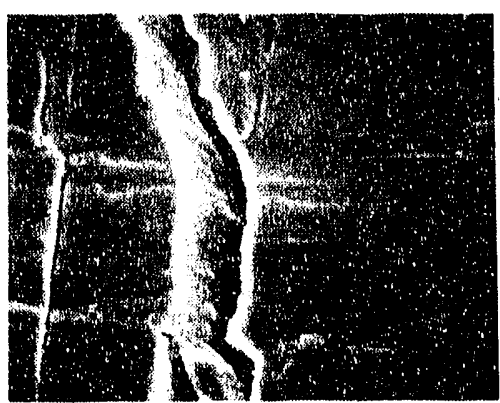

a

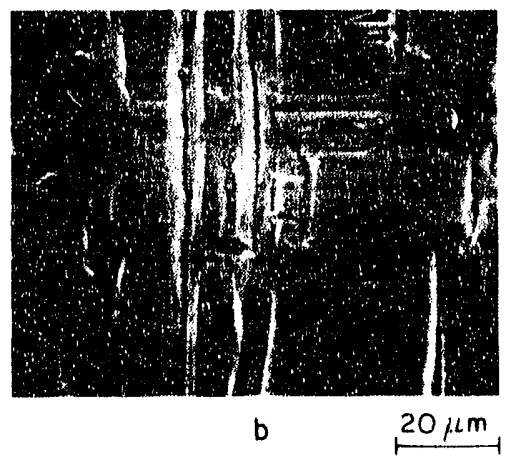

Fig. 6. SEM Photomicrographs of Hole Regions (with Pins) of (a) Type 304L SS, Interrupted after $\varepsilon_{p}=3.7 \%$, and (b) Incoloy 825 Interrupted after $\varepsilon_{p}=3.0 \%\left(\dot{\varepsilon}=1 \times 10^{-7} \mathrm{~s}^{-1}\right)$. 
Table 14. SEM Observations ${ }^{a}$ on SSRT Specimens ${ }^{b}$ of Candidate Waste Container Base Materials Tested in Simulated J-13 Water at $93^{\circ} \mathrm{C}$

\begin{tabular}{|c|c|c|c|c|}
\hline Test No. & Material & Heat No. & Location & $\begin{array}{l}\text { Cracking } \\
\text { Observed }\end{array}$ \\
\hline W1 & Incoloy 825 & $\mathrm{H} 2125 \mathrm{~F}$ & $\begin{array}{c}\text { Top } \\
\text { Bottom }\end{array}$ & $\begin{array}{l}\text { yes } \\
\text { yes }\end{array}$ \\
\hline W2 & Incoloy 825 & $\mathrm{H} 2: 25 \mathrm{~F}$ & $\begin{array}{c}\text { Top } \\
\text { Bottom }\end{array}$ & $\begin{array}{l}\text { yes } \\
\text { yes }\end{array}$ \\
\hline W3 & $\mathrm{Cu}-30 \% \mathrm{Ni}$ & 673 & $\begin{array}{c}\text { Top } \\
\text { Bottom }\end{array}$ & $\begin{array}{l}\text { yes } \\
\text { yes }\end{array}$ \\
\hline W4 & $304 \mathrm{~L}$ SS & V70200 & $\begin{array}{c}\text { Top } \\
\text { Bottom }\end{array}$ & $\begin{array}{l}\text { yes } \\
\text { yes }\end{array}$ \\
\hline W' & $\mathrm{Ou}$ & 7374 & $\begin{array}{c}\text { Top } \\
\text { Bottom }\end{array}$ & $\begin{array}{l}\text { yes } \\
\text { yes }\end{array}$ \\
\hline w6 & $316 \mathrm{~L} \mathrm{SS}$ & 16650 & $\begin{array}{c}\text { Top } \\
\text { Bottom }\end{array}$ & $\begin{array}{l}\text { c } \\
\text { c }\end{array}$ \\
\hline W7 & $\mathrm{Cu}-6 \% \mathrm{Al}$ & M5485 & $\begin{array}{c}\text { Top } \\
\text { Bottom }\end{array}$ & $\begin{array}{l}\text { yes } \\
\text { yes }\end{array}$ \\
\hline W 12 & Ou & 7374 & $\begin{array}{c}\text { Top } \\
\text { Bottom }\end{array}$ & $\begin{array}{l}\text { yes } \\
\text { ves }\end{array}$ \\
\hline
\end{tabular}

a All tests were conducted at a strain rate of $10^{-7} \mathrm{~s}^{-1}$ and interrupted after nominal strains of 3-4\%. SEM observations were made at magnifications between $100 x$ and $2000 x$.

$b$ The specimen has two holes with pins of the same material inserted into them to produce tight crevices. The specimen was exposed to J-13 water In such a way that the top hole with the pin was alternately exposed to water in liquid and vapor phases. but the bottom hole was always immersed in $\mathrm{J}-13$ water.

c This specimen was pulled to failure in liquid nitrogen following the interrupted test to determine the feasibility of determining the crack length. but it was not possible to examine the extent of cracking on the fracture surface.

at the slower strain rate $10^{-8} \mathrm{~s}^{-1}$ were interrupted at lower strains than those performed at a strain rate of $10^{-7} \mathrm{~s}^{-1}$ (see Tables 11 and 12 ).

\subsubsection{Estimation of Local Plastic Strains}

To relate the observed crack initiation and growth to plastic strain, it is necessary to estimate the local plastic strain at the hole. The local strain is computed as the product of a strain concentration factor $K_{e}$, estimated from Neuber's rule, and the nominal strain in the unreduced gage section. which is determined from the stress/strain curve and the measured load on the specimen. 
Table 15. SEM Observations ${ }^{a}$ on SSRT Specimens ${ }^{b}$ of Candidate Container Weldment Specimens Tested in Simulated j-13 Water at $93^{\circ} \mathrm{C}$

\begin{tabular}{|c|c|c|c|c|}
\hline Test No. & Material & Heat No. & Location & $\begin{array}{l}\text { Cracking } \\
\text { Observed }\end{array}$ \\
\hline w9 & $\begin{array}{l}\text { Incoloy } 825 \\
\text { Incoloy } 65\end{array}$ & $\begin{array}{l}\text { HH3884FG } \\
\text { Weld WO10 } \\
\text { HH3884FG }\end{array}$ & $\begin{array}{l}\text { HAZ } \\
\text { Weld } \\
\text { Base }\end{array}$ & $\begin{array}{c}\text { yes } \\
\text { yes } \\
\text { no }\end{array}$ \\
\hline W10 & $\mathrm{Cu}-30 \% \mathrm{Ni}$ & $\begin{array}{c}\text { HF050 } \\
\text { Weld WO13 } \\
\text { HF050 }\end{array}$ & $\begin{array}{l}\text { HAZ } \\
\text { Weld } \\
\text { Base }\end{array}$ & $\begin{array}{l}\text { yes } \\
\text { yes } \\
\text { yes }\end{array}$ \\
\hline W11 & $\begin{array}{c}\mathrm{Cuc} \\
6653\end{array}$ & $\begin{array}{l}6653 \\
\text { Base }\end{array}$ & $\begin{array}{l}\text { HAZ } \\
\text { yes }\end{array}$ & no \\
\hline W16 & $\mathrm{Cu}-7 \% \mathrm{Al}$ & $\begin{array}{c}\text { M5263A } \\
\text { Weld WO14 } \\
\text { M5263A }\end{array}$ & $\begin{array}{l}\text { HAz } \\
\text { Weld } \\
\text { Base }\end{array}$ & $\begin{array}{l}\text { yes } \\
\text { yes } \\
\text { yes }\end{array}$ \\
\hline W17 & 316L SS & $\begin{array}{c}16650 \\
\text { weld WOO2 } \\
16650\end{array}$ & $\begin{array}{l}\text { HAZ } \\
\text { Weld } \\
\text { Base }\end{array}$ & $\begin{array}{l}\text { yes } \\
\text { yes } \\
\text { yes }\end{array}$ \\
\hline W21 & $\mathrm{Cu}-7 \% \mathrm{Al}^{\mathrm{c}}$ & $\begin{array}{l}\text { M5263A } \\
\text { M5263A }\end{array}$ & $\begin{array}{l}\text { HAZ } \\
\text { Weld }\end{array}$ & $\begin{array}{l}\text { yes } \\
\text { yes }\end{array}$ \\
\hline w22 & $\begin{array}{l}\text { Incoloy } 825 \\
\text { Inconel } 625\end{array}$ & $\begin{array}{l}\text { HH3884FG } \\
\text { Weld WOO7 } \\
\text { HH3884FG }\end{array}$ & $\begin{array}{l}\text { HAZ } \\
\text { Weld } \\
\text { Base }\end{array}$ & $\begin{array}{l}\text { yes } \\
\text { yes } \\
\text { yes }\end{array}$ \\
\hline
\end{tabular}

a All tests were conducted at a strain rate of $10^{-7} \mathrm{~s}^{-1}$ and interrupted after nominal strains of $3-4 \%$. SEM observations were made at magnifications between $100 \mathrm{x}$ and $2000 \mathrm{x}$.

b Except for the electron-beam-welded specimens, each specimen had three holes located as shown in Fig. 2. Each hole had a pin inserted into it. The electron-beam-welded specimen has two holes with pins. The specimens were completely immersed in simulated $\mathrm{J}-13$ water during testing.

c Electron-beam-welded.

Stress/strain data for these materials can be described by the frequently used Ramberg and Osgood equation 7

$$
\varepsilon=\frac{\sigma}{E}+\alpha\left(\frac{\sigma}{E}\right)^{m} .
$$

where $\sigma$ and $\varepsilon$ are the nomiral stress and strain, respectively, $E$ is the Young's modulus, and $\mathrm{a}$ and $\mathrm{m}$ are constants. Locally, near the hole, the stress and strain are then given by 


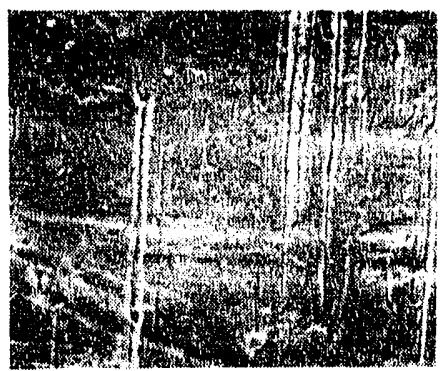

a

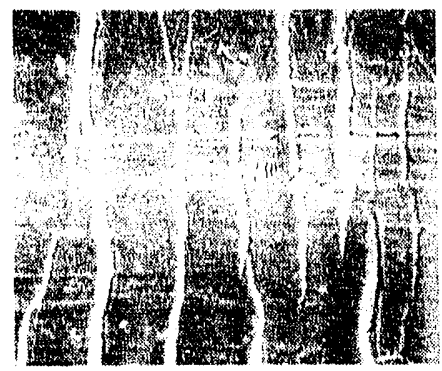

b

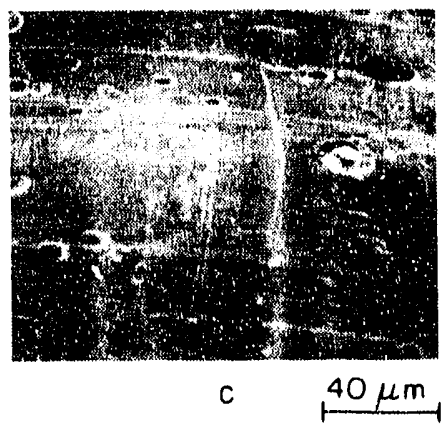

Fig. 7. SEM Photomicrographs of Hole Regions (with Pins) of Welded Incoloy 825 Interrupted after $\varepsilon_{p}=2.3 \%$ : (a) Base, (b) Weld, and (c) HeatAffected Zone $\left(\dot{\varepsilon}=1 \times 10^{-7} \mathrm{~s}^{-1}\right)$

$$
\mathrm{K}_{\varepsilon} \varepsilon=\frac{\sigma \mathrm{K}_{\sigma}}{\mathrm{E}}+\alpha\left(\frac{\sigma \mathrm{K}_{\sigma}}{\mathrm{E}}\right)^{\mathrm{m}}
$$

where $K_{\mathcal{E}}$ and $K_{\sigma}$ are the strain and stress concentration factors, respectively. Substitution of Neuber's rule 8

$$
\mathrm{K}_{\varepsilon}=\frac{\mathrm{K}^{2}}{\mathrm{~K} \sigma}
$$

(where $\mathrm{K}$ is the theoretical elastic stress concentration factor) in Eq. 2 gives

$$
\frac{\mathrm{K}^{2}}{\mathrm{~K}_{\sigma}}=\frac{\varepsilon_{\mathrm{e}} \mathrm{K}_{\sigma}}{\varepsilon_{\mathrm{e}}+\varepsilon_{\rho}}+\mathrm{K}_{\sigma}^{\mathrm{m}} \alpha \frac{\varepsilon_{\mathrm{e}}^{\mathrm{m}}}{\varepsilon_{\mathrm{e}+} \varepsilon_{\mathrm{p}}}
$$



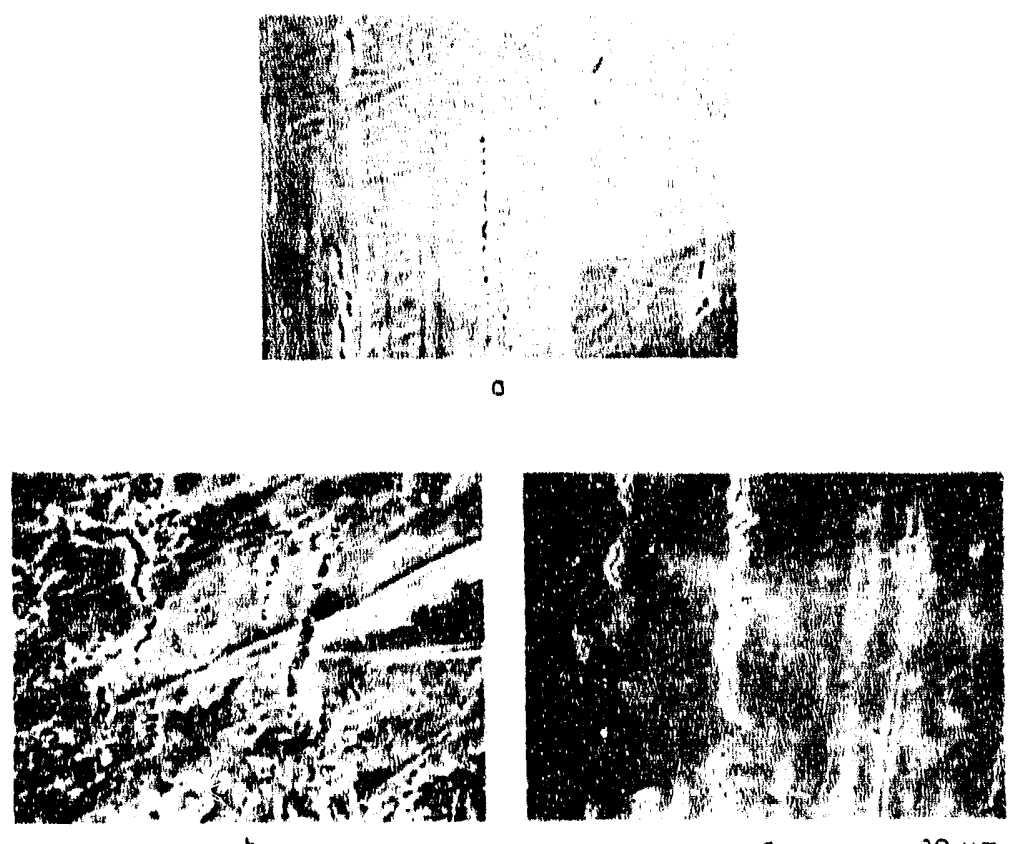

b

c

$20 \mu \mathrm{m}$

Fig. 8. SEM Photomicrographs of Cracks in Hole Regions (with Pins) of $\mathrm{Cu}$ and $\mathrm{Cu}$-Base Alloys: (a) $\mathrm{Cu}$ Interrupted after $\varepsilon_{p}=3.7 \%$, (b) $\mathrm{Cu}-6 \% \mathrm{Al}$ Interrupted after $f_{p}=2.9 \%$, and (c) $\mathrm{Cu}-30 \% \mathrm{Nt}$ Interrupted after $\varepsilon_{p}=3.4 \%\left(\dot{\varepsilon}=1 \times 10^{-7} \mathrm{~s}^{-1}\right)$.

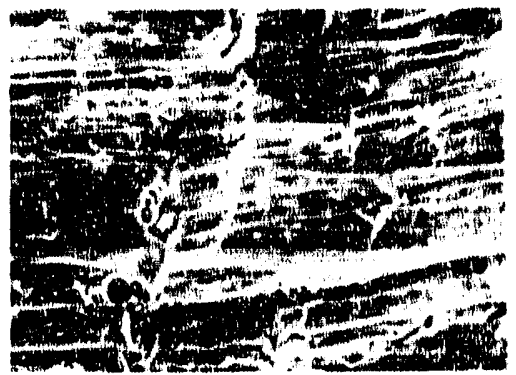

a

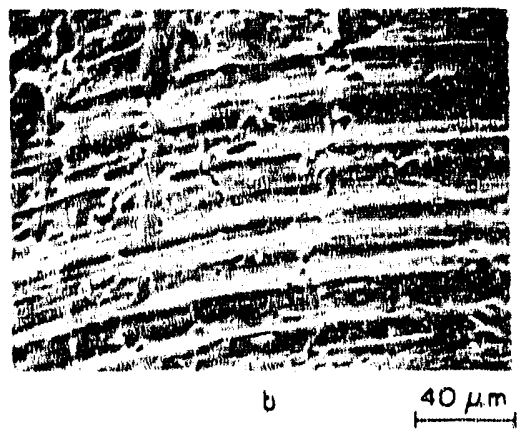

b)
$40 \mu \mathrm{m}$

FYg. 9. SEM Photomicrographs of Cracks in Hole Regions (with Pins) of Welded Type 316L SS Intertupted after $\varepsilon_{p}=3.0 \%$ : (a) Base, and (b) Weid $\left(\varepsilon=1 \times 10^{-7} s^{-1}\right)$. 


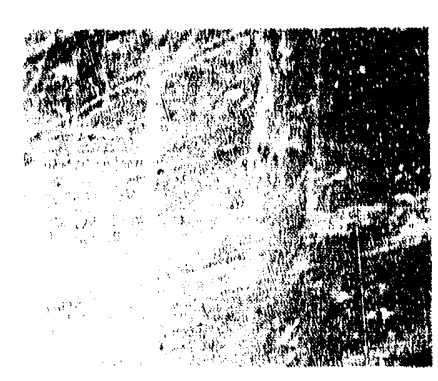

o

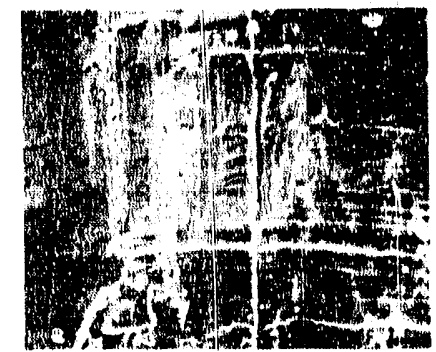

b

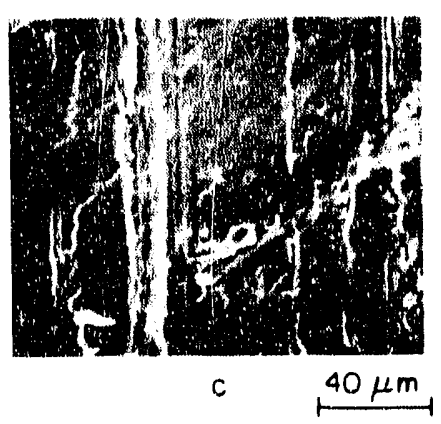

Fig. 10. SEM Photomicrographs of Cracks in Hole Regions (with Pins) of Welded Type $316 \mathrm{~L}$ SS Interrupted after $\varepsilon_{p}=3.0 \%$ : (a) Base, and (b) Weid and( $\left.\dot{\varepsilon}=1 \times 10^{-7} \mathrm{~s}^{-1}\right)$.

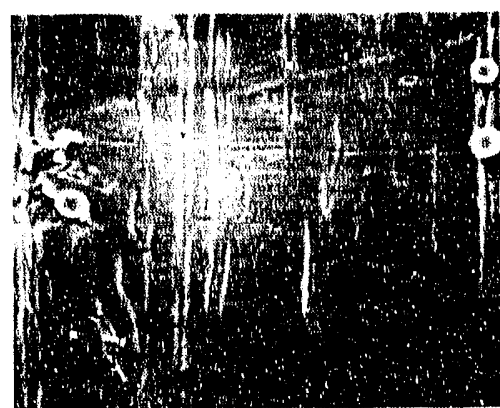

0

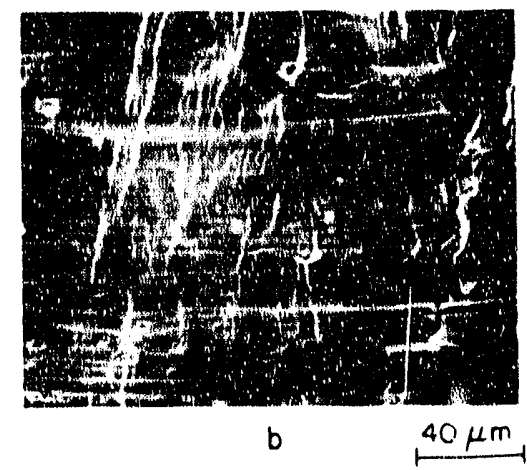

Fig. 11. SEM Photomicrographs of Hole Regtons of Incoloy 825 Interrupted after $\varepsilon_{p}=3.0 \%$ : (a) Exposed to Liquid, and (b) Exposied Altemately to Liquid and Vapor $\left(\dot{\varepsilon}=1 \times 10^{-7} \mathrm{~s}^{-1}\right)$. 


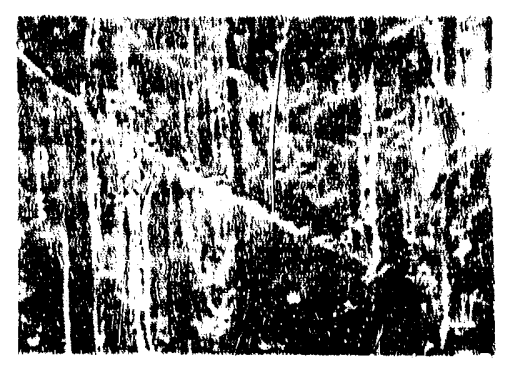

o

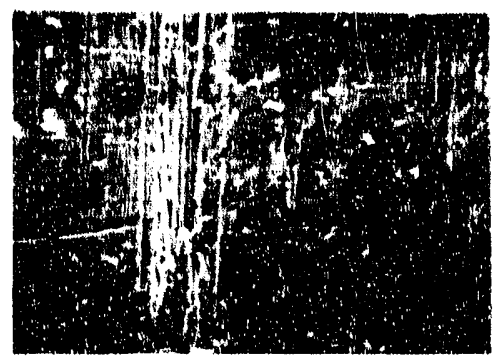

$c$

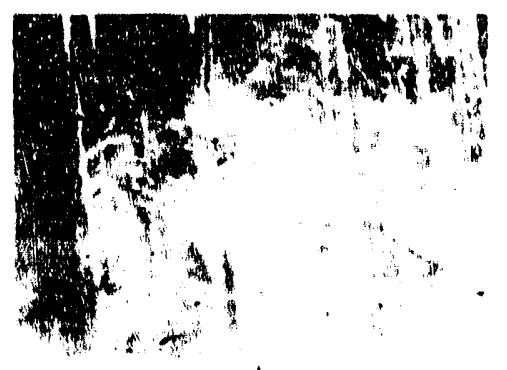

b

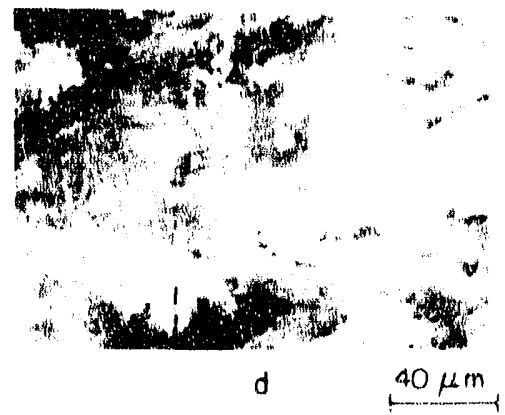

Fig. 12. SEM Photomicrographs of Hole Reglons: (a) Incoloy 825, Hole with Pin, Interrupted after $\varepsilon_{p}=$ 1.2\%. (b) Incoloy 825, Hole without Pin. Interrupted after $\varepsilon_{p}=1,2 \%$, (c) Cu-30\%Nt, Hole with $P\left(n, \varepsilon_{p}=1.3 \%\right.$, and (d) $\mathrm{Cu}-30 \% N$, Hole without Pin, Intertupted after $\varepsilon_{p}=1.3 \%$ (E $\left.=1 \times 10^{-7} \mathrm{~s}^{-1}\right)$.

Rewriting Eq. 1 in the following form:

$$
\varepsilon_{p}=\alpha \varepsilon_{c}^{m}
$$

(where $e_{p}=e-s / E$ ) and substituting Eq. 5 in Eq. 4 yields

$$
K^{2}=K_{\sigma}^{2}\left(\frac{\varepsilon_{c}}{\varepsilon_{c}+\varepsilon_{\rho}}\right)+K_{\sigma}^{m+1}\left(\frac{\varepsilon_{\rho}}{\varepsilon_{e}+\varepsilon_{p}}\right)
$$

Equation 6 can also be expressed as

$$
K^{2}=K_{\sigma}^{2}\left(\frac{\beta}{1+\beta}\right)+K_{\sigma}^{n+1}\left(\frac{1}{1+\beta}\right) .
$$

where $\beta=\varepsilon_{c} / \varepsilon_{p}$. Because $K$ is known (for the SSRT specimen containing a through-hole $K$ $\approx 3)$. Eq. 7 can be solved with the smooth-specimen stress/strain data to estimate the 
actual stress concentration factor $k_{0}$ at the hole. The actual strain concentration can then be determined by using Neuber's rule (Eq. 3).

Stress/strain curves were determined for all the matertals from conventional tenslie tests in alr at a strain rate of $=4.7 \times 10^{-4} \mathrm{~s}^{-1}$. These stress/strain data were analyzed by the Ramberg and Osgood equation and Neuber's rule to determine the straln concentration at the hole as a function of plastic strain. As can be seen from Figs. 13 and 14, the results for $\mathrm{Cu}$ and Type 316L SS show that the strain concentration factor decreases with plastic strain, as expected.

Strain concentration $K_{\ell}$ can also be computed by applying a simple power law relation between stress and plastic strain, namely,

$$
\sigma=\frac{E}{\alpha^{n}} \varepsilon_{p}^{n}=\sigma o \varepsilon_{p}^{n}
$$

where $n=\frac{1}{m}$ and $\sigma_{0}=\frac{E}{\alpha^{n}}$. Locally, near the hole.

$$
K_{\sigma} \sigma=\sigma_{\sigma}\left(K_{\varepsilon} \varepsilon_{p}\right)^{n}
$$

Equations 8 and 9 imply that

$$
\mathbf{K}_{\boldsymbol{\sigma}}=\mathbf{K}_{\varepsilon}^{\mathrm{n}}
$$

Substituting Eq. 10 in Neuber's rule, Eq. 3.

$$
K^{2}=K_{\varepsilon}^{n+1}
$$

and solving for $K_{\mathfrak{f}}$.

$$
\mathrm{K}_{\varepsilon}=\mathrm{K}^{2 /(1+n)}
$$

The two approaches for estimating $\mathrm{K}_{\boldsymbol{E}}$ gtve almost identical results even for relatively low plastic strains, as lllustrated in Figs, 13 and 14.

The local strains in Tables 11 and 12 are computed under the assumption that the stress/strain data generated at $=4.7 \times 10^{-4} \mathrm{~s}^{-1}$ at room temperature can be applied to the SSRT results at a much slower strain rate and at a slightly higher temperature. The nominal strain in the unreduced section is determined from the stress/strain curve corresponding to the load at which the SSRTs were interrupted. The strain concentration factor is determined from Eq. 12 with a value of $n$ approprtate for the strain in the tests. The local plastic strains ranged from 8.1 to $15.2 \%$ for the tests at the strain rate of $10^{-7} \mathrm{~s}^{-1}$ (Table 11$)$ and are lower $(2.3-4.5 \%)$ for tests conducted at the strain rate of $10^{-8} \mathrm{~s}^{-1}$ (Table 12). 


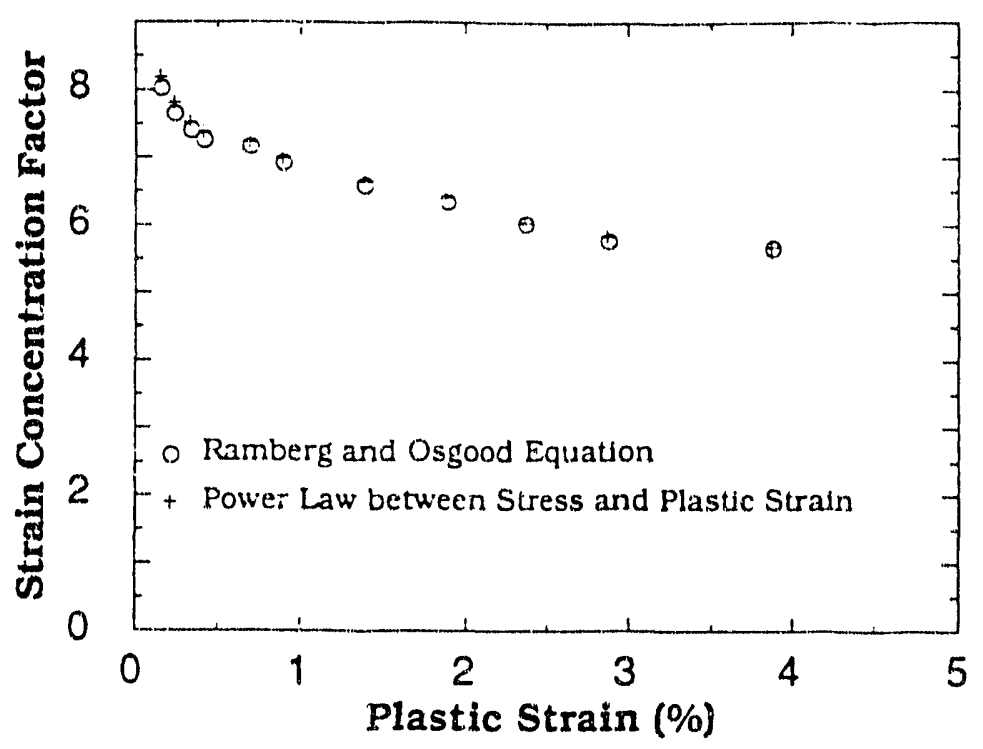

Fig. 13. Strain Concentration Factor as a Function of Plastic Strain for $\mathrm{Cu}$

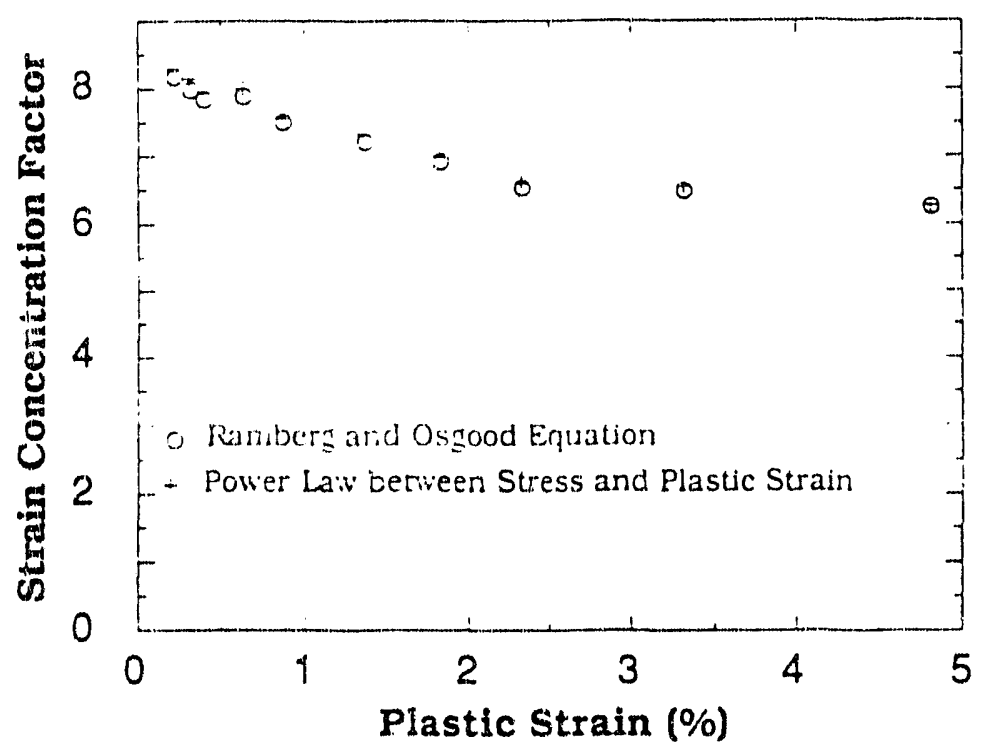

Fg. 14. Strain Concentration as a Function of Plastic Strain for Type 316L SS. 


\subsubsection{Relative SCC Suscepilbility of Waste Container Materials}

To obtain additional information on the relative cracking susceptibility of the various materials, the load-deformation behavior of the specimen during the SSRT test was analyzed, and a cracking index parameter or stress ratio (SR) was formulated by comparing the stress in the environment with that in air at the same plastic strain. For the present geometry. the SR, which characterizes the effect of the environment on the capability of materlal to sustain load in the plastic range, can be defined as

$$
S R=\left(\frac{\sigma_{\mathrm{en}}-\sigma_{\mathrm{y}} / 3}{\sigma_{\mathrm{adr}}-\sigma_{\mathrm{y}} / 3}\right)_{\varepsilon_{\mathrm{p}}}
$$

where $\sigma_{e n}$ is the nominal stress in the environment, $\sigma_{\text {air }}$ is the nominal stress in air evaluated at the same plastic strain, and $\sigma_{y}$ is the yield stress of the material (see Table 9). To minimize geometry effects, $\sigma_{e n}$ and $\sigma_{\text {air }}$ are determined for the same specimen geometry. Local plastic yielding is assumed to occur when the nominal stress reaches $\sigma_{y} / 3$, because the stress concentration factor for the present specimen geometry is $\approx 3$. The use of stress instead of load eliminates any possible differences resulting from variations in specimen diameter. The SR focuses on the changes in stress after plastic yielding, because SCC is not expected without plastic deformation. By eliminating the elastic contribution to stress, the SR appears to provide a sensittve indicator of SCC and is useful for screening materials, at least qualitattvely. As currently computed, we assume that the differences in strain rate between the in-air and SSRT values do not significantly affect the stress/strain response at the temperature of interest. With no cracking. $S R=1$, and if the material is susceptible to cracking, the value is $<1$. However, a measured value of 1 may indicate only that the degree of cracking is so small that the change in loads cannot be detected. Although values of $\mathrm{SR}<1$ indicate that cracking has occurred, tests at different strain rates are needed to determine whether the cracking is environmentally assisted.

To determine the SR, the strains in the SSRT must be known. By measuring the pull-rod displacement during the test, we can determine the strains in "real time" by finding the compliance of the SSRT machine and then using the measured compliance to compute the strain from the measured loads and displacements, as is done in a conventional tensile test. Because the pull-rod displacement measurements were not made for the first 13 tests, "post-test" estimates can instead be obtained from the measured final plastic strain and load at the time of interruption of the tests. The total strain at the end of the test Efinal is then

$$
\varepsilon_{\text {final }}=\varepsilon_{\text {p(final })}+\frac{\sigma_{\text {final }}}{E} \text {. }
$$

where the stress is computed from the final load and the initial cross section of the specimen. The total strain of the specimen as a function of time, e(t), is computed by assuming a consiant strain rate $\dot{\varepsilon}$.

$$
\varepsilon(t)=\varepsilon_{\text {final }}-\dot{\varepsilon}\left(t_{\text {final }}\right) \text {. }
$$

The plastic strain as a function of time, $\varepsilon p(t)$, is then 


$$
\varepsilon_{p}(t)=\varepsilon(t)-\frac{\sigma(t)}{E}
$$

Calibration tests show that the assumption of a constant strain rate is quite good, once yielding has occurred. Thus, plastic strains greater than $\approx 0.5 \%$ may be accurately determined.

Figure 15 shows the variation of SR with plastic strain at a strain rate of $10^{-7} \mathrm{~s}^{-1}$ for the six materials in $\mathrm{J}-13$ water at $93^{\circ} \mathrm{C}$. The ranking of materials in order of increasing resistance to cracking is Type 304L SS < Type 316L SS < Incoloy 82.5 and $\mathrm{Cu}-30 \mathrm{NI}<\mathrm{Cu}$ and $\mathrm{Cu}-7 \mathrm{Al}$. Thus, $\mathrm{P}$-deoxidized $\mathrm{Cu}$ and $\mathrm{Al}$ bronze appear to be more resistant to cracking than the other alloys. The higher cracking resistance of Incoloy 825 relative to Type 304L SS can be attributed to the higher Ni content of Incoloy 825 and is qualitatively consistent with SEM observations of the cracks. The differences in cracking behavior of Incoloy 825 . $\mathrm{Cu}-30 \mathrm{Ni}, \mathrm{Cu}$, and $\mathrm{Cu}-7 \mathrm{Al}$ are small, a finding that is also qualitatively consistent with the SEM observations. Also, the SR appears to be fairly sensittve to cracking even when the cracks are too small to be readily observed metallographically.

It is clear that a greater change in stress/strain response in the environment than in air is produced in the more SCC-susceptible Type 304L SS than in the more resistant Incoloy $\mathbf{8 2 5}$ or copper and its alloys. A difference is also observed in the stress/straln behavior of the smooth specimen and the specimen with two holes in alr; this is qualitatively consistent with the behavior expected from a reducition in cross-sectional area. For example, an 0.8-0.9 $\mathrm{mm}$ through-hole in the gauge section causes a reduction in area of $\approx 20 \%$. But the difference between stress/strain response of the specimen with holes and that with holes and cracks cannot be explained on the basis of a reduction in area because the enlargement of the holes due to observed cracking is small. Therefore it is possible that part of the shift in stress/strain curve of the specimen in the environment relative to that in air can be attributed to the difference in strain rates used for tests in air and tests in the environment, at least for Type 304L, which is known to exhibit anelastic effects at low temperature. ${ }^{9}$

A strain ratio analogour to the SR can be defined:

$$
\left(\frac{\varepsilon_{\mathrm{p}(\text { alr })}}{\varepsilon_{\mathrm{p}(\mathrm{en})}}\right) \sigma^{\prime}
$$

where the strain in air and in the environment are evaluated at the same nominal stress. As i an be seen from Fig. 16, the SCC susceptibility rankings determined from the two ratio: ire similar. However, the strain ratio Indicates a greater degree of susceptibility for Type $304 \mathrm{~L}$ SS, relative to Type 316L SS, than is suggested by the SR. Values of the strain ratio at the erd of the tests are included in Tables 11 and 12. 


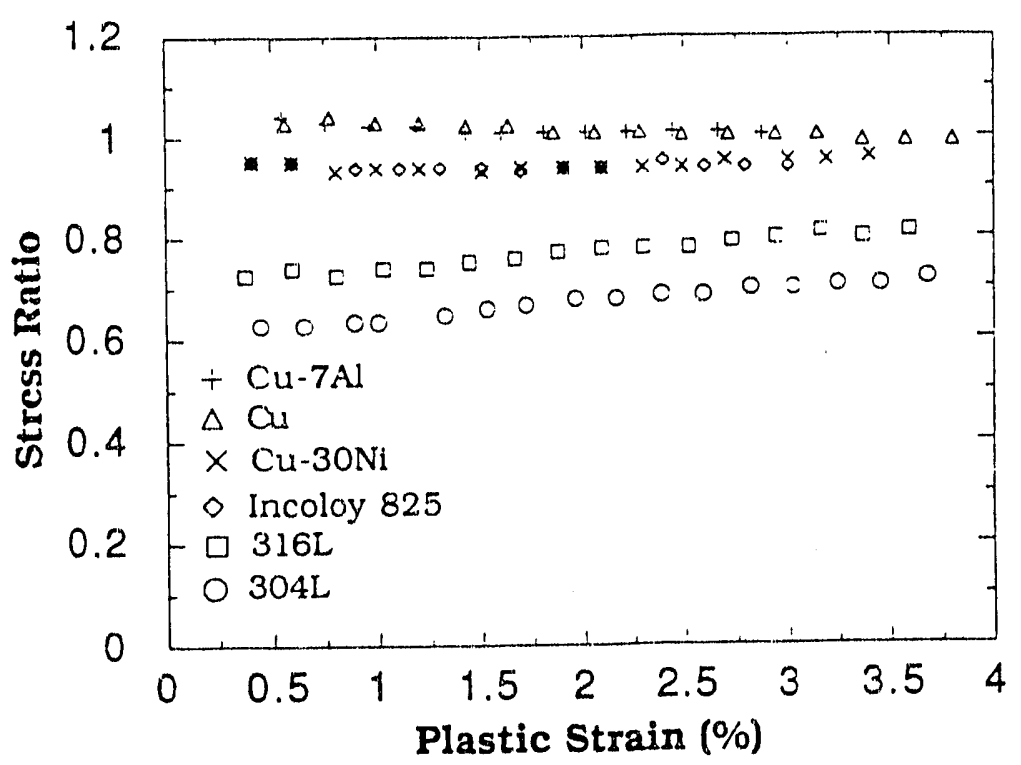

Fy. 15. Relative Cracking Susceptibility of Six Candidate Materials in Simulated Well $\mathrm{J}-13$ Water at $93^{\circ} \mathrm{C}$. Cracking susceptibility is expressed in terms of the nominal stress ratio [Eq. (13)] where lower values imply greater cracking susceptibility $\left(\dot{\varepsilon}=1 \times 10^{-7} \mathrm{~s}^{-1}\right)$.

\subsubsection{SCC Susceptibility of Weldment Specimens}

The results of SSRTs on weldment specimens of several materials are summarked in Table 12. The variation of SR with plastic strain or elongation for Types 304L SS and 316L SS, Incoloy 825, $\mathrm{Cu}$, and $\mathrm{Cu}-30 \mathrm{Ni}$ (Figs. 17-21) suggests that welding has a more deleterious effect on the cracking of $\mathrm{Cu}$ and $\mathrm{Cu}-30 \mathrm{NI}$ than on that of the austenitic alloys. Because the heats of the base materials used in the fabrication of the Incoloy 825. Cu, and $\mathrm{Cu}-30 \mathrm{Ni}$ weldments were different from those used for the unwelded specimens, it is necessary to clarify the role of heat-to-heat differences in these tests compared with differences associated with welding. The SEM observations of the base metal used in the unwelded specimen (Fig. 11a) and the heat of the base metal used in the weldment (Fig. 7a) show different cracking behavior, possibly associated with heat-to-heat variation. As is shown in Fig. 22, the SR suggests that Incoloy 825 with the filler material Inconel 625 is more resistant to cracking than is a similar weldment with the filler material Incoloy 65. The composition of the latter is similar to that of Incoloy 825 . Anomalous behavior has been observed for Al bronze weldments produced by both GMAW and EBW. In these cases. the observed SR is greater than 1 (Fig. 23), and further work is necessary to explain this unexpected behavior. 


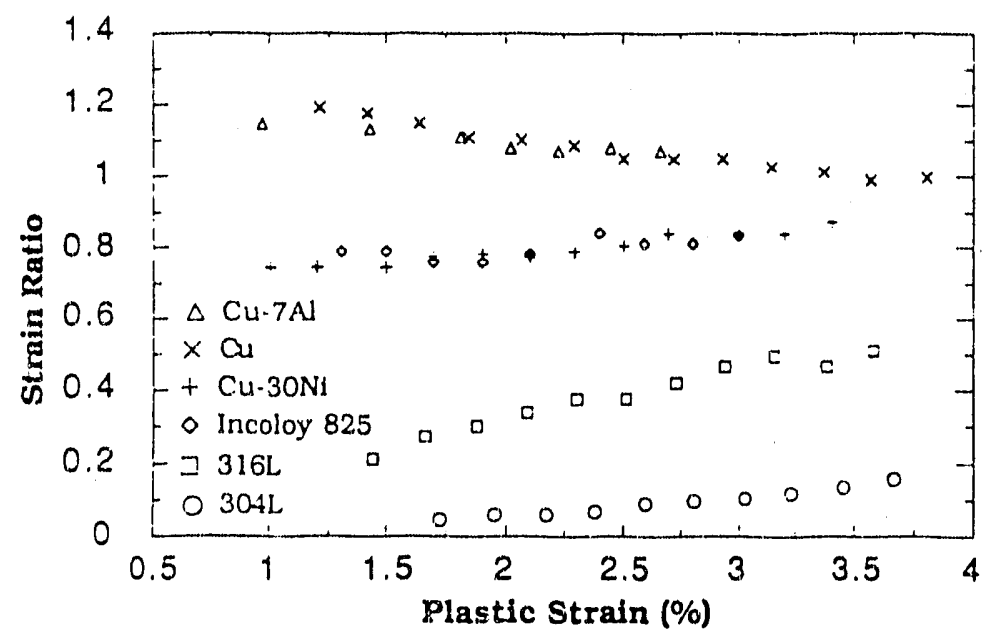

Fig. 16. Relative Cracking Susceptibility of Six Candidate Materials in Simulated Well $J-13$ Water at $93^{\circ} \mathrm{C}$. Cracking susceptibility ts expressed in terms of nominal strain ratio [Eq. (17)] where lower values imply greater cracking susceptibility $\left(\dot{\varepsilon}=1 \times 10^{-7} \mathrm{~s}^{-1}\right)$.

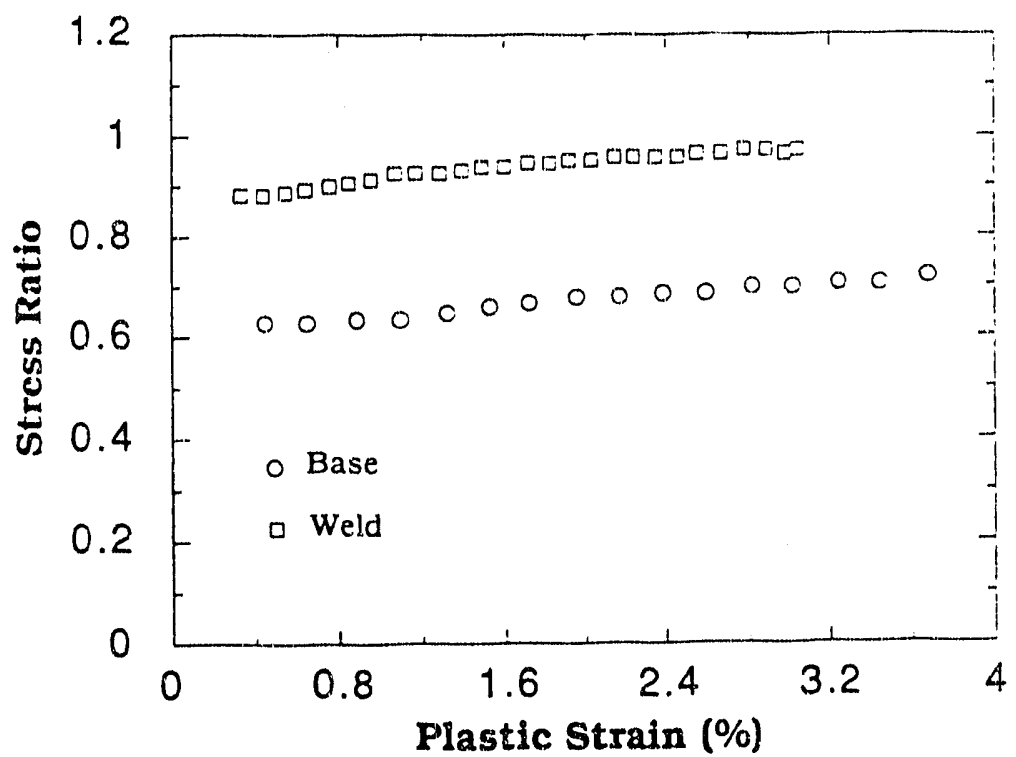

Fig. 17. Comparison of SCC Susceptlbility of Type 304L SS Base Metal and Weldment Spectmens in Stmulated $J-13$ Water at $93^{\circ} \mathrm{C}\left(\varepsilon=1 \times 10^{-7} \mathrm{~s}^{-1}\right)$ 


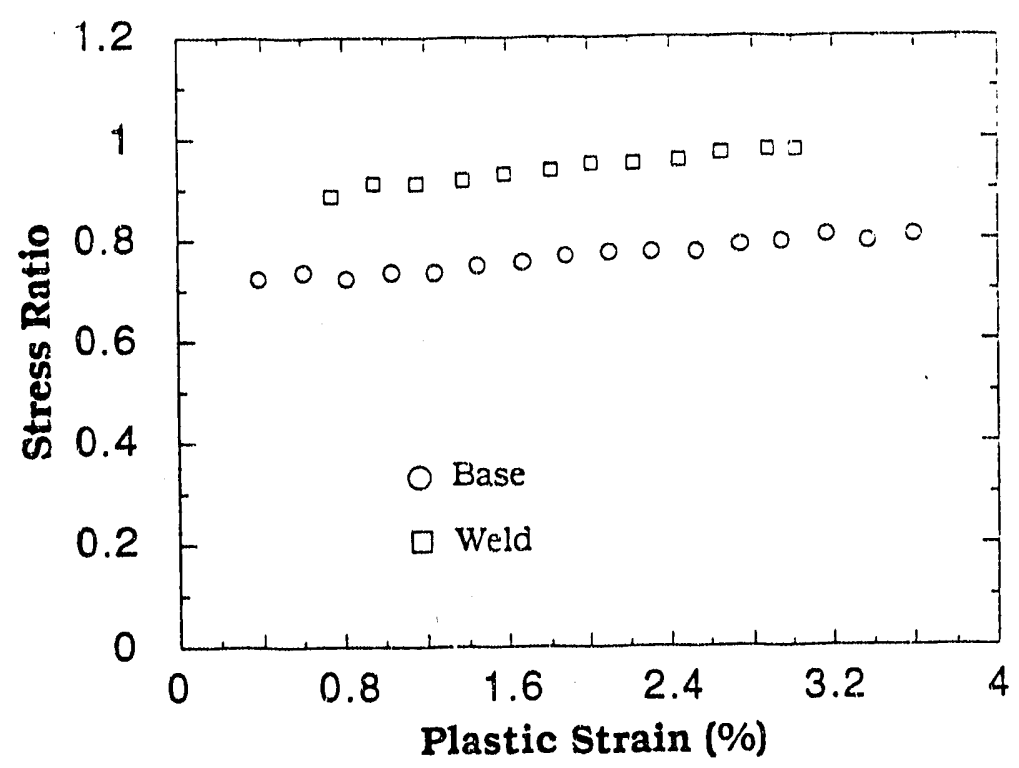

Fig. 18. Comparison of SCC Susceptibilty of Type 316L SS Base Meial and Weldment Specimens in Simuiated $\mathrm{J}-13$ Water at $93^{\circ} \mathrm{C}\left(\varepsilon=1 \times 10^{-7} \mathrm{~s}^{-1}\right)$

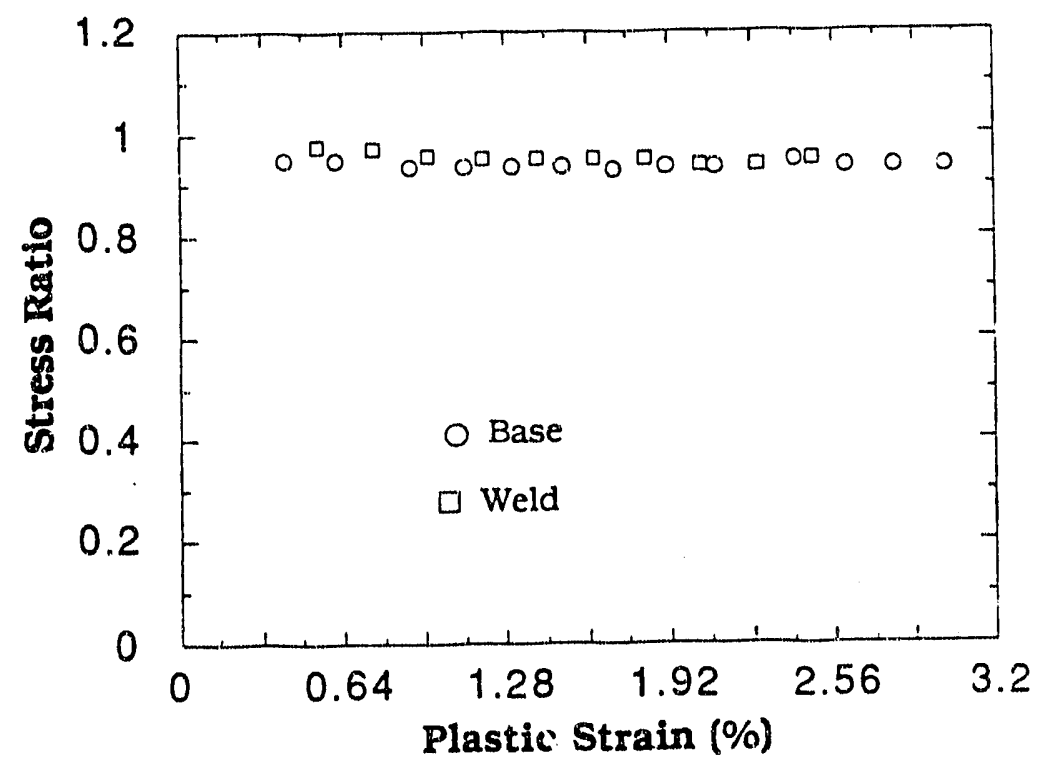

Fig. 19. Comparison of SCC S1.scepttbility of Incoloy 825 Base Metal and Weldment Spectmens in Simulated $J-13$ Water at $93^{\circ} \mathrm{C}\left(\hat{\varepsilon}=1 \times 10^{-7} \mathrm{~s}^{-1}\right)$ 


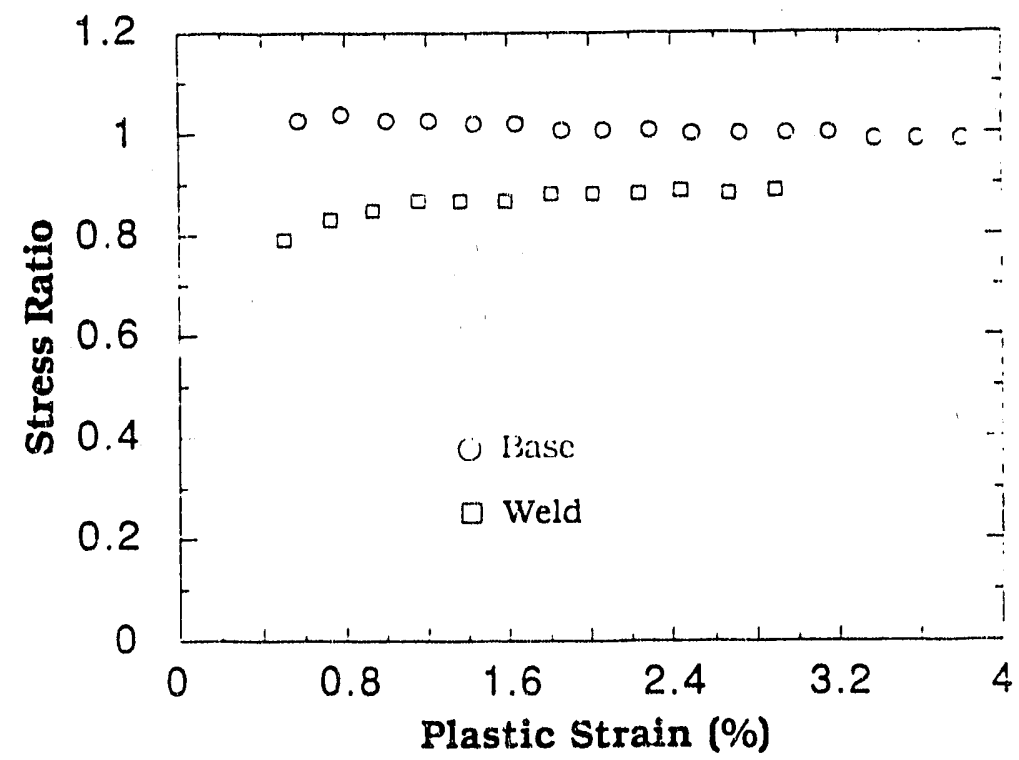

Fig. 20. Compartson of SCC Susceptibility of Cu Base Metal and Weldment Specimens in Simulated $J-13$ Water at $93^{\circ} \mathrm{C}\left(\dot{\varepsilon}=1 \times 10^{-7} \mathrm{~s}^{-1}\right)$

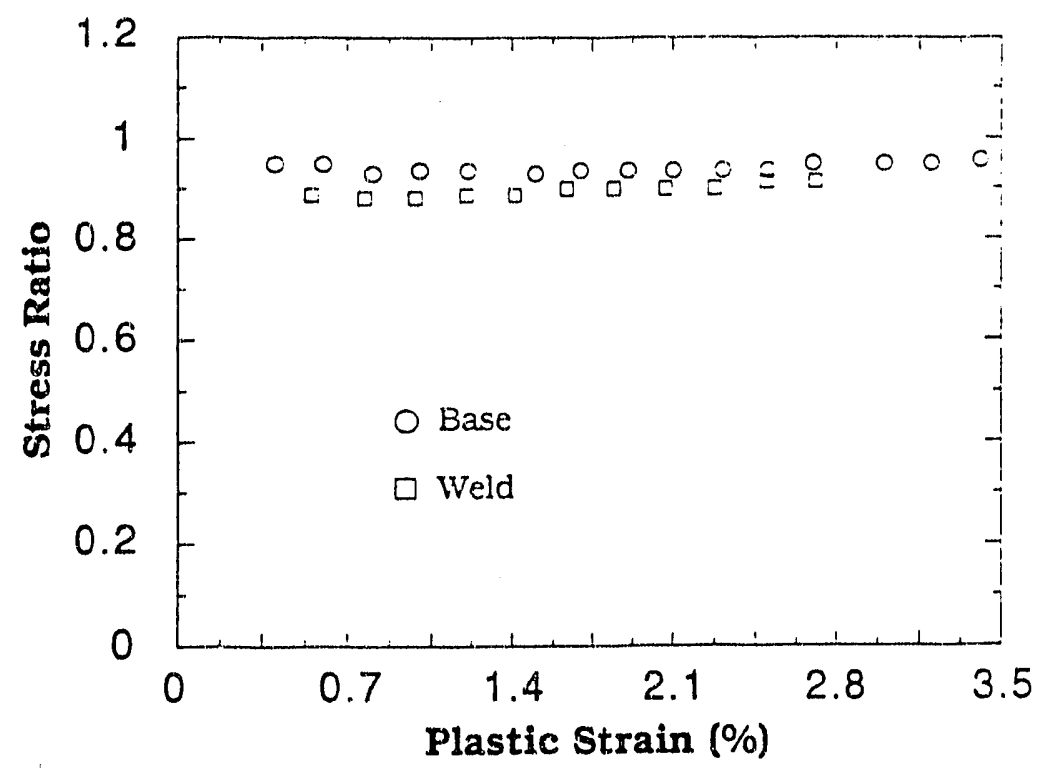

Fig. 21. Comparison of SCC Susceptibility of Cu-30Ni Base Metal and Weldment Spectmens in Simulated $\mathrm{J}-13$ Water at $93^{\circ} \mathrm{C}\left(\varepsilon=1 \times 10^{-7} \mathrm{~s}^{-1}\right)$ 


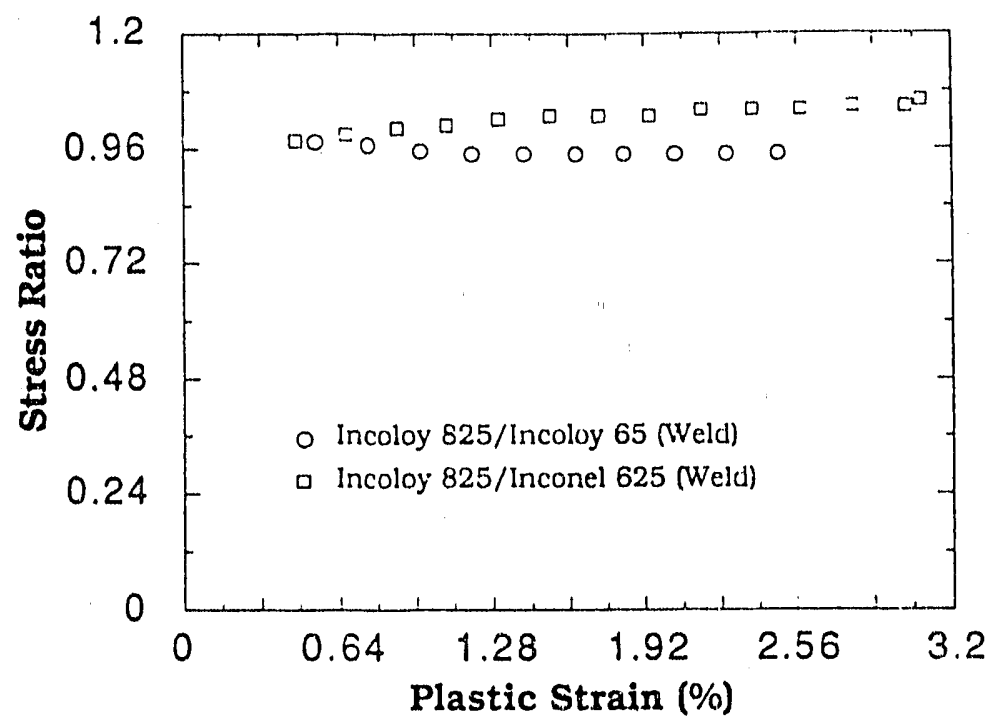

Fig. 22. Comparison of SCC Susceptibility of Incoloy 825 Incoloy Weldment Specimens with two Different Filler Materials in Simulated $J-13$ Water at $93^{\circ} \mathrm{C}\left(\dot{\varepsilon}=1 \times 10^{-7} \mathrm{~s}^{-1}\right)$

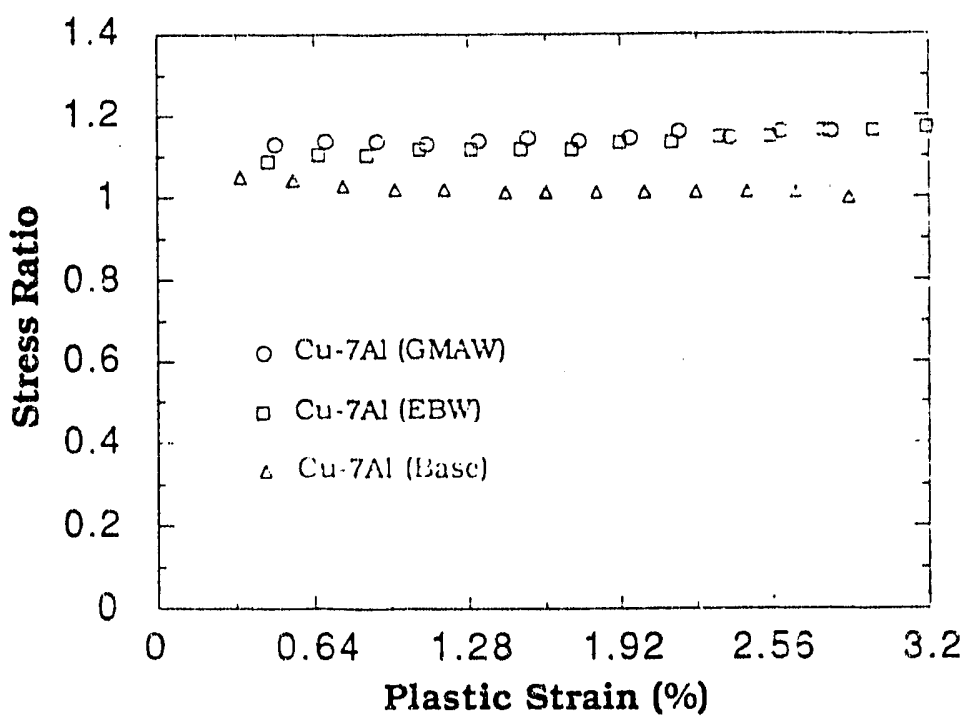

Fig. 23. Comparison of SCC Susceptibutity of Cu-7Al Base. Electron-Beam-Welded and Gas-Metal-Arc Welded Specimens in Simulated $J-13$ Water at $93^{\circ} \mathrm{C}\left(\dot{\varepsilon}=1 \times 10^{-7} \mathrm{~s}^{-1}\right)$ 


\subsubsection{Influence of Strain Rate on SCC}

Figures 24-29 shniv the effect of strain rate on the SR for Types 304L and 316L SS, Incoloy 825, $\mathrm{Cu}, \mathrm{Cu}-7 \mathrm{Al}$, and $\mathrm{Cu}-30 \mathrm{Ni}$ at different plastic strains. The strain rate appears to influence the SR of Types 304L SS and 316L SS, Incoloy 825, and Cu, but it has virtually no effect on the SR of $\mathrm{Cu}-30 \mathrm{NI}$ and $\mathrm{Cu}-7 \mathrm{Al}$. The effect is more pronounced for Type 304L SS than for Type 316L SS or the other materials. The lower values of the SR at a lower strain rate suggest an increase in susceptibllity to cracking typical of SCC. Similarly, these results suggest that the cracking observed for $\mathrm{Cu}-30 \mathrm{Ni}$ and $\mathrm{Cu}-7 \mathrm{Al}$ at the higher strain rate may not be SCC. However, as pointed out earlier, both the exposure conditions and water chemist $y$ are different for the tests performed at the two strain rates. It appears that the strain-l:,te effects on the SR are coupled with the environmental effects. More specificaily, the simulated $\mathrm{J}-13$ water used for the slower strain-rate experiments in tests on Types 304L and 316L SS and on Incoloy 825 are more oxidizing, which is reflected in the higher values of specimen ECP (Figs. 24-26). A more oxidizing environment also tends to lower the SR. As will be discussed later, even at the same strain rates, the change in the SR appears to be correlated with the change in the specimen electrochemical potential (ECP). These results suggest that the ECP, pH, and other environmental variables must be controlled to more clearly delineate the strain-rate effects on the SCC susceptibility of different materials.

\subsubsection{Measurement of Crack Depth in SSRT Specimens}

Attempts have been made to measure the crack depths by transverse sectioning of the SSRT specimens. In Type 304L SS (test W-4), multiple sections were examined by alternately grinding away $\approx 4-5$ mils of material and metallographically preparing the resulting new surface. Even after as much as 20 mils of material had been removed in this manner, only small cracks $(\approx 10 \mu \mathrm{m}$ in depth) were observed. Even these cracks may be artifacts of the procedure used to produce the small-diameter holes in the gauge reglon. However, such cracks have not been observed in unstressed specimens with holes exposed to simulated $\mathrm{J}-13$ water at $93^{\circ} \mathrm{C}$ for the same length of time. Consequently, it appears that we must modify our testing methods to produce cracks of greater depth. For example. it may be desirable to consider tests strained to fallure under identical environmental conditions so that the relative susceptibility of the materials can be quantified in terms of maximuin crack depth and crack depth distribution or crack growth rate. This approach may provide another means of resolving the relatively small differences in the cracking behavior of the most resistant materials, and may also confirm some of the preliminary findings of the interrupted tests. Further attempts to determine the crack depth in specimens subjected to larger strains than in test W-4 will be discussed later.

\subsubsection{Influence of Water Chemistry on SCC}

Tests W-1 and W-2 were performed on Incoloy 825 with different concentrations of lonic species in the water, but at the same strain rate of $1 \times 10^{-7} \mathrm{~s}^{-1}$. The cracking behavior in terms of SR (Fig. 30) appears to be very similar. The appearance of the cracks in the two specimens as observed by SEM is also very similar. Although the water chemistry is different for these two tests, the approximately identical stress ratio observed (see Table 11) is consistent with the ECP of the specimen (233-253 $\mathrm{mV}$ standard hydrogen electrode [SHE]) measured in the two environments (Fig. 30). 
Tests $\mathrm{W}-5$ and $\mathrm{W}-12$ on $\mathrm{Cu}$ are similar, except that in test W-12 a small amount of $\mathrm{H}_{2} \mathrm{O}_{2}$ was added to the feedwater. Although this addition did not significantly change the ECP of the material, the lower SR (Fig. 31) suggests that $\mathrm{H}_{2} \mathrm{O}_{2}$ may be detrimental. However, it was difficult to observe differences in cracking by SEM.

\subsection{SSRT Results (Tests W-23/W-33)}

Because of the controlled water chemistry and water flow through the the environmental chamber as a result of introducing a mechanical pump discussed earlier, several tests were repeated for the five candidate alloys, namely, Types 304L SS and 316L SS, Incoloy 825, Cu-30Ni, and $\mathrm{Cu}-7 \mathrm{Al}$. As shown in Table 16, all but two of the tests were performed at a strain rate of $1 \times 10^{-7} \mathrm{~s}^{-1}$. The tests for Type 304L and 316L SS involved large plastic elongations, and these specimens were metallographically examined to determine the deepest crack or crack distribution. Such observations would permit a better understanding of the relative SCC susceptibility of these materials.

In addition, in general, the tests (W-23/W-33) were generally interrupted at higher strains $\left(e_{p}=5-18 \%\right)$ than were tests $w-2 / W-7\left(e_{p}=3-4 \%\right)$ and these tests permit screening of the five alloys under better-defined environmental and slightly lower ECP conditions than the early tests. Furthermore. for Type 304L SS. Incoloy 825, and Cu$30 \mathrm{Ni}$, duplicate experimental results are obtained to check the reproducibility of stress/strain data used to obtain SR, because the rankings of different materials used in the program are solely based on stress or strain ratio. For $\mathrm{Cu}-30 \mathrm{Ni}$ and $\mathrm{Cu}-7 \mathrm{Al}$ alloys, experiments were performed at the slightly lower strain rate of $5 \times 10^{-8} \mathrm{~s}^{-1}$ to determine any observable effect of strain rate on the SR. This strain-rate was chosen so that these tests could be interrupted at higher plastic strains near those of tests run at faster strain rates within a reasonable length of time.

For previous tests (W-2/W-7). we have computed strains from the measured plastic strain at the time of interruption and interpolated back by means of strain rate and time (strain-rate method, Eq. 16). For tests W-23 and W-33, we have computed strains by using both the strain-rate method and the displacement data from the dial indicator on the Jactuator. The extension data were recorded manually during the course of experiments, and these data, which are considered more accurate than those estimated from the strain-rate method, provide a comparison of SR values obtained by the two different methods. Additionally, for the last two tests (w-32 and w-33), an LVDT extensometer was attached to the specimen, and the elongation strains estimated from the displacement data provide another independent strain measurement. The data indicate that evaluation of materials using stress and strain ratios is not affected by the manner in which the strains are computed in the SSRTs.

\subsubsection{Crack Depth Distribution in SSRT Specimens}

The SEM observations showed cracking in all specimens, and it was difficult to quantify these observations to determine whether cracking is more severe in specimens subjected to larger plastic strains and which material is most resistant to cracking. 


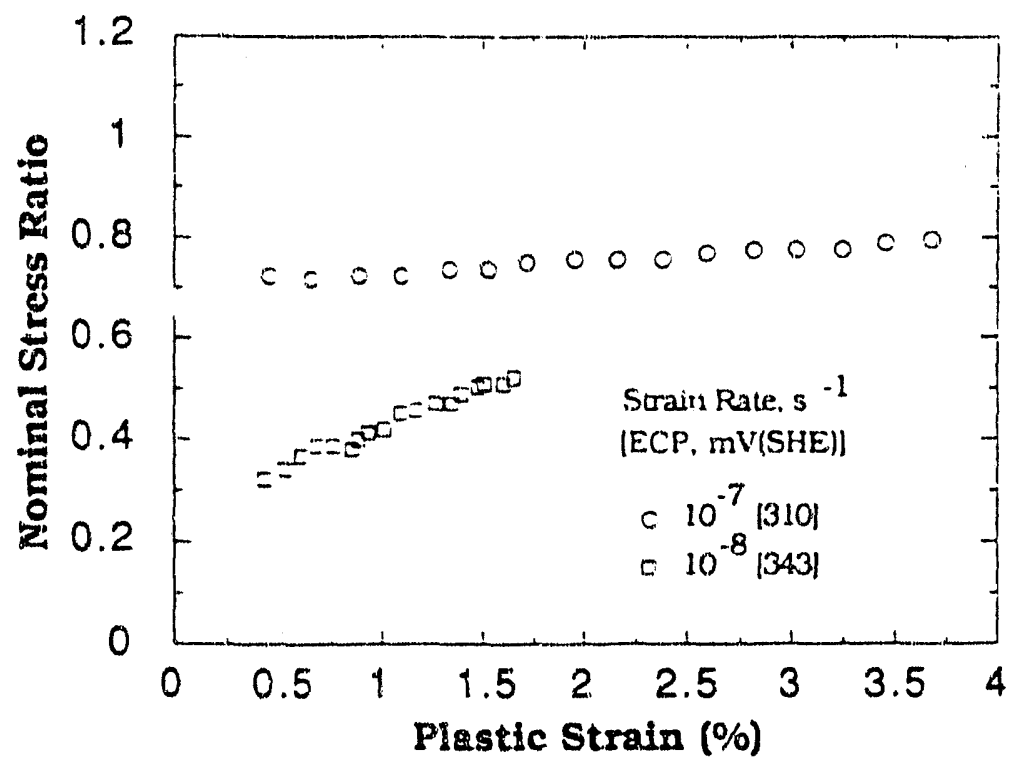

Fig. 24. Effect of Strain Rate and Spectmen E.CP on SCC Susceptlbulty of Type 304L. SS in Stmulated $\mathrm{J}-13$ Water at $93^{\circ} \mathrm{C}$

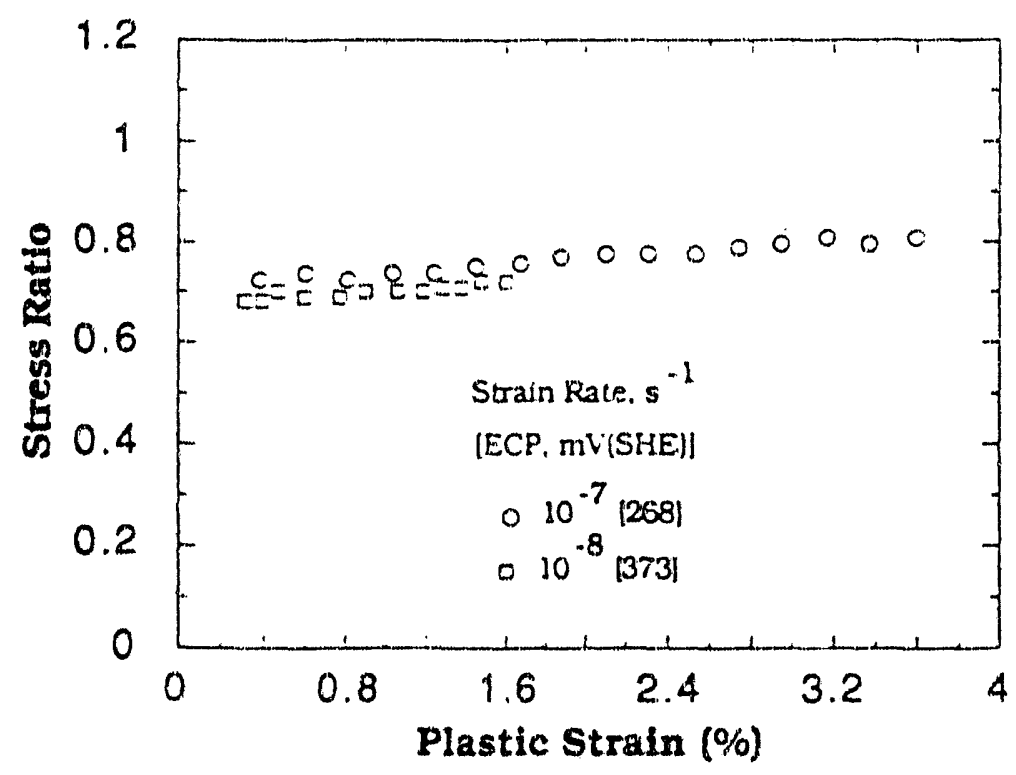

Fyg. 25. Effect of Strain Rate and Spectmen ECP on SCC Susceptibdity of Thpe 316L SS in Stmulated J13 Water at $93^{\circ} \mathrm{C}$ 


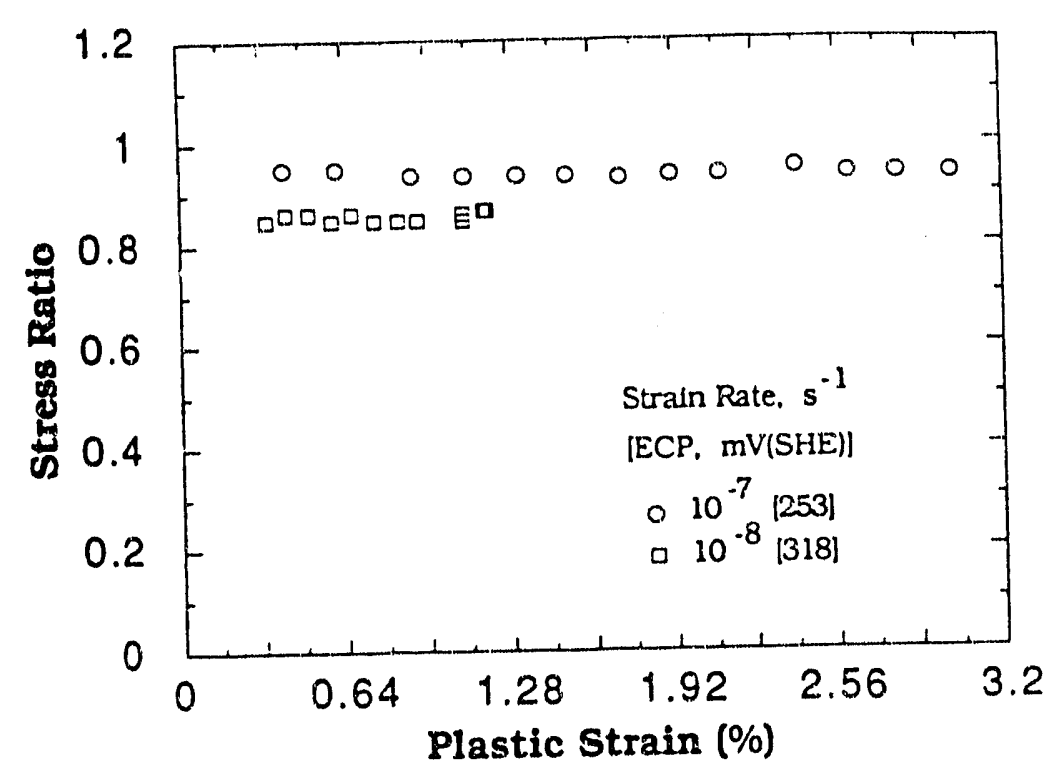

Fig. 26. Effect of Strain Rate and Specimen ECP on SCC Susceptiblity of Incoloy 825 in Simulated $J-13$ Water at $93^{\circ} \mathrm{C}$

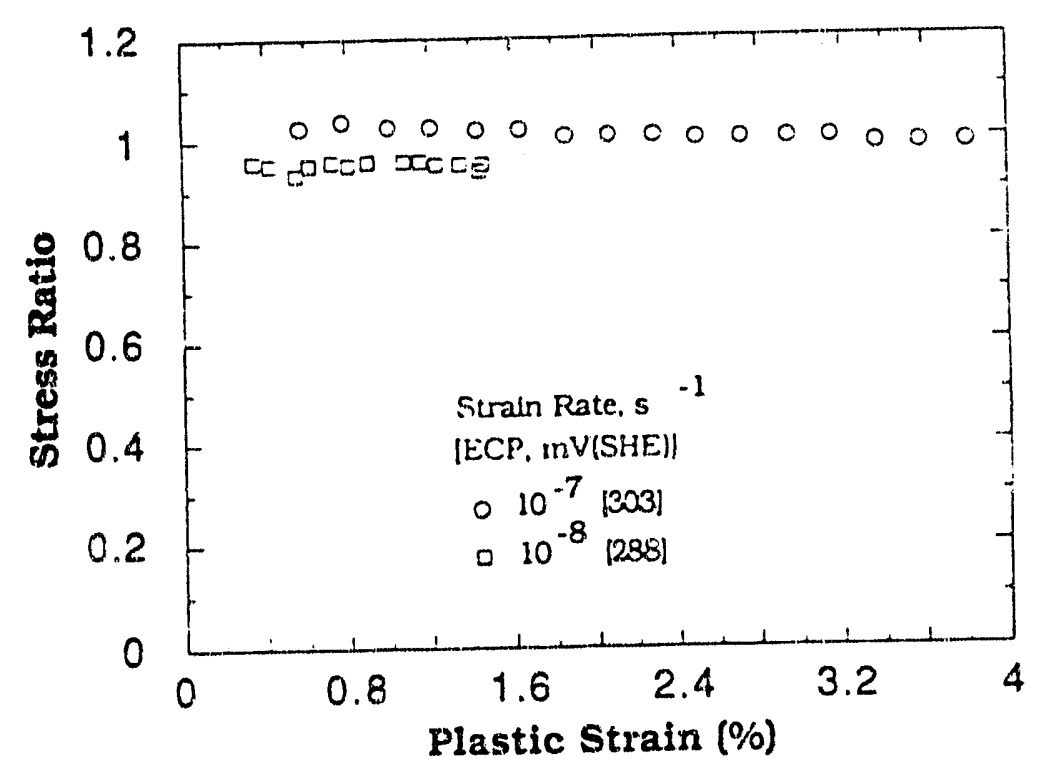

Iv. 27. Effect of Strnin Rate and Spectmen ECP on SCC Susceptibitity of $\mathrm{Cu}$ in Simulated $j-13$ Water at $9.3^{\circ} \mathrm{C}$. 


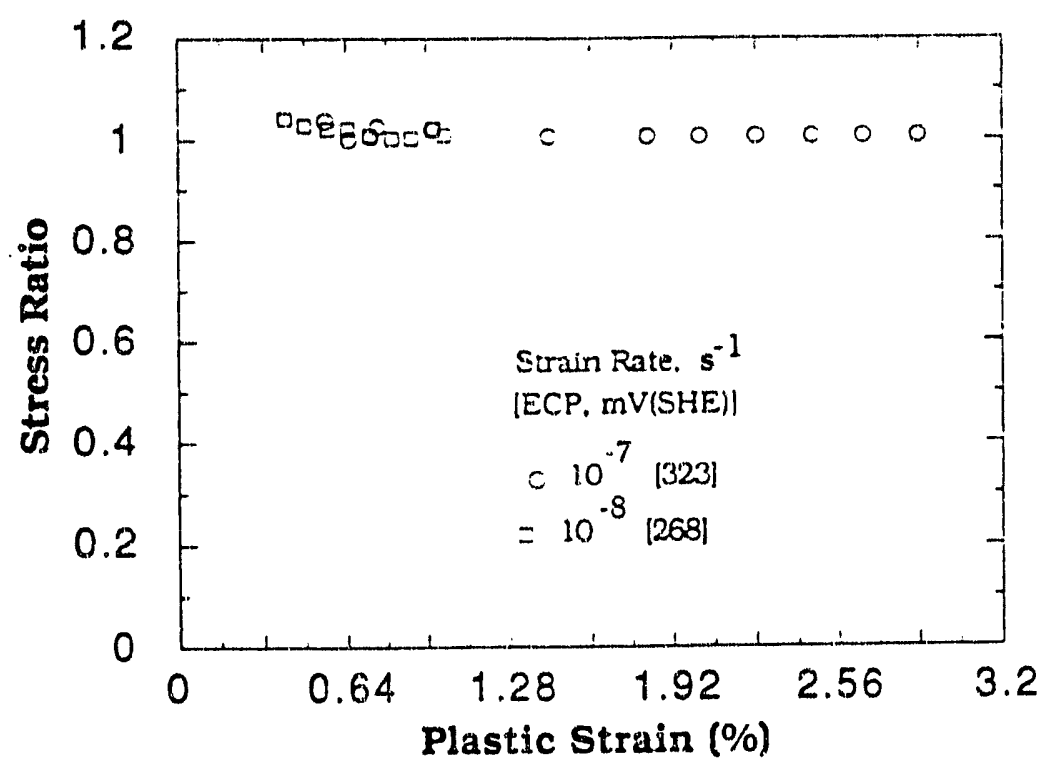

Fig. 28. Effect of Strain Rate and Specimen ECP on SCC Susceptibility of Cu-7Al in Sunulated J-13 Water at $93^{\circ} \mathrm{C}$

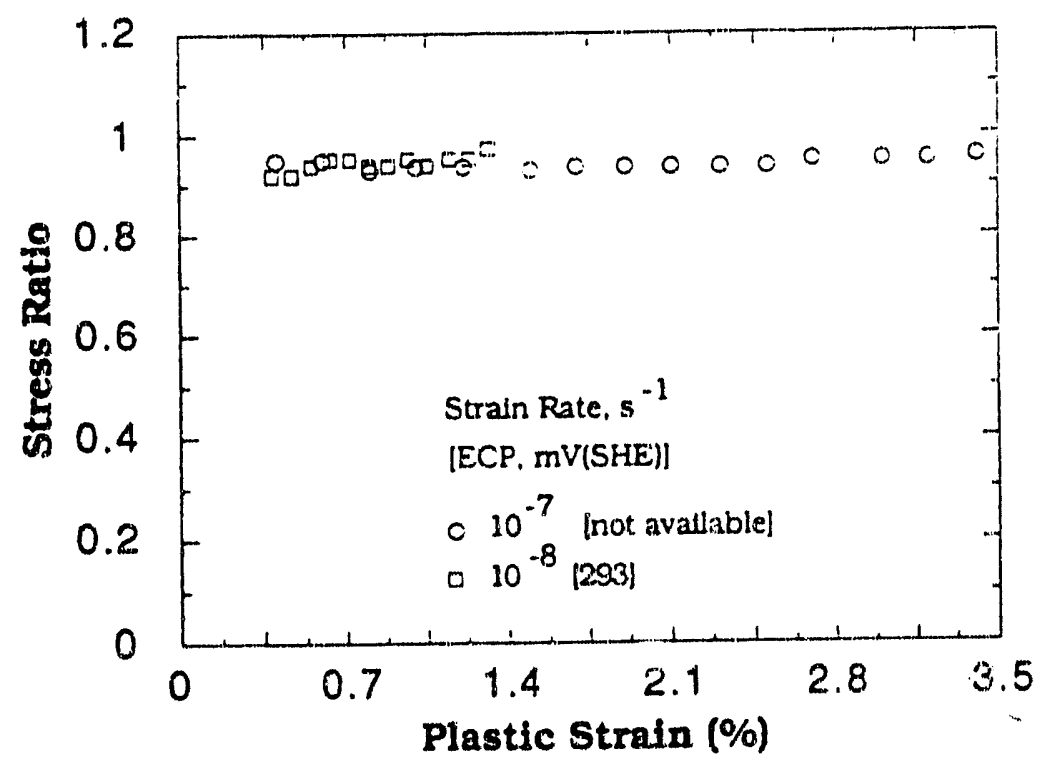

FG. 29. Effect of Strain Rate and Spectmen ECP on SCC Suscentihlitiy of Cu-30Ni in Simulated $\mathrm{J}-13$ Water at $93^{\circ} \mathrm{C}$ 


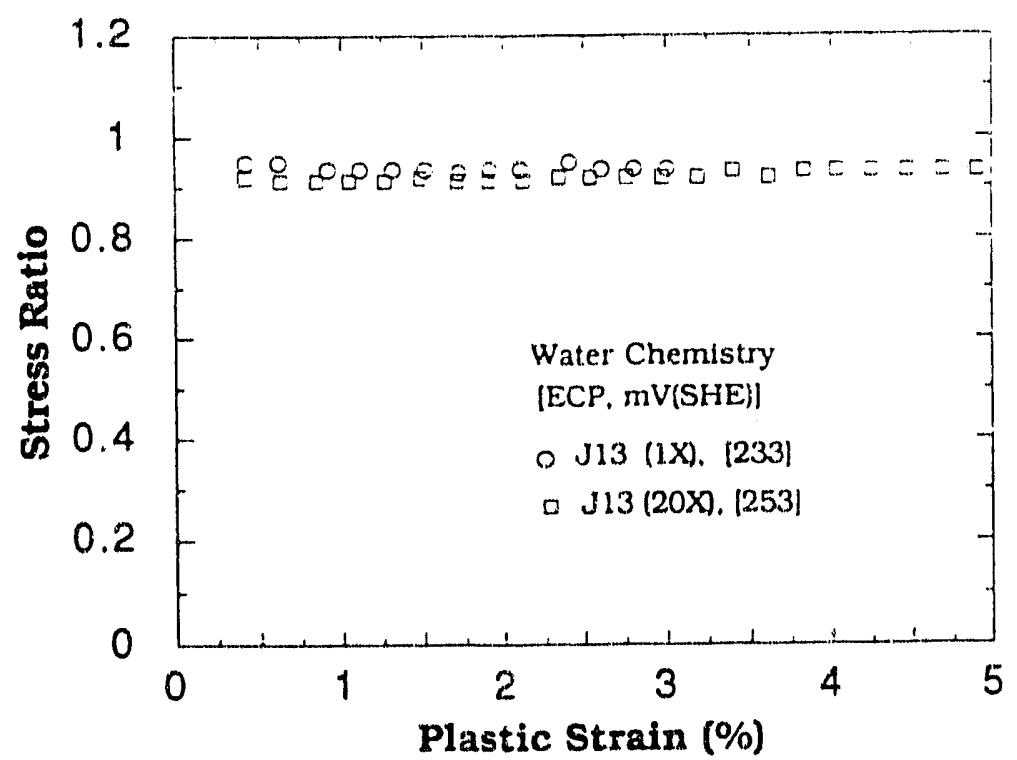

Fig. 30. SCC Susceptibilty of Incoloy 825, as Indicated by the Stress Ratio for Tests with Different Water Chemistries under Approximately the Same ECP Conditions at $93^{\circ} \mathrm{C}\left(\dot{\varepsilon}=1 \times 10^{-7} \mathrm{~s}^{-1}\right)$

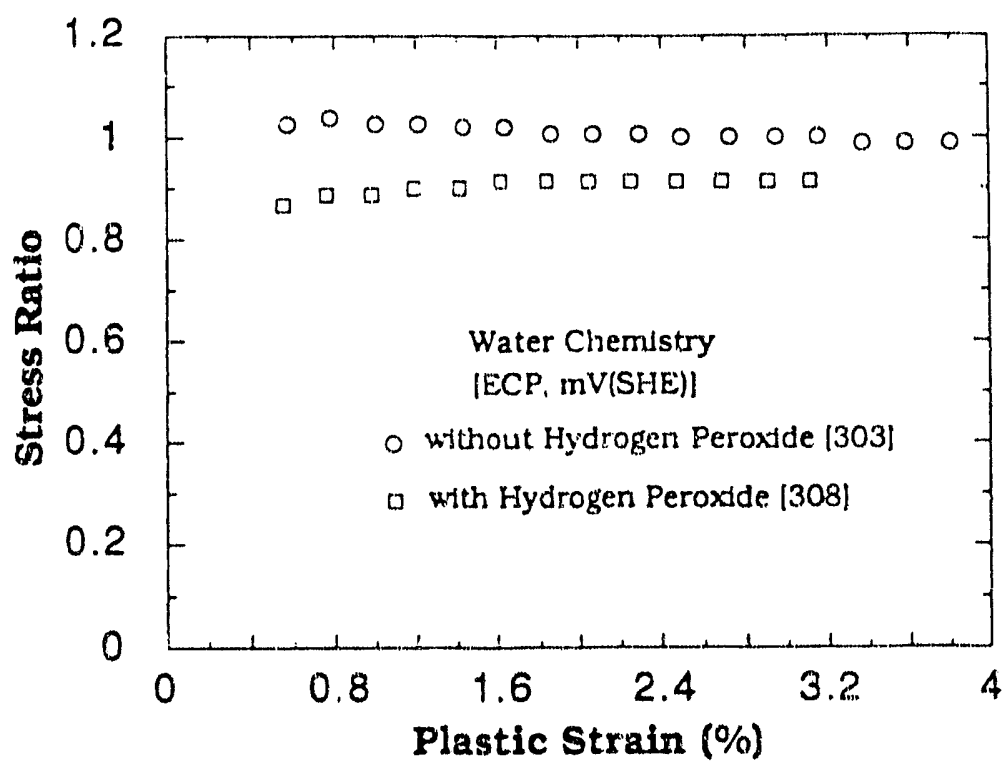

Fig. 31. SCC Susceptibulty of Cu in Terms of the Stress Ratio for Tests Conducted in Simulated Water without and inth $-1.0 \mathrm{npm} \mathrm{H}_{2} \mathrm{O}_{2}$ at $9.3^{\circ} \mathrm{C}\left(\varepsilon=1 \times 10^{-7} \mathrm{~s}^{-1}\right)$ 
Some preliminary results on Types 304L and 316L SS specimens suggest that it is possible to determine crack depth distribution, even though the crack depths are smaller than $=100 \mu \mathrm{m}$. The crack depth distribution in a given specimen may be determined from transverse sections produced by alternately grinding of layers of $\approx 0.1-0.15 \mathrm{~mm}$ in thickness, metallographically preparing and examining the resulting new section, and determining the deepest crack observed. The distribution of crack depths observed on a single transverse section in a Type $316 \mathrm{~L}$ SS specimen (test W-24) is shown in Fig. 32 . The distribution of maximum depths observed in four to flve transverse sections is shown for both Types 316L and 304L SS specimens in Fig. 33. These results show that even in the materials most susceptible to cracking in simulated $\mathrm{J}-13$ water, the maximum cracking observed is still small even after large plastic elongations. Therefore, the depth distribution results for the materials may not be very useful in relating to the $S R$, at least for the materials and environment under consideration.

Table 16. SSRTs on Waste Container Materials at a Strain Rate $10^{-7} \mathrm{~s}^{-1}$ in Simulated $J-13$ Water at $93^{\circ} \mathrm{C}$

\begin{tabular}{lccccc}
\hline $\begin{array}{l}\text { Test } \\
\text { Number }\end{array}$ & Material & $\begin{array}{c}\text { Heat } \\
\text { Number }\end{array}$ & $\begin{array}{c}\text { Specimen } \\
\text { ECP } \\
(\mathrm{mV}[\mathrm{SHE})\end{array}$ & $\begin{array}{c}\text { Elongation, } \\
(\%)\end{array}$ & $\begin{array}{c}\mathrm{K}_{\mathrm{t}}^{\mathrm{a}} \\
\left(10^{6} \mathrm{~kg} \cdot \mathrm{m}^{-1}\right)\end{array}$ \\
\hline W-23 & 304L & V70200 & 388 & $26.6^{\mathrm{b}}$ & 1.64 \\
W-24 & $316 \mathrm{~L}$ & 16650 & 373 & 18.2 & 1.69 \\
W-26 & 304L & V70200 & 368 & 5.6 & 1.64 \\
W-27c & Cu-30Ni & 673 & 268 & 6.1 & 1.68 \\
W-28c & Cu-7Al & M5485 & 258 & 5.0 & 1.43 \\
W-29 & Cu-7Al & M5485 & 253 & 5.5 & 1.41 \\
W-30 & Incoloy 825 & H2125F & 328 & 5.7 & 1.75 \\
W-31 & Cu-30N1 & 673 & 258 & 5.6 & 1.61 \\
W-32d & Incoloy 825 & H2125F & 368 & 11.93 & 1.68 \\
W-33d & Cu-30Ni & 673 & 258 & 11.88 & 1.60 \\
\hline
\end{tabular}

a $\mathrm{K}_{\mathrm{t}}=$ machine and specimen stiffness; see Eq. 18.

b Test was run to fallure: this is the fallure strain estimated from the strain rate and time to failure.

c Tests were run at a strain rate of $5.0 \times 10^{-8} \mathrm{~s}^{-1}$.

d For these tests, an LVDT extensometer was attached to the specimen to permit direct measurements of displacement in the specimen. 


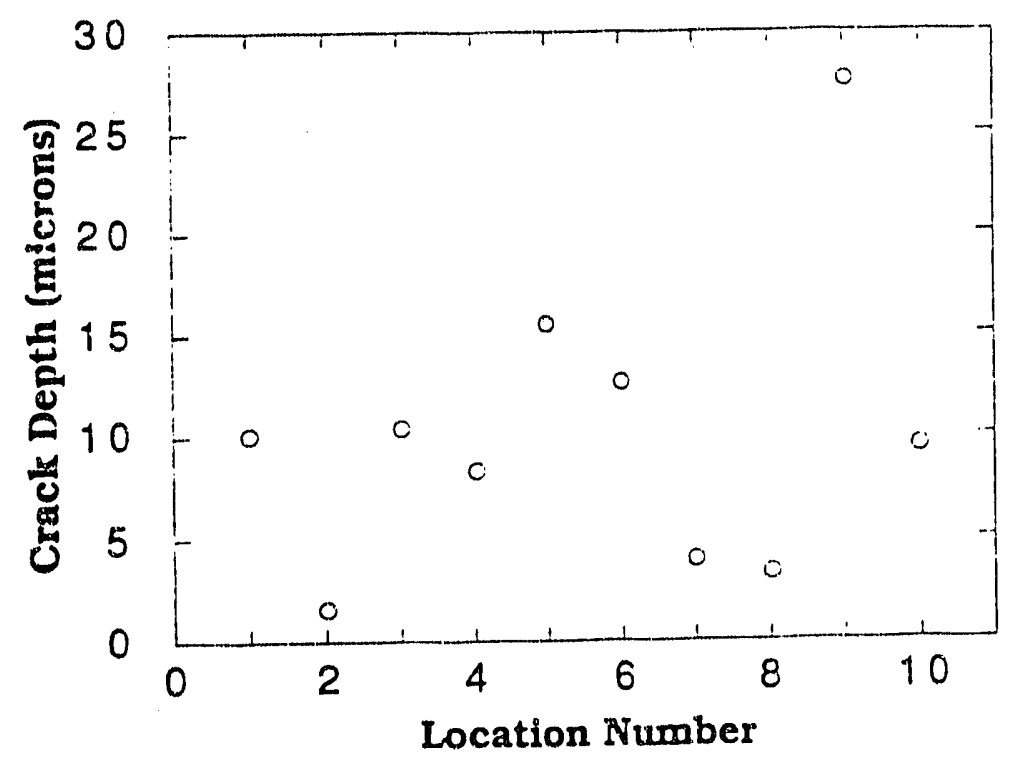

Fig. 32. Crack Depth Distribution on a Metallographically Polished Surface of a Transversely Sectioned Type 316L SS Specimen (Test W-24)

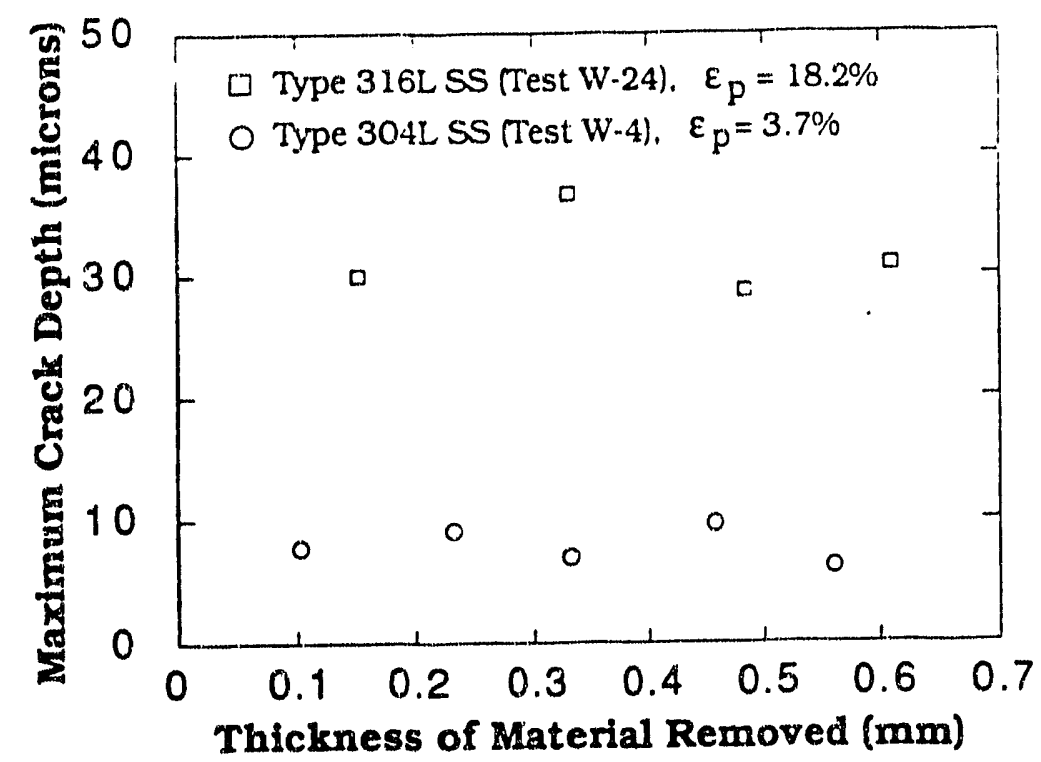

Fig. 33. Maximum Crack Depth as a Function of Material Removed for SSRT Specimens 


\subsubsection{Relative SCC Susceptibility of Waste Container Materials}

For tests $\mathrm{W}-23 / \mathrm{W}-33$, we have examined the effect of different strain computation methods on calculated SR and reproducibility of the SR In duplicate tests performed on three materlals, namely. Type 304L SS, Incoloy 825 , and Cu-30Ni. Once the most accurate method of computing the SR and its reproduclbility is established under controlled environments, it may then be possible to screen two materials for resistance to SCC even though the difference in the SCC susceptibility is qualitatively small.

For tests $\mathrm{W}-23 / \mathrm{W}-33$. the stress or straln ratio can be computed by using three measurements: strains estimated from the strain-rate method, pull-rod displacements from the dial indicator located on the Jactuator in the SSRT system, and displacements in the SSRT specimen determined with the LVDT extensometer. For displacements measured with the dial indicator, assuming that all of the plastic displacement $\left(\delta_{p}\right)$ occurs in the SSRT specimen, $\delta_{\mathrm{p}}$ is given by

$$
\delta_{p}\left(\delta-\frac{P}{K_{t}}\right)
$$

where $\delta t$ is the total displacement of the specimen and the loading system. $\mathrm{P}$ is the load. and $\mathrm{K}_{\mathrm{t}}$ is the stiffness of the specimen and the machine. The $\mathrm{d}_{\mathrm{t}}$ must be corrected for any backlash in the system. For the two SSRT systems, this backlash has been estimated ${ }^{9}$ as 0.0025 and $0.0038 \mathrm{~cm}$, depending on the machine used. $K_{t}$ can be calculated from $\delta t$ and $\delta_{\mathrm{p}}$ with the values at the time of test interruption. Here, $\delta \mathrm{t}$ is obtained from the dial indicator and $\delta_{p}\left(\varepsilon_{p}=\delta_{p} / L\right.$, where $L$ is the gauge length of the SSRT specimen) is the plastic elongation determined by measuring the specimen length before and after the test. With the value of $K_{t}$ thus determined. plastic strain can then be determined as a function of nominal stress from the load-extension data for the tests under consideration. The stress or strain ratio is then estimated from the stress/strain data in a manner similar to that discussed before.

For tests $w-32$ and $w-33$, the LVDT extensometer attached to the specimen was used to obtain the displacement in the specimen as a function of $P$. For this case, $\delta p$ is gtven by

$$
\delta_{\mathrm{p}}\left(\delta_{\mathrm{t}}-\frac{\mathrm{P}}{\mathrm{K}_{\mathrm{s}}}\right)
$$

where $\mathrm{K}_{\mathrm{S}}$ is the specimen stiffness equal to 0.93EA/L, $\mathrm{E}$ is the Young's modulus, and $\mathrm{A}$ is the cross-sectional area. The factor of 0.93 is introduced to account for the specimen shoulder deformation. 10 The specimen stiffness values thus determined for Incoloy 825 (test $\mathrm{W}-32$ ) and $\mathrm{Cu}-30 \mathrm{Ni}$ (test $\mathrm{W}-33$ ) are $1.56 \times 10^{7}$ and $1.23 \times 10^{7} \mathrm{~kg} \cdot \mathrm{m}^{-1}$, respectively. The plastic strain is computed by dividing the plastic displacement by $\mathrm{L}$. From the plastic strain determined as a function of nominal stress, the SR or the strain ratio is computed as before.

Figures 34 and 35 show the plots of stress and plastic strain for the three methods of strain computation for Incoloy 825 and $\mathrm{Cu}-30 \mathrm{NI}$, and the corresponding plots of stress 
ratio versus plastic strain are shown in Figs. 36 and 37, respectively. As can be seen, the method of strain computation has virtually no effect for Incoloy 825 and only a small effect for $\mathrm{Cu}-30 \mathrm{Ni}$ at strains $<6-7 \%$. For both materials, the strain computation method using the dial indicator and extensometer gives very good agreement. We will later examine the ranking of different alloys in terms of increasing resistance to SCC on the basis of these data.

With regard to the reproducibility of the stress/strain response and SR from duplicate tests on Type 304L SS, Incoloy 825, and Cu-30Ni (regardless of the strains at which the test was interrupted). the results are in close agreement. Figures 38 and 39 demonstrate that both the stress/strain plots and the corresponding plots of stress ratio versus plastic strain for Type $304 \mathrm{~L}$ are reproducible with no discernible scatter. Similar agreement has been obtained from duplicate tests performed on Incoloy 825 and $\mathrm{Cu}-30 \mathrm{Nl}$, as shown in Figs. 40-43.

The SSRT results from tests $\mathrm{W}-2 / \mathrm{W}-7$ performed on different materials at a strain rate of $10^{-7} \mathrm{~s}^{-1}$ are compared with results obtained from tests $\mathrm{W}-23 / \mathrm{W}-33$, which were conducted at the same strain rate but under slightly higher ECP conditions. Figures 44-48 display such comparison plots of stress ratio versus $\varepsilon_{p}$ for Types $304 \mathrm{~L}, 316 \mathrm{~L}$ SS. Incoloy 825. $\mathrm{Cu}-30 \mathrm{NI}$, and $\mathrm{Cu}-7 \mathrm{Al}$, respectively. Because the extension measurements by dial indicator are not available for tests $\mathrm{W}-2 / \mathrm{W}-7$, we used the strain-rate method to compute the results. Figures 44-48 show that the disagreement between the two tests is significant for Type 304L SS (W-4 and W-26, Fig. 44), Type 316L SS (W-6 and W-24, Fig. 45), Incoloy 825 (W-2 and W-32, Fig. 46), and Cu-30Ni (W-3 and W-33, Fig. 47). However, there is close agreement between the results of two tests (W-7 and W-29, Fig. 48) for Cu-7Al, which also happens to be the most crack-resistant material. Similar comparison data for $\mathrm{Cu}$ are not avallable.

The disagreement in results for the four alloys cannot be reconclled in terms of the method of computing strains (because all the methods discussed in this report essentially lead to approximately identical results), but instead appears to be associated with the change in environmental and exposure conditions. In fact, the disagreement in results is better correlated with specimen ECP, at least for Type 304L (Fig. 44). Type 316L SS (Fig. 45), and Incoloy 825 (Fig, 46). In particular, the higher specimen ECP tends to give a lower SR, 1.e., higher specimen ECP consistently results in gi vater susceptibility. For tests conducted under approximately the same ECP conditions, almost identical results for the SR are obtained, as shown in Figs. 30, 39, 41, and 43. It is important to note that despite the vast difference in water chemistry for tests W-1 and W-2 (Fig. 30), approximately identical values for the SR are obtained. This is consistent with the fact that the same ECP values were measured in these two tests. Although it is easy to comprehend why a slightly more oxddizing environment produces a greater susceptibility to crucking with a resultant decrease in the SR, it is more difficult to obtain a fundamental understanding of how a shift in ECP value in the range of 250-380 $\mathrm{mV}$ (SHE) can affect the cracking susceptibility of austenitic stainless steels in simulated $J-13$ water at $93^{\circ} \mathrm{C}$. Such a shift in ECP has not been found to significantly affect the SCC susceptibility of Types 304 and 316L SS under bolling-water-reactor operating conditions. 


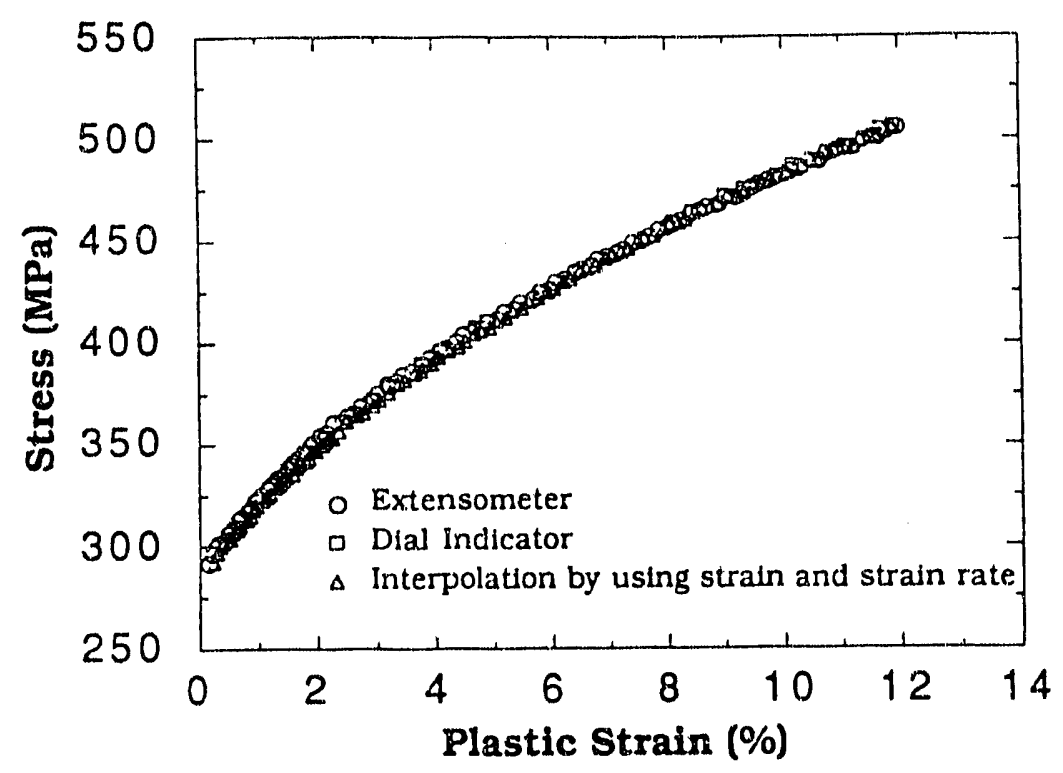

Fig. 34. Nominal Stress Versus Plastic Strain for Incoloy 825 (Test $W-32$ ) Specimen in Simulated $J-13$ Water at $93^{\circ} \mathrm{C}\left(\dot{\varepsilon}=1 \times 10^{-7} \mathrm{~s}^{-1}\right)$

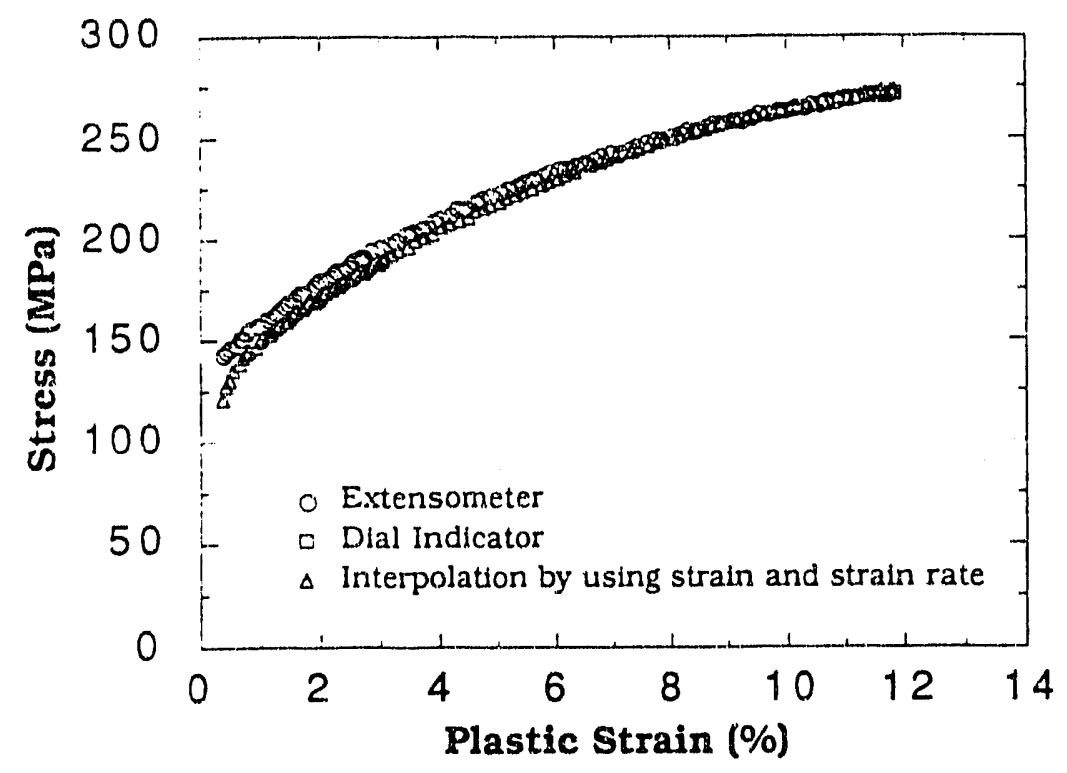

Fig. 35. Nominal Stress versus Plastic Strain for $\mathrm{Cu}-30 \mathrm{Ni}$ (Test $\mathrm{W}-33$ ) in Simulated $\mathrm{J}-13$ Water at $93^{\circ} \mathrm{C}$ $\left(\dot{\varepsilon}=1 \times 10^{-7}\right)$ 


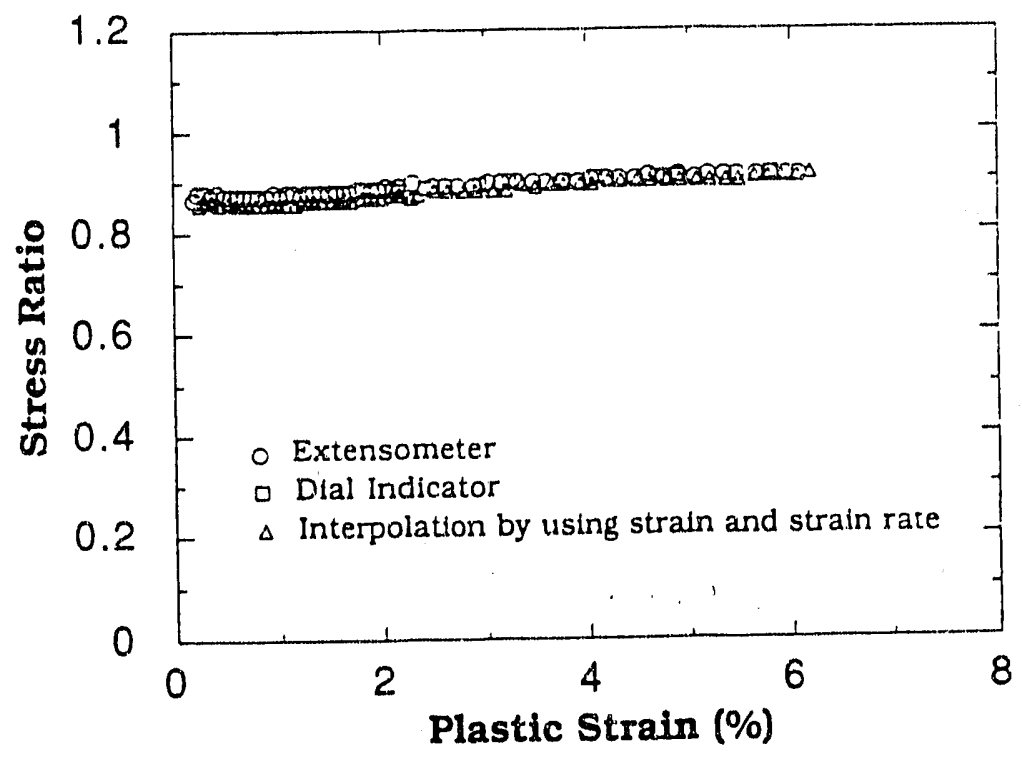

Fig. 36. Variation of Stress Ratio with Plastic Strain for Incoloy 825 (Test $W-32$ ) in Simulated $J-13$ Water at $93^{\circ} \mathrm{C}\left(\dot{\varepsilon}=1 \times 10^{-7} \mathrm{~s}^{-1}\right)$

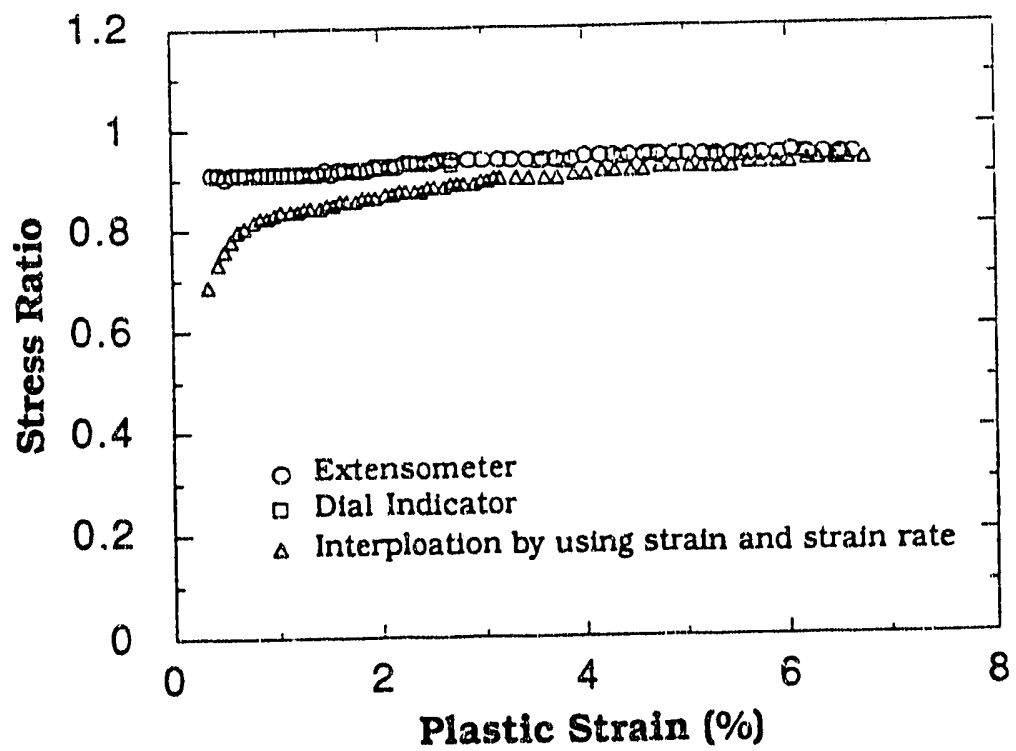

Fig. 37. Variation of Stress Ratio with Plastic Strain for Cu-30Ni (Test $W$-33) in Simulated $J-13$ Water at $93^{\circ} \mathrm{C}\left(\varepsilon=1 \times 10^{-7} \mathrm{~s}^{-1}\right)$ 


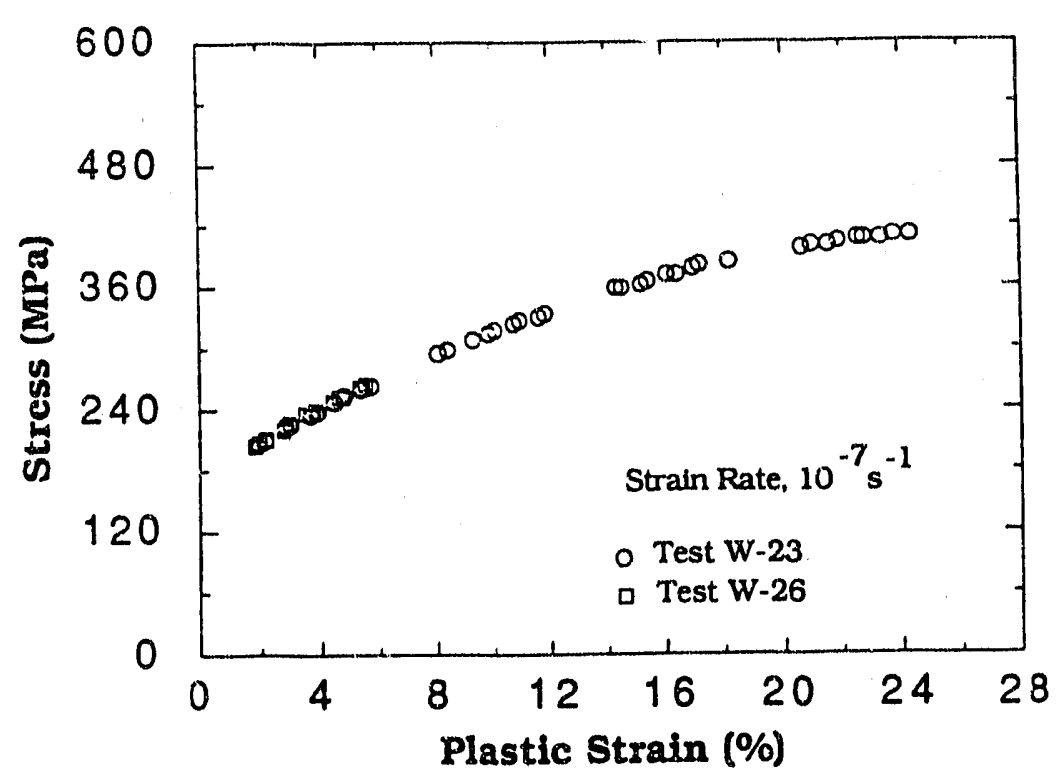

Fig. 38. Nominal Stress versus Plastic Strain for Type $304 \mathrm{~L}$ SS in Simulated $\mathrm{J}-13$ Water at $93^{\circ} \mathrm{C}$. $A$ dial indicator was used to estimate strains in the SSRT specimen.

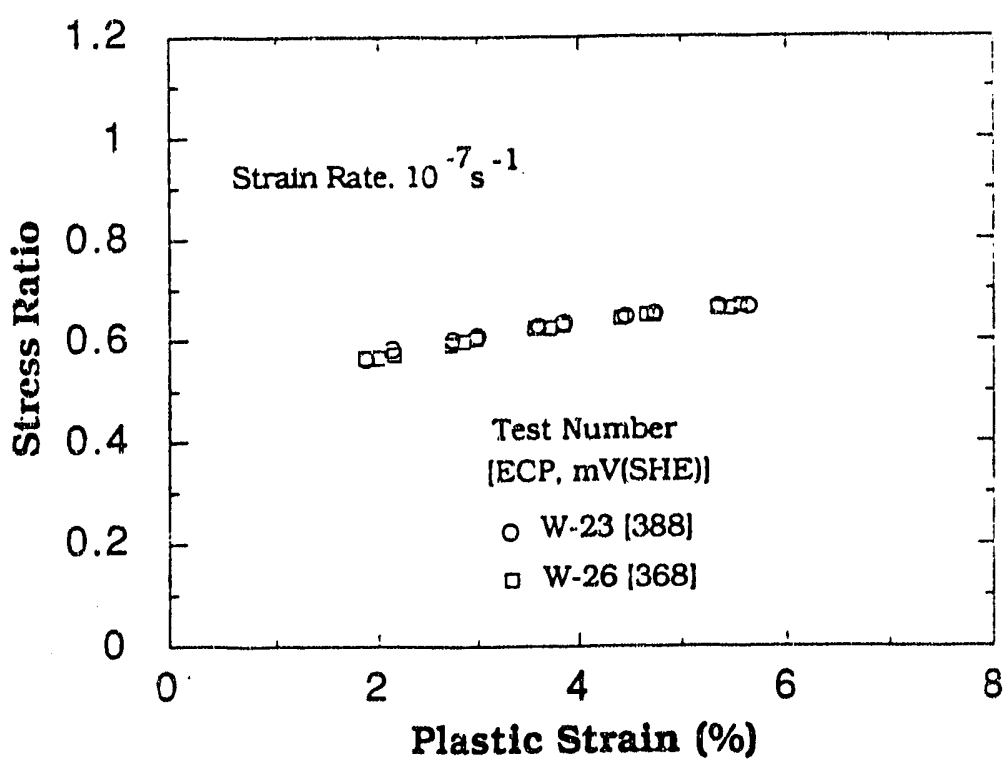

Fig. 39. Vartatton of Stress Ratio versus Plastic Strain for Type 304L SS in Stmulated $J-13$ Water at $93^{\circ} \mathrm{C}$. A dial indicator was used to esttmate strains in the SSRT specimen. 


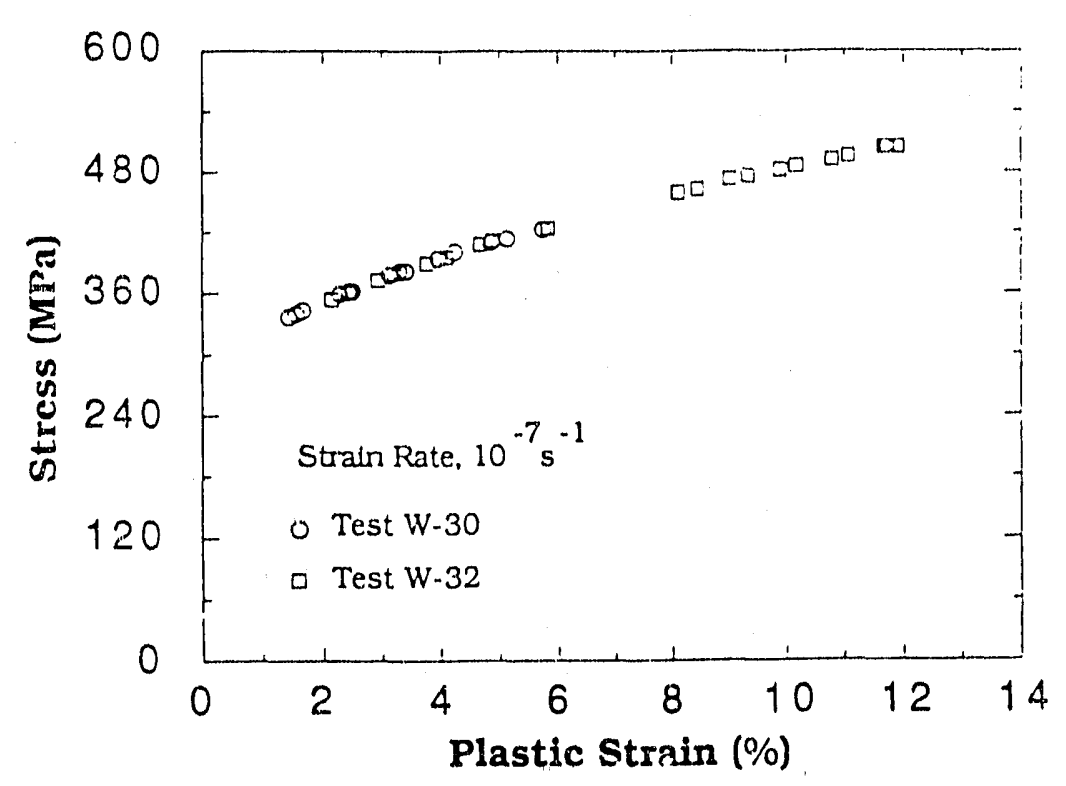

Fig. 40. Nominal Stress versus Plastic Strain for Incoloy 825 in Simulated $J-13$ Water at $93^{\circ} \mathrm{C}$. A dial indicator was used to estimate strains in the SSRT specimen.

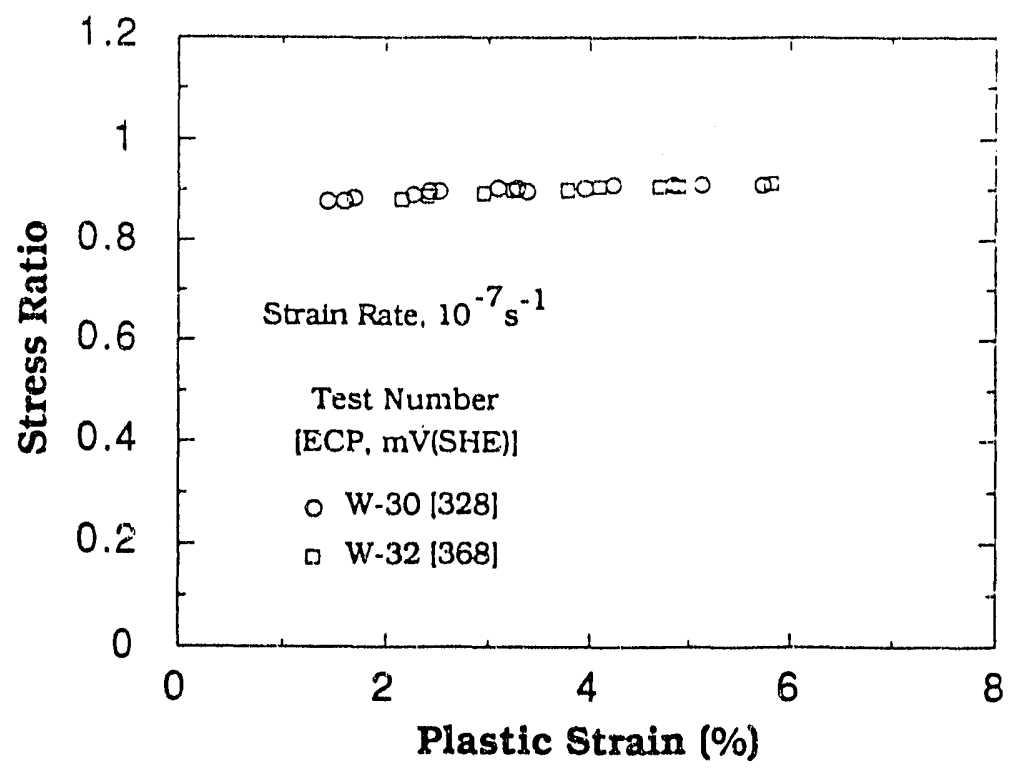

Fig. 41. Vartation of Stress Ratio versus Plastic Strain for Incoloy 825 in Simulated $\mathrm{J}-13$ Water at $93^{\circ} \mathrm{C}$. A dial indicator was used to estimate strains in the SSRT specimen. 


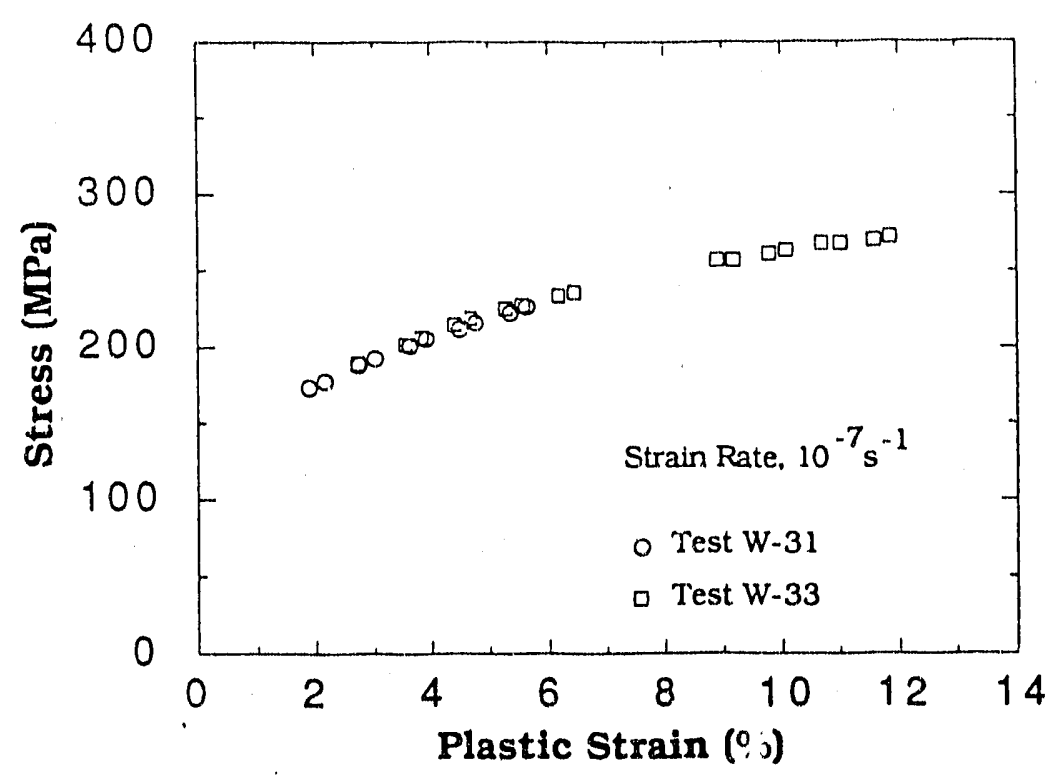

Fig. 42. Nominal Stress versus Plastic Strain for $\mathrm{Cu}-7 \mathrm{Al}$ in Simulated $\mathrm{J}-13$ Water at $93^{\circ} \mathrm{C}$. A dial indicator was used to estimate strains in the SSRT specimen.

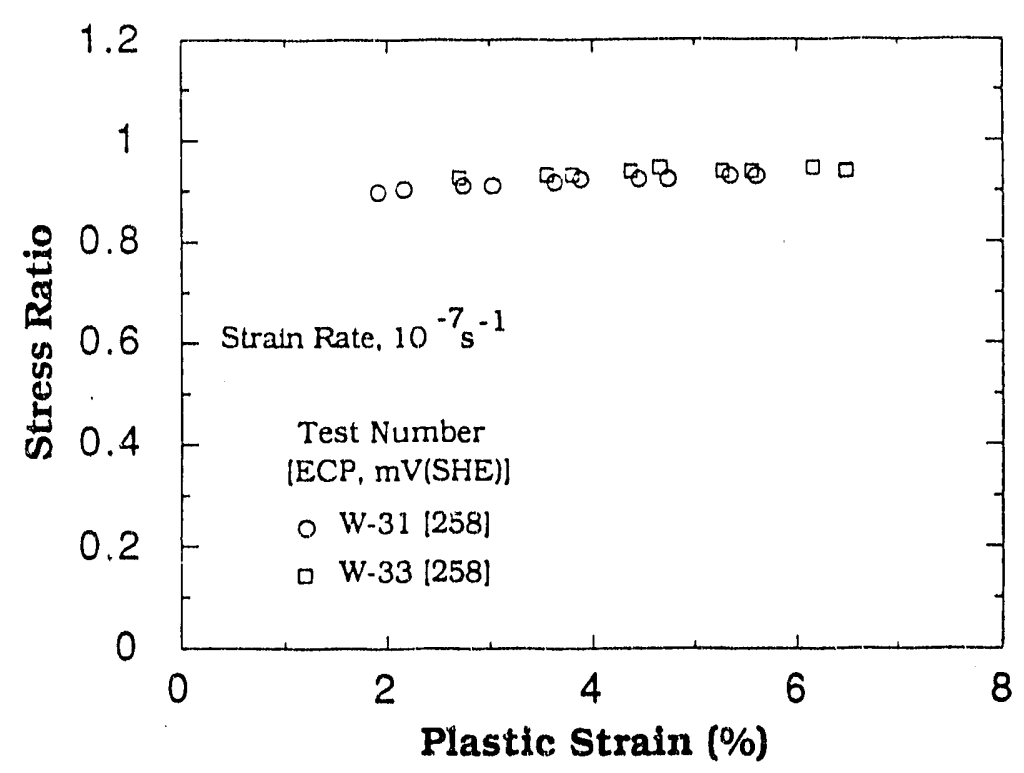

Fyg. 43. Variation of Stress Ratio versus Plastic Strain for Cu-30Ni in Simulated J-13 Water at $93^{\circ} \mathrm{C}$. A dial indicator was used to estimate strains in the SSRT specimen. 


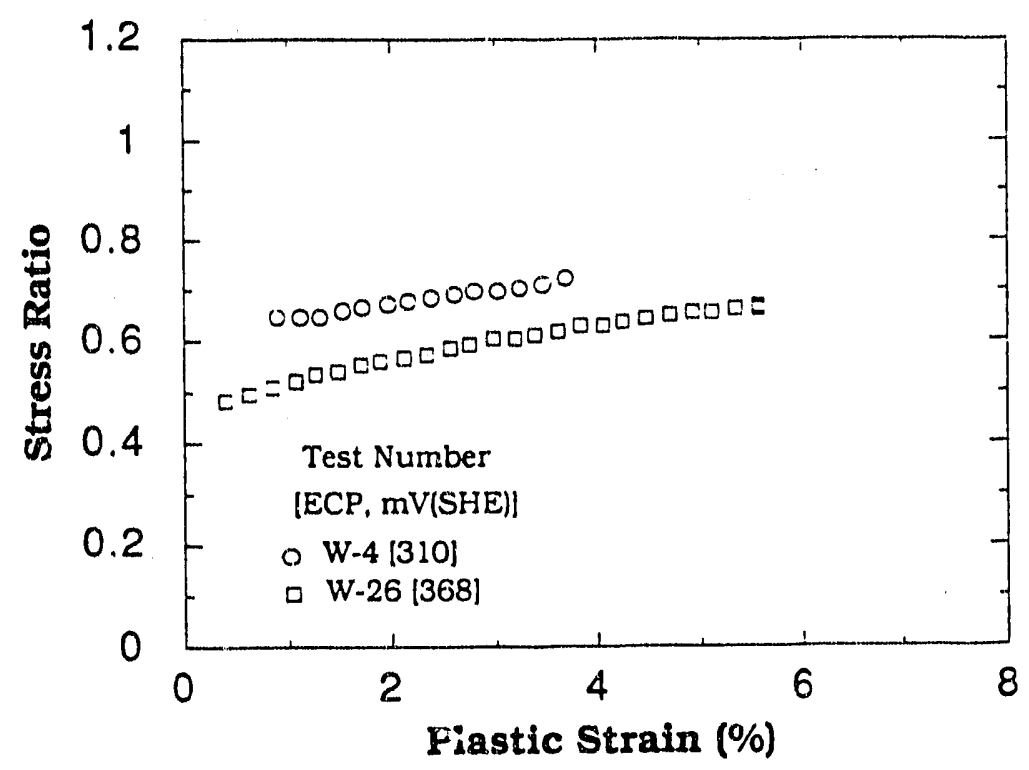

Fyg. 44. Comparison of Stress Versus Plastic Strain for Two Tests on Type 304L SS in Simulated $J-13$ Water at $93^{\circ} \mathrm{C}\left(\dot{\varepsilon}=1 \times 10^{-7} \mathrm{~s}^{-1}\right)$

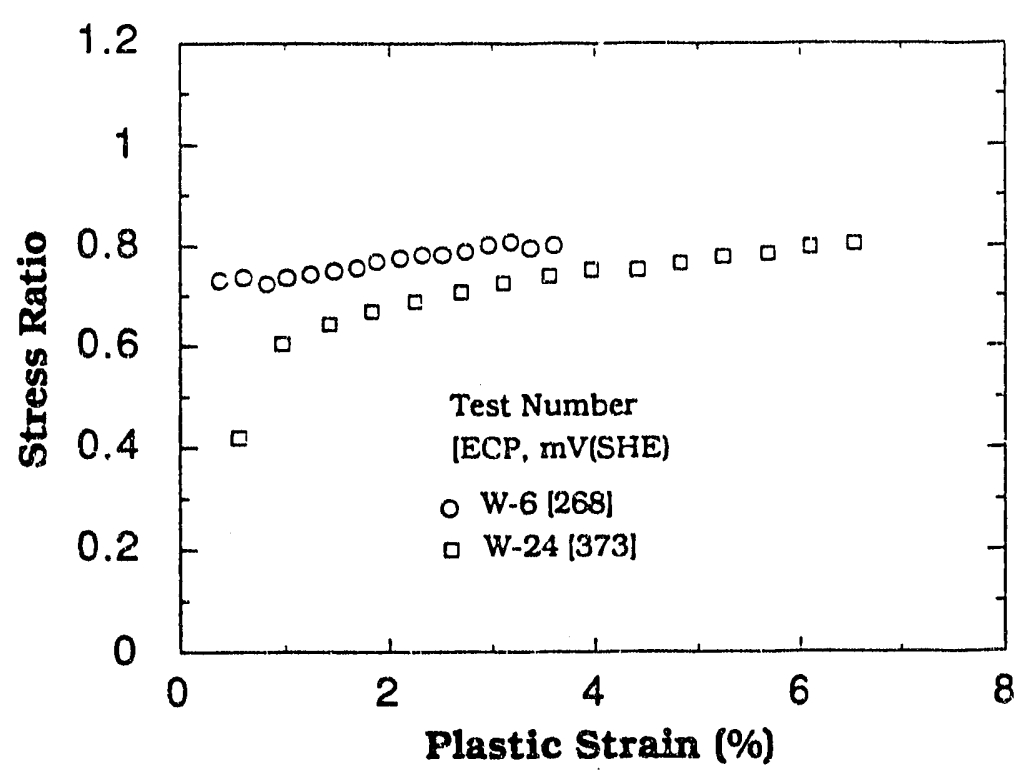

Fig. 45. Tomparison of Stress Versus Plastic Strain for Two Tests on Type 316L SS in Simulated J-13 Water at $\$ 3^{\circ} \mathrm{C}\left(\dot{\varepsilon}=1 \times 10^{-7} \mathrm{~s}^{-1}\right)$ 


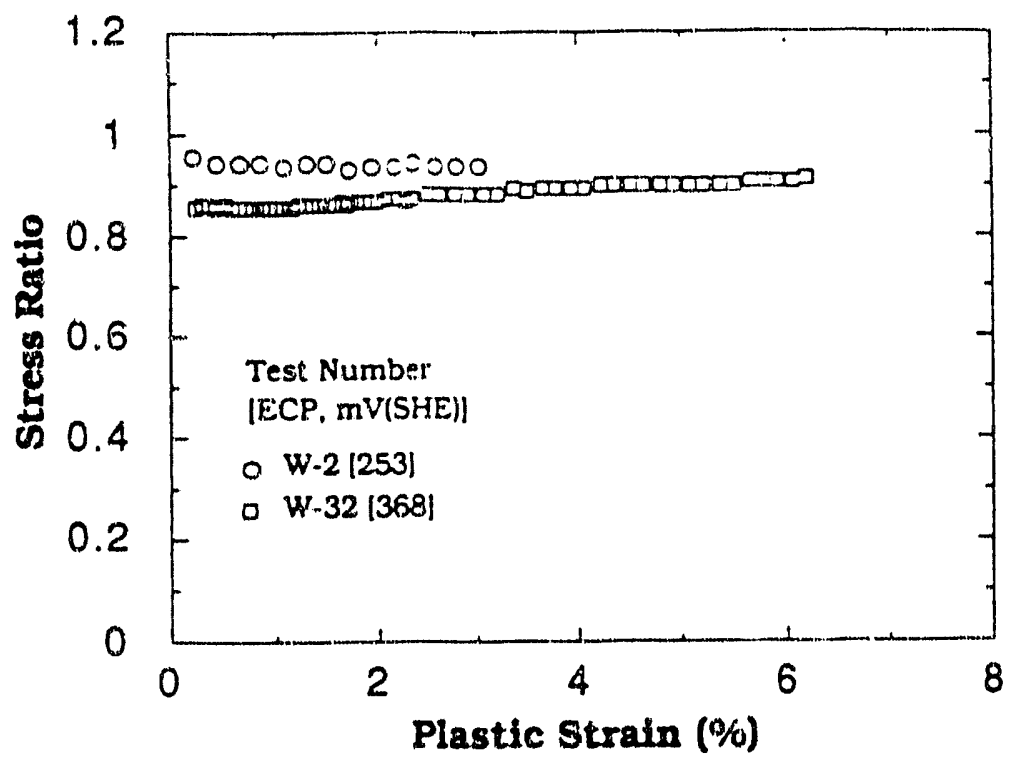

Fig. 46. Compartson of Stress Versus Plastic Strain for nwo Tests on Incoloy 825 in Simulated $\mathrm{J}-13$ Water at $93^{\circ} \mathrm{C}\left(\varepsilon=1 \times 10^{-7} \mathrm{~s}^{-1}\right)$

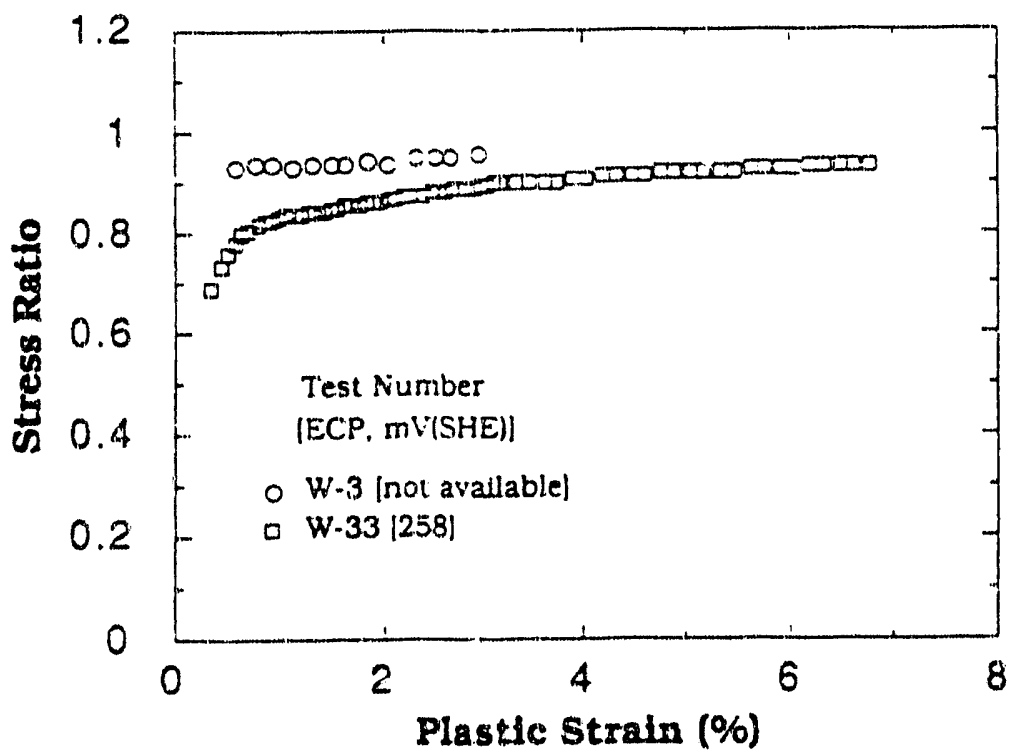

Fig. 47. Compartson of Stress Versus Plastic Strain for Tue Tests on Cu-30N to Simulated I-13 water ai $93^{\circ} \mathrm{C}\left(\varepsilon=1 \times 10^{-7} \mathrm{~s}^{-1}\right)$ 


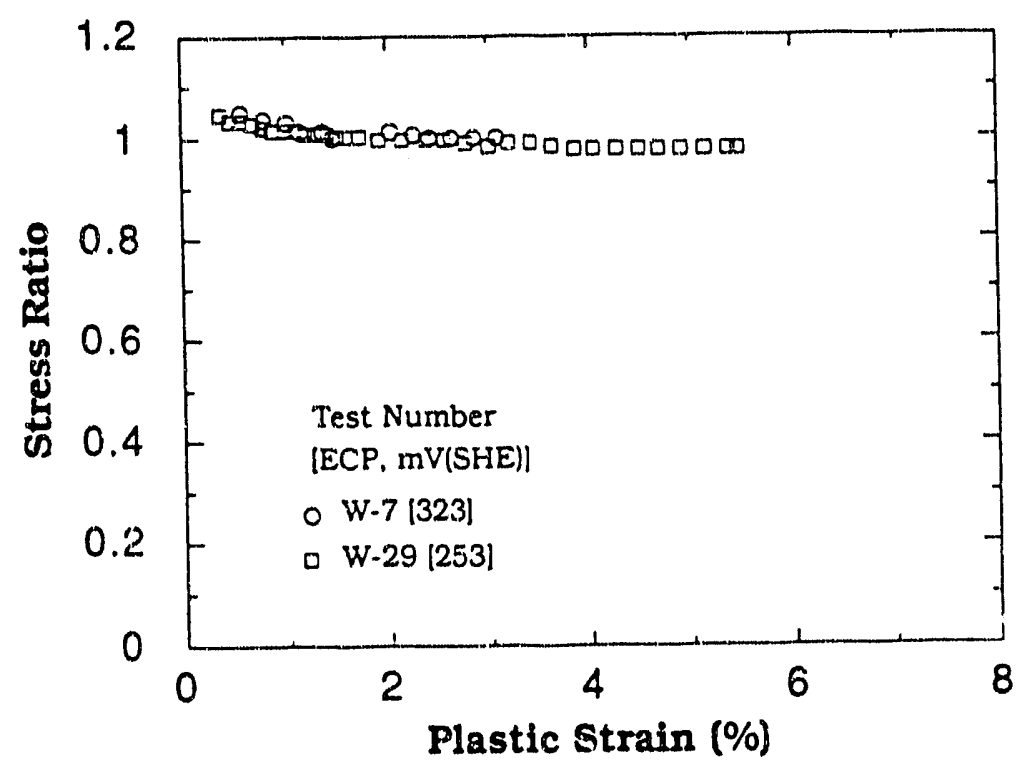

Fig. 48. Compartson of Stress Versus Plastic Strain for Two Tests on $\mathrm{Cu}-7 \mathrm{Al}$ in Simulated $J-13$ Water at $93^{\circ} \mathrm{C}\left(\dot{\varepsilon}=1 \times 10^{-7} \mathrm{~s}^{-1}\right)$

We can examine the ranking of the five alloys in terms of stress and strain ratios estimated from the dial-indicator and extensometer measurements of displacements in the specimen from tests $W-23 / W-33$. Figure 49 is a plot of stress ratio versus plastic strain for the five candidate materials based upon the dial indicator readings. In this plot, we have included the duplicate test results for Type 304L SS, Incoloy 825, and Cu-30Ni (eepresented by the same symbol for each material). On the basis of this plot, the ranking of materials in order of increasing resistance to cracking is Type 304L SS < Type 316L SS $<$ Incoloy $825<\mathrm{Cu}-30 \mathrm{Ni}<\mathrm{Cu}-7 \mathrm{Al}$. These results are similar to the ranking for tests $\mathrm{W}-$ $2 / \mathrm{W}-7$ except that Incoloy 825 appears to be slightly inferior to $\mathrm{Cu}-30 \mathrm{Ni}$ in cracking resistance. A similar ranking is observed when the strain ratio is used (Fig. 50). The slightly superior SCC resistance of $\mathrm{Cu}-30 \mathrm{Ni}$ compared to that of Incoloy 825 can also be seen from Tests $\mathrm{W}-32$ and $\mathrm{W}-33$, where specimen displacement measurements were made with the LVDT extensometer. Both of the tests for this case were interrupted at $=12.0 \%$ elongation strains. The slightly superior $\mathrm{SCC}$ resistance of $\mathrm{Cu}-30 \mathrm{Ni}$, compared to that of Incoloy, in terms of both stress and strain ratios is shown in Fig. 51. It is important to note that the above ranking for the five materials is again not affected by the method of computing strain, as is evidenced from Figs. 52 and 53 , where stress and strain ratios are estimated from the measured plastic strain and strain rate. The significance of the slight differences in resistance to SCC observed in this study for the two competing matertals. (Incoloy 825 and $\mathrm{Cu}-30 \mathrm{Ni}$ ) requires a better understanding of the stress and strain ratios. as well as contirmation by otiner types of tests such as íraciure-mecinanicis Cón tésts. 


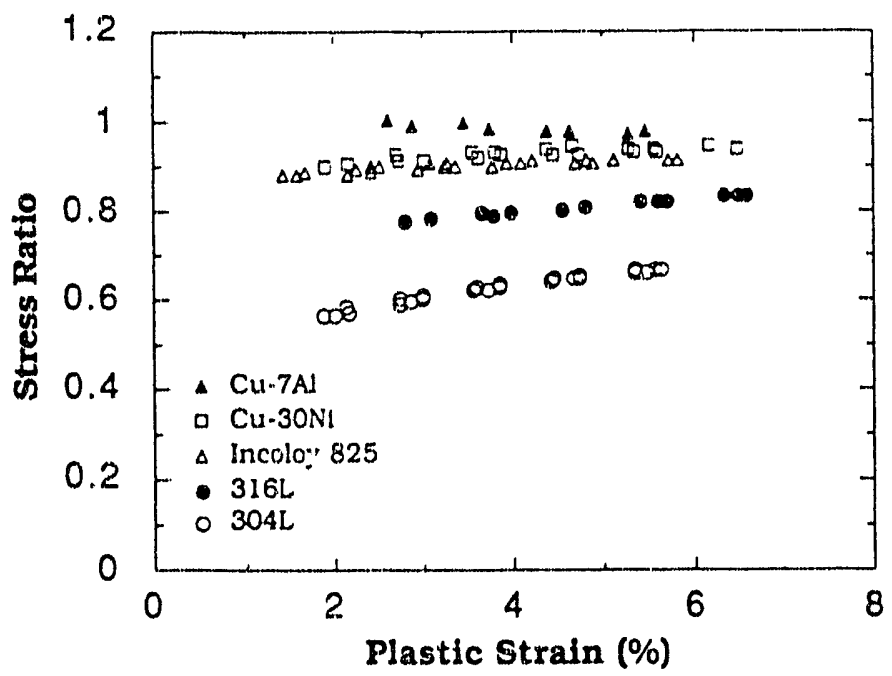

Fig. 49. Relative Cracking Susceptibility of Five Alloys in Simulated $J-13$ Water at $9.3^{\circ} \mathrm{C}$. Cracking susceptibulty is expressed in terms of the nominal stress ratio [Eq. (13)] where lower values imply greater cracking susceptiblity. Stress ratio is based on estimating strains $n$ the SSRT specimens by means of a dial indicator $\left(\dot{\varepsilon}=1 \times 10^{-7} s^{-1}\right)$.

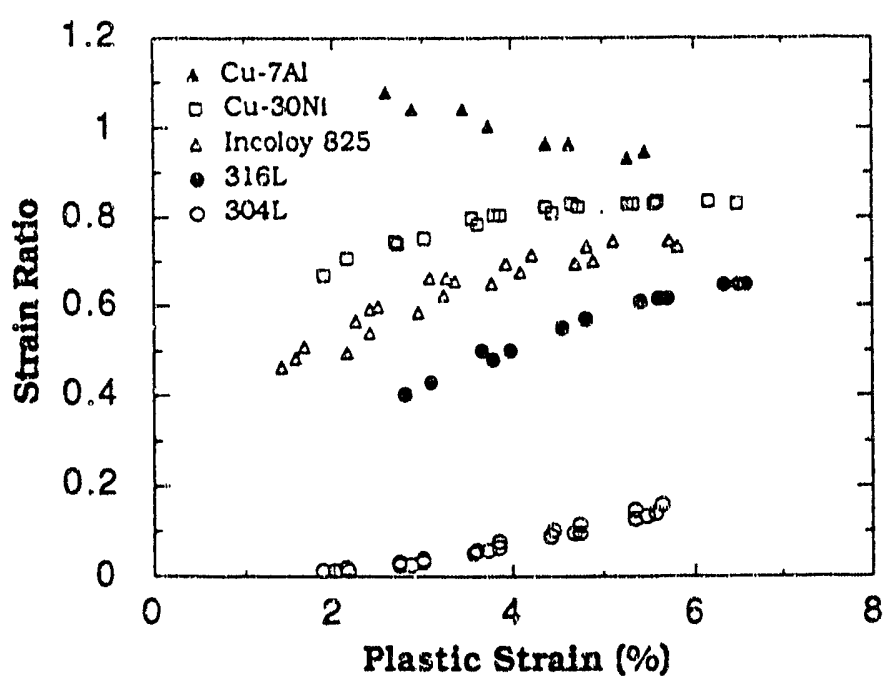

Fig. 50. Relative Cracking Susceptibility of Five Alloys in Simulated $J-13$ Water at $93^{\circ} \mathrm{C}$. Cracking susceptibulty is expressed in terms of the norninal strain ratto [Eq. (17)] where lower values imply greater cracking susceptibulty. Strain ratio is based on estumating strains in the $\bar{S} \bar{S} \bar{T}$ spectmens by means of a dital indicator $\left(\varepsilon=1 \times 10^{-7} \mathrm{~s}\right)$. 


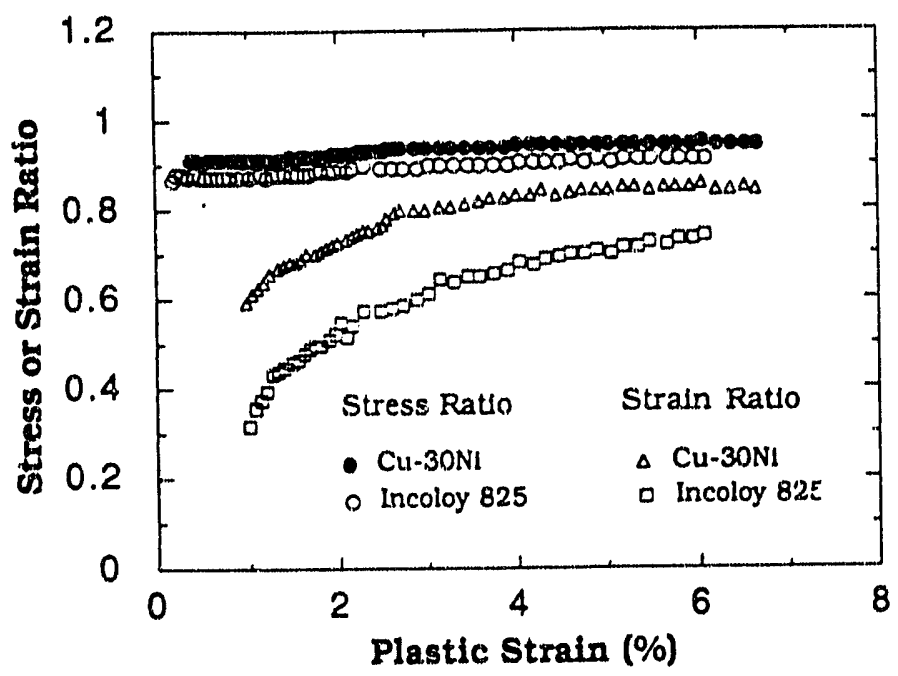

Flg. 51. Cracking Susceptlbuty of Incoloy 825 and Cu-30NI in Terms of the Stress Ratio [Eq. (13)] or the Strain Ratio [Eq. (17)] in $\mathrm{J}-13$ Water at $93^{\circ} \mathrm{C}$ Where Lower Values Imply Greater Susceptlbutty. The stress and strain ratios are based on estimation of strains in the SSRT specimens by means of an LVDT extensometer.

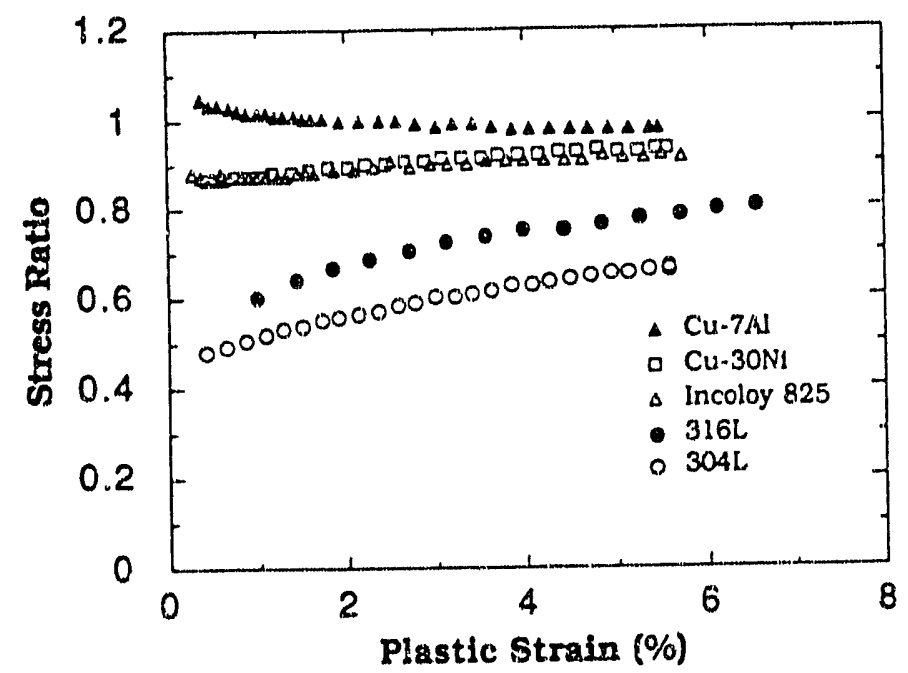

Fig. 52. Relative Cracking Susceptibility of Fue Alloys in Simulated $J-13$ Water at $93^{\circ} \mathrm{C}$. Cracking susceptibulty is expressed in terms of the nominal stress ratto [Eq. (13)] where lower values imply greater cracking susceptlbitity. Stress ratio is based on estimating stiuins to the sarr spectmens by means of the strainrate method [Eqs. (15) and (16)]. 


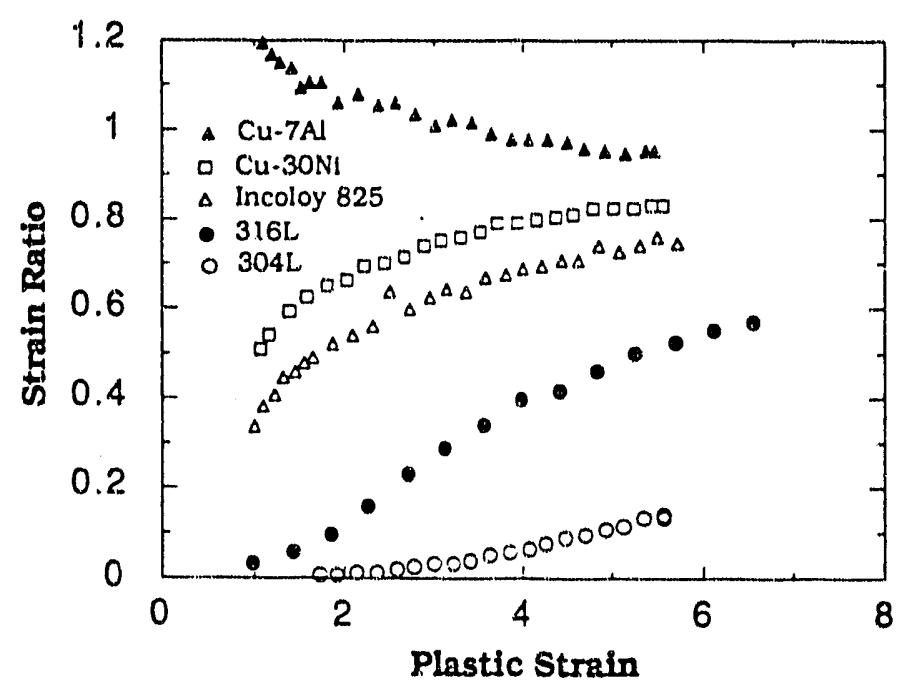

Fig. 53. Relative Cracking Suscepttbulty of Five Alloys in Simulated $J-13$ Water at $93^{\circ} \mathrm{C}$. Cracking susceptibility is expressed in terms of the nominal strain ratio [Eq. (13)] where lower values imply greater cracking susceptiblity. Stress ratio is based on estimating strains in the SSRT specimens by means of the strain-rate method [Eqs. (15) and (16)].

\subsubsection{Influence of Strain Rate on SCC}

Two tests (W-27 and W-28; see Table 15) have been performed at the slower strain rate of $5.0 \times 10^{-8} \mathrm{~s}^{-1}$, one on $\mathrm{Cu}-30 \mathrm{NI}$ and another on $\mathrm{Cu}-7 \mathrm{Al}$. Comparison of the results with those obtained at the slightly higher strain rate of $10^{-7} \mathrm{~s}^{-1}$ showed no significant effects of strain rate on stress ratio. However, these tests show the potentlal for studying the effects of strain rate on cracking with the use of stress or strain ratios and hence for establishing whether the cracking is environmentally assisted.

\subsection{Preparation and Analyses of Test Solutions}

The effluent-water chemistries for the completed SSRI tests are reported in Tables 17-20. In test $w-1$, the concentrations of most of the species were higher by a factor of $\approx 20$ relative to J-13 water; however, the values for Ca and $\mathrm{Mg}$ were very low ( $<0.04 \mathrm{ppm}$ ) to prevent precipitation of slightly soluble compounds such as $\mathrm{CaCO}_{3}, \mathrm{CaF}_{2}, \mathrm{MgF}_{2}, \mathrm{CaSiO}_{3}$, and $\mathrm{MgSiO}_{3}$. The $\mathrm{HCO}_{3}^{-}$concentration was obtalned by bubbling a $12 \% \mathrm{CO}_{2}-20 \% \mathrm{O}_{2}-68 \%$ $\mathrm{N}_{2}$ gas mixture through the feedwater and maintaining a 5 psig overpressure in the feedwater tank. This gas mixture also set the dissolved-oxygen concentration of the feedwater at $\approx 7-8 \mathrm{ppm}$. The $\mathrm{HCO}_{3}^{-}$concentration in the effluent water was higher by a factor of only $\approx 6$ than that in $\mathrm{J}-13$ water because some of the $\mathrm{CO}_{2}$ escapes into the atrnosphere in the test vessel at $93^{\circ} \mathrm{C}$. The relattvely high concentration of sodium silicate and low concentration of $\mathrm{HCO}_{3}^{-}$are reflected in the rather high $\mathrm{pH}$ value of $\approx 9.2$. Precipitation of silica compounds on the Incoloy 825 SSRT specimen and the test vessel also occurred with this nominal $20 \mathrm{x}$ water chemistry. 
Table 17. Chemical Compositton ${ }^{a}$ of Effluent Water from SSRTs on Candidate Waste Container Materials, Tests W-1 through W-9

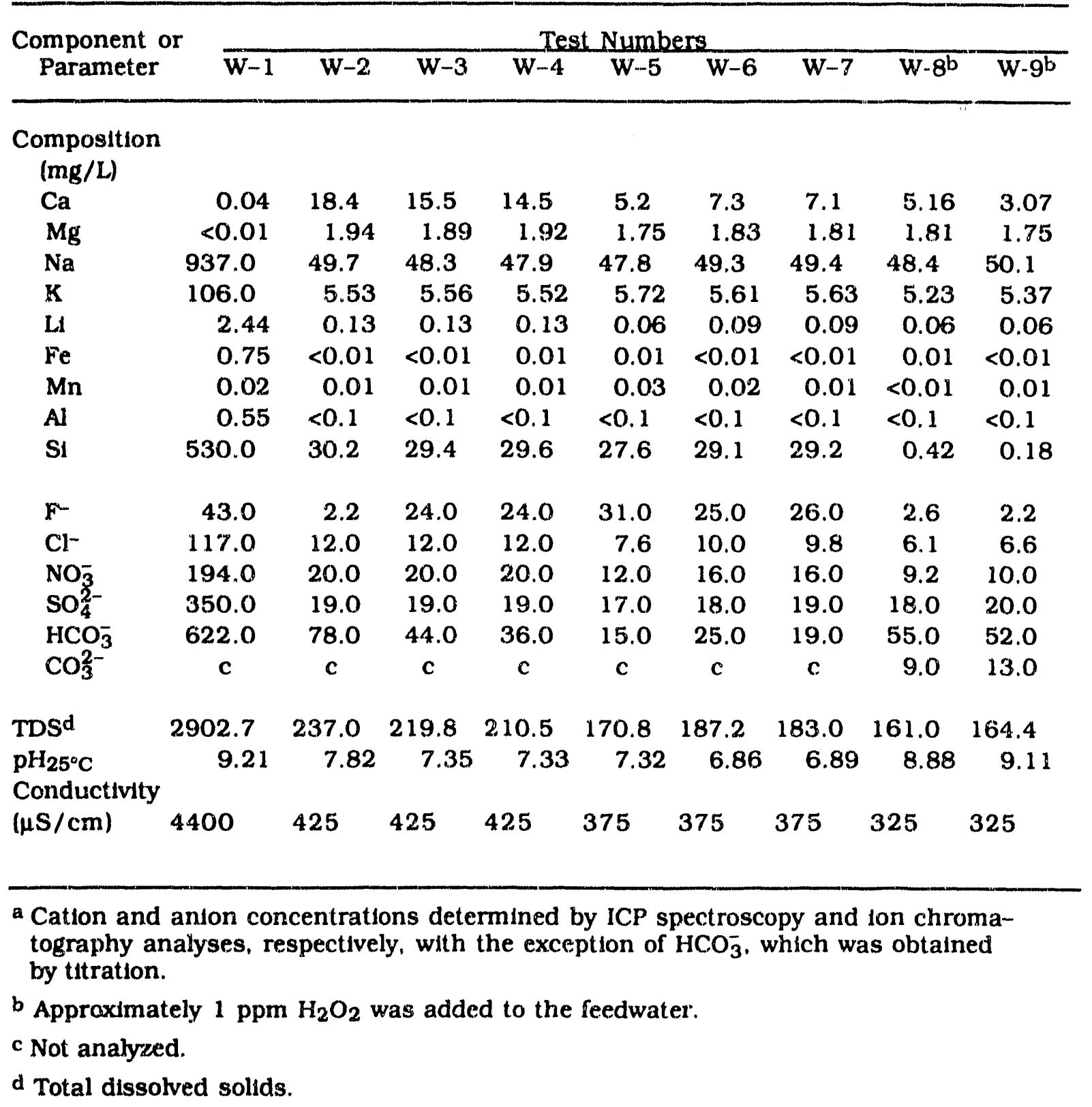


Table 18. Chemical Composition a of Effluent Water from SSRTs on Candidate Waste Container Materials, Tests W-10 through W-18

\begin{tabular}{|c|c|c|c|c|c|c|c|c|c|}
\hline \multirow{2}{*}{$\begin{array}{l}\text { Component or } \\
\text { Parameter }\end{array}$} & \multicolumn{9}{|c|}{ Test Numbers } \\
\hline & $\overline{w-10}$ & $w-11$ & $w-12$ & $w-13$ & $W-14$ & $w-15$ & $w-16$ & $w-17$ & $W-18$ \\
\hline \multicolumn{10}{|l|}{$\begin{array}{l}\text { Composition } \\
(\mathrm{mg} / \mathrm{L})\end{array}$} \\
\hline $\mathrm{Ca}$ & 10.2 & 11.0 & 10.5 & 10.9 & 10.6 & 10.6 & 10.8 & 10.8 & 10.5 \\
\hline $\mathbf{M g}$ & 1.79 & 1.84 & 1.78 & 2.08 & 2.04 & 2.19 & 2.07 & 2.06 & 2.08 \\
\hline $\mathrm{Na}$ & 51.6 & 49.6 & 47.4 & 55.6 & 51.6 & 52.7 & 52.0 & 51.8 & 49.6 \\
\hline $\mathbf{K}$ & 5.23 & 5.33 & 5.11 & 6.09 & 5.43 & 5.96 & 5.86 & 5.41 & 5.88 \\
\hline $\mathrm{L}$ & 0.06 & 0.06 & 0.05 & 0.07 & 0.06 & 0.07 & 0.06 & 0.06 & 0.06 \\
\hline $\mathrm{Fe}$ & $<0.01$ & $<0.01$ & $<0.01$ & $<0.01$ & $<0.01$ & $<0.01$ & $<0.01$ & $<0.01$ & $<0.01$ \\
\hline $\mathbf{M n}$ & $<0.01$ & $<0.01$ & $<0.01$ & $<0.01$ & $<0.01$ & $<0.1$ & $<0.1$ & $<0.1$ & $<0.1$ \\
\hline Al & $<0.1$ & $<0.1$ & $<0.1$ & $<0.1$ & $<0.1$ & $<0.1$ & $<0.1$ & $<0.1$ & $<0.1$ \\
\hline Si & 0.13 & $<0.1$ & $<0.1$ & b & $\mathrm{b}$ & $\mathrm{b}$ & b & b & $\mathrm{b}$ \\
\hline $\mathrm{NiC}^{\mathrm{C}}$ & 0.46 & 1.66 & 1.23 & 1.06 & 0.85 & 0.94 & 1.41 & 1.78 & 1.65 \\
\hline $\mathrm{F}$ & 2.0 & 1.9 & 1.8 & 2.2 & 2.1 & 2.0 & 2.1 & 2.1 & 2.1 \\
\hline $\mathrm{Cl}^{-}$ & 6.5 & 6.4 & 5.8 & 6.9 & 5.9 & 6.4 & 6.2 & 5.9 & 6.6 \\
\hline $\mathrm{NO}_{3}^{-}$ & 10.0 & 10.0 & 9.9 & 11.0 & 10.0 & 10.0 & 10.0 & 10.0 & 10.0 \\
\hline $\mathrm{SO}_{4}^{2-}$ & 19.0 & 18.0 & 17.0 & 21.0 & 20.0 & 20.0 & 19.0 & 20.0 & 20.0 \\
\hline $\mathrm{HCO}_{3}^{-}$ & 128.0 & 133.0 & 128.0 & 137.0 & 125.0 & 130.0 & 133.0 & 133.0 & 131.0 \\
\hline $\mathrm{CO}_{3}^{2-}$ & d & d & $\mathrm{d}$ & $<6.0$ & $<6.0$ & $<6.0$ & $d$ & $\mathrm{~d}$ & $<6.0$ \\
\hline TDSe & 234.9 & 238.8 & 228.6 & 254.0 & 233.6 & 241.0 & 242.5 & 242.8 & 239.5 \\
\hline $\mathrm{pH}_{25^{\circ} \mathrm{C}}$ & 8.51 & 7.98 & 7.76 & 8.33 & 8.34 & 8.31 & 8.26 & 8.10 & 8.39 \\
\hline $\begin{array}{l}\text { Conductivity } \\
(\mu \mathrm{S} / \mathrm{cm})\end{array}$ & 375 & 370 & 350 & 365 & 370 & 395 & 385 & 405 & 400 \\
\hline
\end{tabular}

a Cation and anion concentrations determined by ICP spectroscopy and ion chromatography analyses, respectively, with the exception of $\mathrm{HCO}_{3}^{-}$, which was obtained by titration.

b Not analyzed: Si no longer added to the feedwater.

c Nickel is present from corrosion of the nickel test vessel.

d Not detected.

e Total dissolved solids. 
Table 19. Chemical Composition a of Efluent Water from SSRTs on Candidate Waste Container Materials, Tests W-19 through W-27

\begin{tabular}{|c|c|c|c|c|c|c|c|c|c|}
\hline \multirow{2}{*}{$\begin{array}{l}\text { Component or } \\
\text { Parameter }\end{array}$} & \multicolumn{9}{|c|}{ Test Numbers } \\
\hline & $\overline{W-19}$ & $\mathrm{w}-20$ & $w-21$ & $w-22$ & $w-23$ & $w-24$ & w-25 & $w-26$ & W-27 \\
\hline \multicolumn{10}{|l|}{$\begin{array}{l}\text { Composition } \\
(\mathrm{mg} / \mathrm{L})\end{array}$} \\
\hline $\mathrm{Ca}$ & 11.0 & 10.5 & 10.6 & 10.7 & 10.5 & 10.5 & 10.8 & 10.8 & 10.8 \\
\hline $\mathrm{Mg}$ & 2.13 & 2.15 & 2.32 & 2.31 & 2.17 & 1.91 & 2.22 & 1.88 & 1.99 \\
\hline $\mathrm{Na}$ & 50.3 & 50.1 & 50.9 & 51.0 & 50.5 & 50.7 & 51.5 & 50.9 & 50.9 \\
\hline $\mathbf{K}$ & 5.71 & 5.45 & 5.32 & 5.49 & 5.58 & 5.36 & 5.48 & 5.38 & 5.39 \\
\hline $\mathbf{L I}$ & 0.05 & 0.05 & 0.06 & 0.06 & 0.06 & 0.06 & 0.06 & 0.06 & 0.06 \\
\hline $\mathrm{Fe}$ & $<0.01$ & $<0.01$ & $<0.01$ & $<0.01$ & $<0.01$ & $<0.01$ & $<0.01$ & $<0.01$ & $<0.01$ \\
\hline Mn & $<0.01$ & $<0.01$ & $<0.01$ & $<0.01$ & $<0.01$ & $<0.01$ & $<0.01$ & $<0.01$ & $<0.01$ \\
\hline Al & $<0.1$ & $<0.1$ & $<0.1$ & $<0.1$ & $<0.1$ & $<0.1$ & $<0.1$ & $<0.1$ & $<0.1$ \\
\hline Si & $\mathrm{b}$ & $\mathrm{b}$ & $\mathrm{b}$ & $\mathrm{b}$ & $b$ & b & b & b & b \\
\hline $\mathrm{Ni}^{\mathrm{C}}$ & 1.54 & 0.83 & 1.22 & 2.23 & 1.13 & 1.48 & 1.69 & 1.13 & 2.13 \\
\hline $\mathrm{F}^{-}$ & 2.1 & 2.2 & 2.0 & 2.0 & 2.1 & 2.0 & 2.2 & 2.2 & 2.1 \\
\hline $\mathrm{Cl}^{-}$ & 6.6 & 7.1 & 7.0 & 6.4 & 6.2 & 6.5 & 6.5 & 6.4 & 6.6 \\
\hline $\mathrm{NO}_{3}^{-}$ & 11.0 & 11.0 & 12.0 & 10.0 & 10.0 & 11.0 & 12.0 & 12.0 & 13.0 \\
\hline $\mathrm{SO}_{4}^{2--}$ & 20.0 & 20.0 & 22.0 & 20.0 & 19.0 & 18.0 & 20.0 & 18.0 & 19.0 \\
\hline $\mathrm{HCO}_{3}^{-}$ & 134.0 & 134.0 & 133.0 & 130.0 & 133.0 & 137.0 & 141.0 & 139.0 & 142.0 \\
\hline $\mathrm{CO}_{3}^{2-}$ & $<6.0$ & - & $<6.0$ & $<6.0$ & $\mathrm{~d}$ & $<6.0$ & d & d & d \\
\hline TDSe & 244.4 & 243.3 & 246.4 & 240.0 & 241.1 & 244.5 & 253.5 & 247.8 & 236.0 \\
\hline $\mathrm{pH}_{25^{\circ} \mathrm{C}}$ & 8.36 & 8.24 & 8.35 & 8.31 & 8.26 & 8.35 & 8.18 & 8.28 & 8.23 \\
\hline \multicolumn{10}{|l|}{ Conductivity } \\
\hline$\mu \mathrm{S} / \mathrm{cm}$ & 405 & 410 & 400 & 395 & 385 & 395 & 375 & 375 & 380 \\
\hline
\end{tabular}

a Cation and anion concentrations determined by ICP spectroscopy and ion chromatography analyses, respectively, with the exception of $\mathrm{HCO}_{3}^{-}$, which was obtained by titration.

b Not analyzed: Si no longer added to the feedwater.

c Nickel is present from corrosion of the nickel test vessel.

d Not detected.

e Total dissolved solids. 
Table 20. Chemical Composition a of Effluent Water from SSRT's on Candidate Waste Container Materials, Tests W-28 through W-33

\begin{tabular}{|c|c|c|c|c|c|c|}
\hline \multirow{2}{*}{$\begin{array}{l}\text { Component or } \\
\text { Parameter }\end{array}$} & \multicolumn{6}{|c|}{ Test Numbers } \\
\hline & $w-28$ & $w-29$ & $w-30$ & $w-31$ & $w-32$ & w-33 \\
\hline \multicolumn{7}{|l|}{$\begin{array}{l}\text { Composition } \\
(\mathrm{mg} / \mathrm{L})\end{array}$} \\
\hline $\mathrm{Ca}$ & 10.8 & 11.0 & 10.4 & 10.6 & 10.3 & 10.4 \\
\hline $\mathrm{Mg}$ & 1.85 & 1.86 & 1.83 & 1.78 & 1.79 & 1.76 \\
\hline $\mathrm{Na}$ & 50.5 & 50.4 & 51.0 & 50.3 & 49.5 & 50.0 \\
\hline $\mathbf{K}$ & 5.46 & 5.86 & 7.77 & 5.45 & 5.32 & 5.32 \\
\hline $\mathrm{LI}$ & 0.06 & 0.06 & 0.06 & 0.06 & 0.06 & 0.06 \\
\hline $\mathrm{Fe}$ & $<0.01$ & $<0.01$ & $<0.01$ & $<0.01$ & $<0.01$ & $<0.01$ \\
\hline$M n$ & $<0.01$ & $<0.01$ & $<0.01$ & $<0.01$ & $<0.01$ & $<0.01$ \\
\hline $\mathrm{Al}$ & $<0.1$ & $<0.1$ & $<0.1$ & $<0.1$ & $<0.1$ & $<0.1$ \\
\hline SI & $b$ & $\mathrm{~b}$ & $\mathrm{~b}$ & $\mathrm{~b}$ & $\mathrm{~b}$ & $\mathrm{~b}$ \\
\hline $\mathrm{Ni}^{\mathrm{C}}$ & 1.77 & 2.22 & 2.47 & 1.24 & 1.93 & 1.97 \\
\hline$F^{2}$ & 2.2 & 2.3 & 2.0 & 2.1 & 2.2 & 2.1 \\
\hline $\mathrm{Cl}^{-}$ & 6.4 & 7.1 & 9.4 & 7.1 & 7.1 & 7.1 \\
\hline $\mathrm{NO}_{3}^{-}$ & 12.0 & 12.0 & 12.8 & 12.6 & 12.6 & 12.9 \\
\hline $\mathrm{SO}_{4}^{2-}$ & 18.0 & 18.0 & 19.9 & 19.5 & 19.7 & 20.0 \\
\hline $\mathrm{HCO}_{3}^{-}$ & 141.0 & 140.0 & 138.0 & 135.0 & 134.0 & 134.0 \\
\hline $\mathrm{CO}_{3}{ }^{2-}$ & $\mathrm{d}$ & $d$ & $d$ & $\mathrm{~d}$ & $\mathrm{~d}$ & $\mathrm{~d}$ \\
\hline TDSe & 262.0 & 250.9 & 255.7 & 245.8 & 244.5 & 245.7 \\
\hline $\mathrm{pH}_{25^{\circ} \mathrm{C}}$ & 8.12 & 8.11 & 8.22 & 8.11 & 8.01 & 7.97 \\
\hline Conductivity & & & & & & \\
\hline$(\mu \mathrm{S} / \mathrm{cm})$ & 385 & 395 & 395 & 375 & 370 & 380 \\
\hline \multicolumn{7}{|c|}{$\begin{array}{l}\text { a Cation and anion concentrations determined by ICP spectroscopy and ion chroma- } \\
\text { tography analyses, respectively, with the exception of } \mathrm{HCO}_{3}^{-} \text {, which was obtained } \\
\text { by titration. }\end{array}$} \\
\hline \multicolumn{7}{|c|}{ b Not analyzed; Si no longer added to the feedwater. } \\
\hline \multicolumn{7}{|c|}{$\begin{array}{l}\text { c Nickel is present from corrosion of the nickel test vessel. } \\
\text { d Not detected. }\end{array}$} \\
\hline d Not detected. & & & & & & \\
\hline Total dissolv & s. & & & & & \\
\hline
\end{tabular}


In tests $\mathrm{W}-2 / \mathrm{W}-7$, the effluent-water chemistry more closely approximated that of $\mathrm{J}$ 13 water; however, the concentrations of some of the anlons $\left(\mathrm{F}^{-}, \mathrm{Cl}^{-}\right.$, and $\left.\mathrm{NO}_{3}^{-}\right)$, were higher by factors of $\approx 2-20$ and the concentrattons of $\mathrm{HCO}_{3}^{-}$were lower by factors of $\approx 2-4$. The 30-ppm Si $\approx 80 \mathrm{ppm}\left(\approx 80 \mathrm{ppm} \mathrm{SiO}_{3}^{2-}\right)$ and 78-19-ppm $\mathrm{HCO}_{3}^{-}$in the feedwater were obtained by adding $\mathrm{Na}_{2} \mathrm{SiO}_{3}$ and bubbling with a $12 \% \mathrm{CO}_{2}-20 \% \mathrm{O}_{2}-68 \% \mathrm{~N}_{2}$ gas mixture, as in test $\mathrm{W}-1$. The $\mathrm{pH}_{25} 5^{\circ} \mathrm{C}$ of the effluent water ranged from 6.9 to 7.8 in these tests. Nickel from corrosion of the test vessels was also detected in the effluent water (typically $<2 \mathrm{ppm}$ ). To increase the $\mathrm{HCO}_{3}^{-}$concentration to the level in $\mathrm{J}-13$ water (1.e, to $\approx 143$ ppm), this species was added as $\mathrm{NaHCO}_{3}$ and the gas mixture in the feedwater tank was changed to $20 \% \mathrm{O}_{2}-80 \% \mathrm{~N}_{2}$ in Tests $\mathrm{W}-8$ and $\mathrm{W}-9$. Approximately 1 ppm of $\mathrm{H}_{2} \mathrm{O}_{2}$ was also added to the feedwater after sparging with the $\mathrm{O}_{2}-\mathrm{N}_{2}$ gas mixture. The measured $\mathrm{H}_{2} \mathrm{O}_{2}$ concentration in the effluent water was $\approx 0.2 \mathrm{ppm}$.

Beginning with test $\mathrm{W}-10, \mathrm{Na}_{2} \mathrm{SiO}_{3}$ was no longer added to the feedwater. The reason for this change was that although sllica solubility increases as temperature increases, the amount of material in solution depends on the phase (crystalline or amorphous) in equilibrium with the water, as well as on the nature and concentration of other species that are present. 11 The soluble form of silica is the monomeric species $\mathrm{Si}(\mathrm{OH})_{4}$. l.e., orthosilicic acid. Polysilicic acid with molecular weights, as $\mathrm{SiO}_{2}$, up to 100,000 amu and particle sizes $<50 \AA$ in diameter, as well as colloidal silica with a range of particle sizes, can also be present in the water.

The "solubility" values range from $\approx 100$ to $150 \mathrm{ppm}$ as $\mathrm{SIO}_{2}$ at $25^{\circ} \mathrm{C}$; at $\approx 100^{\circ} \mathrm{C}$, the range is $\approx 400$ to $500 \mathrm{ppm}$. At $25^{\circ} \mathrm{C}$, minimal solubility of amorphous silica $(\approx 100 \mathrm{ppm})$ occurs at $\mathrm{pH}=7$; at higher and lower $\mathrm{pH}$ values, the solubility increases. But impurities in the water can have a significant effect on the solubility of silica. For example, $\mathrm{Al}_{2} \mathrm{O}_{3}$ or $\mathrm{AlCl}_{3} \cdot\left(6 \mathrm{H}_{2} \mathrm{O}\right)$ can adsorb on sllica and cause it to precipitate (1.e.. decrease the $\mathrm{SiO}_{2}$ concentrations to $<6 \mathrm{ppm}$ ). This readily soluble hydrated salt was used to add $\mathrm{Al}^{3+}$ to simulated $\mathrm{J}-13$ water in our experiments. Also, magnesium ion converts soluble silica (amorphous) to a magnesium silicate and also decreases the solubility. Organic impurities, although very low in our delonized water, can either increase or decrease sllica solubility. Because silicates are commonly used as corrosion inhibitors in low-temperature systems, 12,13 it is unlikely that they would contribute to SCC of the candidate materials in our test.s.

Although the effluent water chemistries in Tests $\mathrm{W}-\mathrm{-8}$ and $\mathrm{W}-9$ more closely approximate $\mathrm{J}-13$ water (with the exception of $\mathrm{Si}$ ), the $\mathrm{HCO}_{3}^{-}$concentration was still somewhat lower $\left(\approx 50\right.$ versus $143 \mathrm{ppm}$ ) and the $\mathrm{pH}_{25}{ }^{\circ} \mathrm{C}$ was considerably higher (8.9 to 9.1 versus 6.9). Because of the high $\mathrm{pH}, \mathrm{CaCO}_{3}$ precipitation occurred, as evidenced by the high $\mathrm{Ca}$ content of the scale deposit and the low Ca values in the efluent water of Tests $\mathrm{W}$ 8 and $W-9$ (Table 17 ) relative to the feedwater (3-5 versus $11 \mathrm{ppm}$ ).

In Tests $W-10 / W-23$, the fonic species were of the same formulation as that in the two previous tests, but a $12 \% \mathrm{CO}_{2}-20 \% \mathrm{O}_{2}-68 \% \mathrm{~N}_{2}$ cover gas was bubbled through the feedwater to achieve the desired dissolved oxygen concentration and to produce an "equillibrium" $\mathrm{CO}_{2}$ overpressure to stabilize the $\mathrm{HCO}_{3}^{-}$concentration and $\mathrm{pH}$ of the feedwater. As is evident in Tables $17-20$, the $\mathrm{HCO}_{3}^{-}$and $\mathrm{pH}_{25}{ }^{\circ} \mathrm{C}$ values in the effluent water range from 125 to $141 \mathrm{ppm}$ and 7.8 to 8.5 , respectively. The effuent $\mathrm{Ca}$ and $\mathrm{Mg}$ concentrations were virtually the same as in the feedwater, and very little deposition 
accurred on the SSRT specimens or the vessel wall in these tests. With the exception of the Si concentration $(<0.1 \mathrm{ppm})$, this water chemistry is a good simulation of the lonic and

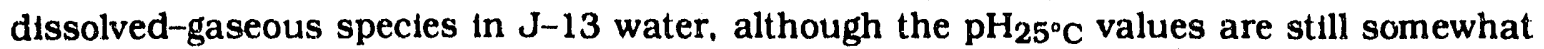
higher than the reported near-neutral value for $\mathrm{J}-13$ water. This, in part, can be attributed to some loss of $\mathrm{CO}_{2}$ to the gas phase above the water (i.e., air entrapped by a snug metal lid that fits on top of the test vessel) at ambient pressure. The effluent water analyses from tests $\mathrm{W}-10 / \mathrm{W}-23$ indicate that the feedwater can be made up in a reproducible manner.

Beginning with test $\mathrm{W}-10$, a pH electrode was incorporated into the test vessel to obtain in-situ values at the test temperature of $93^{\circ} \mathrm{C}$. The measured $\mathrm{pH}$ values at 25 and

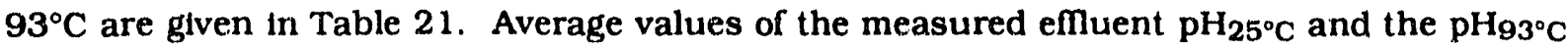
in the vessel for tests with the same feedwater chemistry (W-10/W-23) were 8.2 and 7.0, respectively, or approximately one $\mathrm{pH}$ unit on the basic side of neutral at the two

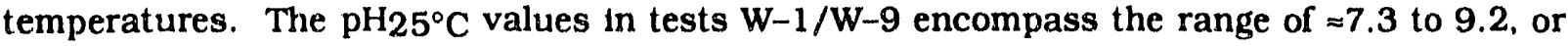
approximately one $\mathrm{pH}$ unit on either side of the $\mathbf{8 . 2}$ value for the water chemistry that was used in the majority of the SSRTs.

\subsection{Measurement of Electrochemical Potential}

The ECP of the insulated SSRT specimens was measured against an external $2 \times 10^{-4}$ $\mathrm{M} \mathrm{KCl} / \mathrm{AgCl} / \mathrm{Ag}$ reference electrode at regular intervals during the test. Beginning with test W-19, a small rod of the container alloy and a Pt wire were also inserted into the test vessel to obtain an independent measure of the ECP of the material and the $\mathrm{Pt}$, as well as of the SSRT specimen and the Ni vessel. The values for each electrode were plotted versus time, and the steady-state ECP values obtained from the plots are given in Table 22. Typical plots of the measured ECP of the SSRT specimens versus time are shown in Fig. 54 for Incoloy-825 and the $\mathrm{Cu}-6 \% \mathrm{Al}$ alloy in tests $\mathrm{W}-13$ and $\mathrm{W}-15$.

The measured values were also converted to the SHE scale. The SHE conversion potential for an external $\mathrm{AgCl} / \mathrm{Ag}$ reference electrode at $93^{\circ} \mathrm{C}$ as a function of $\mathrm{KCl}$ concentration is shown in Fig. 55 and was obtained from relations for the thermocell and liquid junction potentials. The calculated value for an electrolyte concentration of $2 \times 10^{-4}$ $M$ (obtained from the figure) is $+365 \mathrm{mV}$. An experimental SHE correction potential of $+378 \mathrm{mV}$ for this electrode was obtained agalnst a commonly used $\mathrm{AgCl} / \mathrm{Ag}$ reference electrode with $\mathrm{KCl}$ electrolyte concentration of $0.1 \mathrm{M}$. The latter value was used to convert the steady-state ECP values in Table 22 to the SHE scale. The influence of temperature on the SHE correction potential for the $2 \times 10^{-4} \mathrm{M} \mathrm{KCl} / \mathrm{AgCl} / \mathrm{Ag}$ reference electrode was also calculated, and the result is shown in Fig. 56.

The results in Table 22 indicate that the ECP values for the SSRT specimens range from $\approx 230$ to $310 \mathrm{mV}(\mathrm{SHE}$ ) for $\mathrm{Cu}$ and $\mathrm{Cu}$-base alloys and $\approx 320$ to $390 \mathrm{mV}$ (SHE) for the austenitic stainless steels and Incoloy-825 in nominally the same water chemistry (tests W-10/W-23). A comparison of these values with results for the corresponding alloys in tests $W-1 / W-9$ indicates that the ECP values are not strongly dependent on the water chemistry of these experiments. The ECP values of electrodes fabricated from the same materials as the SSRT specimens are also shown in Table 22 for tests $W-19 / W-23$. The ECP values of the unstrained austenitic steel electrodes are lower by $\approx 100 \mathrm{mV}$ than those of the SSRT specimens (strained electrodes). 
Table 21. $p H 25^{\circ} \mathrm{C}$ of Effluent Water and $\mathrm{pH} 93^{\circ} \mathrm{C}$ in Vessel during SSRTs in Simulated $J-13$ Watera

\begin{tabular}{lll}
\hline $\begin{array}{c}\text { Test } \\
\text { No. }\end{array}$ & $\begin{array}{c}\text { pH at } \\
25^{\circ} \mathrm{C}\end{array}$ & $\begin{array}{c}\text { pH at } \\
9^{\circ} \mathrm{Cb}\end{array}$ \\
\hline W-1 & 9.21 & - \\
W-2 & 7.82 & - \\
W-3 & 7.35 & - \\
W-4 & 7.33 & - \\
W-5 & 7.32 & - \\
W-6 & 6.86 & - \\
W-7 & 6.89 & - \\
W-8 & 8.88 & - \\
W-9 & 9.11 & - \\
W-10 & 8.51 & 7.70 \\
W-11 & 7.98 & 6.90 \\
W-12 & 7.76 & 6.95 \\
W-13 & 8.33 & 7.25 \\
W-14 & 8.34 & 7.10 \\
W-15 & 8.31 & 7.30 \\
W-16 & 8.26 & 7.20 \\
W-17 & 8.10 & 7.10 \\
W-18 & 8.39 & 7.15 \\
W-19 & 8.36 & 7.25 \\
W-20 & 8.24 & 7.30 \\
W-21 & 8.35 & 7.25 \\
W-22 & 8.31 & 6.95 \\
W-23 & 8.26 & 6.85 \\
W-24 & 8.35 & 6.95 \\
W-25 & 8.18 & 6.90 \\
W-26 & 8.28 & 6.90 \\
W-27 & 8.23 & 6.85 \\
W-28 & 8.12 & 6.80 \\
W-29 & 8.11 & 6.80 \\
W-30 & 8.22 & 6.85 \\
W-31 & 8.11 & 6.90 \\
W-32 & 8.01 & 6.55 \\
W-33 & 7.97 & 6.35 \\
\hline & & \\
\hline
\end{tabular}

a Water chemistries are given in Tables 17-20; nominally the same concentrations of tonic species were present in Tests W-10 to W-33.

b Neutral pH at $93^{\circ} \mathrm{C}$ is 6.18 .

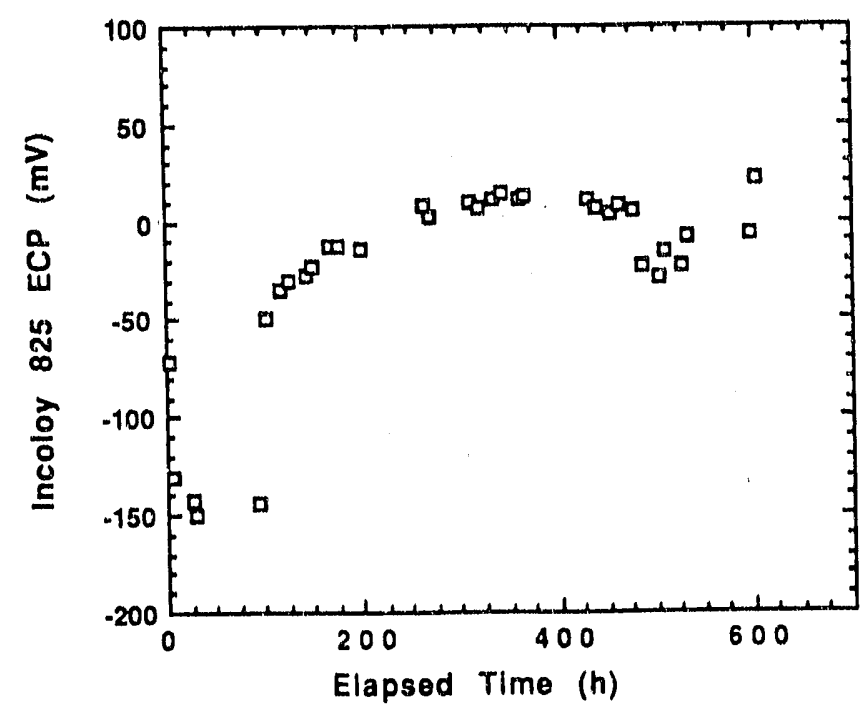

(a)

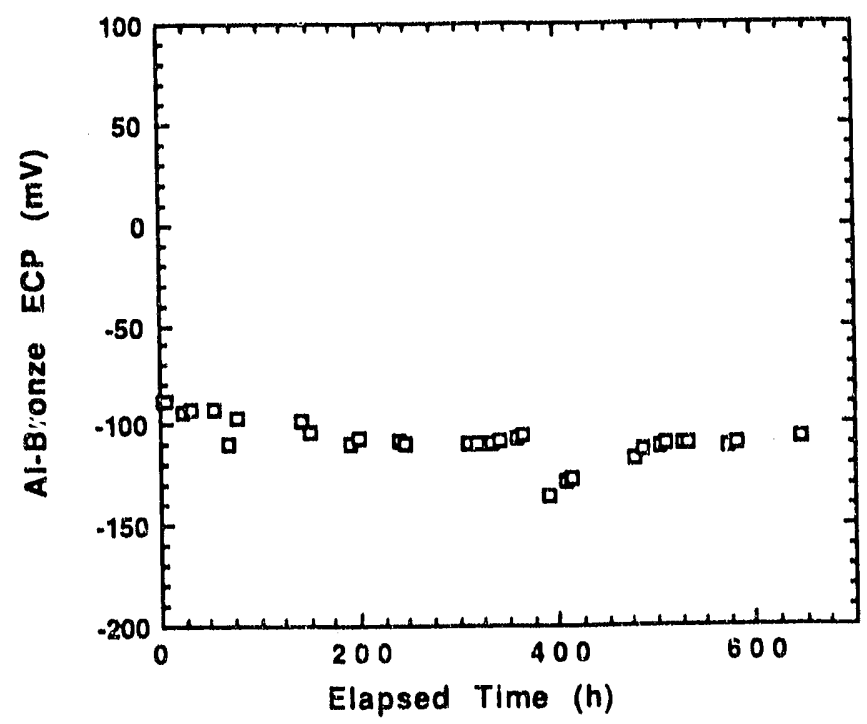

(b)

Fig. 54. Electrochemical Potential of (a) Incoloy 825 and (b) Cu-7\%Al Alloy SSRT Specimens at $93^{\circ} \mathrm{C}$ versus an External $2 \times 10^{-4} \mathrm{M} \mathrm{KCL} / \mathrm{AgCl} / \mathrm{Ag}$ Reference Electrode as a Function of Time during Tests $W-13$ and $W-15$ 
Table 22. Steady-State Electrochemical Potential of Candidate Waste Container Materials, Platinum, and Nickel Test Vessel during SSRTs in Simulated $\mathrm{J}-13$ Watera at $93^{\circ} \mathrm{C}$

\begin{tabular}{|c|c|c|c|c|c|c|}
\hline $\begin{array}{l}\text { Test } \\
\text { No. }\end{array}$ & Material & $\frac{\text { SSRT }}{\text { ECP'D }}$ & $\frac{\text { Specimen }}{\text { ECPC }}$ & $\begin{array}{l}\text { Electrode } \\
\text { ECP,c } \\
\text { mV(SHE) }\end{array}$ & $\begin{array}{l}\text { Platinum } \\
\text { ECP,c } \\
\text { mV(SHE) }\end{array}$ & $\begin{array}{c}\text { Nickel } \\
\text { ECP,c } \\
\text { mV(SḦE) }\end{array}$ \\
\hline $\mathbf{W}-1$ & In -825 & -145 & 233 & - & - & - \\
\hline$w-2$ & In-825 & -125 & 253 & - & - & - \\
\hline $\mathbf{w}-\mathbf{3}$ & $\mathrm{Cu}-30 \% \mathrm{NI}$ & - & - & - & - & - \\
\hline$W-4$ & $304 \mathrm{~L}$ SS & -68 & 310 & - & - & - \\
\hline $\mathbf{W}-\mathbf{5}$ & as & -75 & 303 & - & - & - \\
\hline$w-6$ & $316 \mathrm{~L}$ SS & -110 & 268 & - & - & - \\
\hline$w-7$ & $\mathrm{Cu}-6 \% \mathrm{Al}$ & -55 & 323 & - & - & - \\
\hline$w-8$ & $\mathrm{Ou}$ & -110 & 268 & & - & - \\
\hline W-9 & In-825 & -88 & 290 & - & - & - \\
\hline W-10 & $\mathrm{Cu}-30 \% \mathrm{NI}$ & -140 & 238 & - & - & - \\
\hline $\mathrm{W}-11$ & au & -95 & 283 & -- & - & - \\
\hline$w-12$ & $\mathrm{Ou}$ & -70 & 308 & - & - & - \\
\hline$w-13$ & In-825 & 5 & 383 & - & - & - \\
\hline$w-14$ & $\mathrm{Cu}-30 \% \mathrm{Ni}$ & -85 & 293 & - & - & - \\
\hline$w-15$ & $\mathrm{Cu}-6 \% \mathrm{Al}$ & -110 & 268 & - & - & - \\
\hline$W-16$ & $\mathrm{Cu}-6 \% \mathrm{Al}$ & -90 & 288 & - & - & - \\
\hline$w-17$ & $316 \mathrm{~L}$ SS & -15 & 363 & - & - & - \\
\hline$w-18$ & au & -90 & 288 & - & - & 322 \\
\hline$w-19$ & $316 \mathrm{~L}$ & -5 & 373 & 263 & 393 & 308 \\
\hline$w-20$ & $304 \mathrm{~L}$ & -35 & 343 & 253 & 398 & 312 \\
\hline$w-21$ & $\mathrm{Cu}-6 \% \mathrm{Al}$ & -150 & 228 & 248 & 388 & 293 \\
\hline$w-22$ & In-825 & -60 & 318 & 223 & 398 & 328 \\
\hline$w-23$ & $304 L$ & 10 & 388 & 238 & 468 & 278 \\
\hline$w-24$ & $316 \mathrm{~L}$ & -5 & 373 & 378 & 418 & 303 \\
\hline$w-25$ & $304 \mathrm{~L}$ & - & - & 268 & 443 & 308 \\
\hline W-26 & $304 \mathrm{~L}$ & -10 & 368 & 318 & 443 & 308 \\
\hline W-27 & $\mathrm{Cu}-30 \% \mathrm{Ni}$ & -110 & 268 & 263 & 468 & 318 \\
\hline W-28 & $\mathrm{Cu}-6 \% \mathrm{Al}$ & -120 & 258 & 263 & 458 & 308 \\
\hline$w-29$ & $\mathrm{Cu}-6 \% \mathrm{Al}$ & -125 & 253 & 263 & 423 & 308 \\
\hline$w-30$ & In-825 & -50 & 328 & 203 & 428 & 308 \\
\hline$w-31$ & $\mathrm{Cu}-30 \% \mathrm{NI}$ & -120 & 258 & 258 & 448 & 318 \\
\hline w-32 & In-825 & -10 & 368 & 208 & 478 & 323 \\
\hline w-33 & $\mathrm{Cu}-30 \% \mathrm{Ni}$ & -120 & 258 & 263 & 473 & 328 \\
\hline
\end{tabular}

a Water chemistries are given in Tables 17-20; nominally the same concentrations of Ionic species were present in Tests $\mathrm{W}-10$ to $\mathrm{W}-33$.

b Electrochemical potential of the electrically insulated CERT specimens measured against a $2 \times 10^{-4} \mathrm{M} \mathrm{KCl} / \mathrm{AgCl} / \mathrm{Ag}$ reference electrode.

c Electrochemical potential corrected to the standard hydrogen electrode (SHE) scale by the addition of $+378 \mathrm{mV}$ to the measured values. 


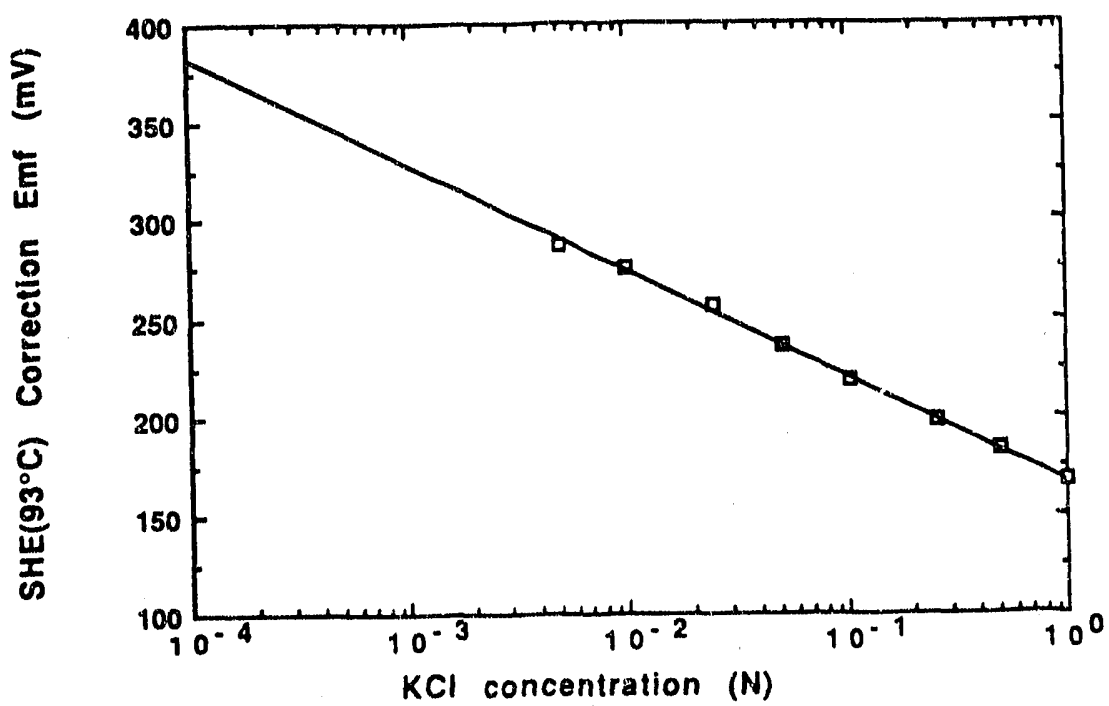

Fig. 55. Potential for Converting ECP Measurements from an External Suver Chloride Reference (SHE) Scale as a Function of the $\mathrm{KCl}$ Concentration from Relations for Thermocell and Liquid Junction Potentials

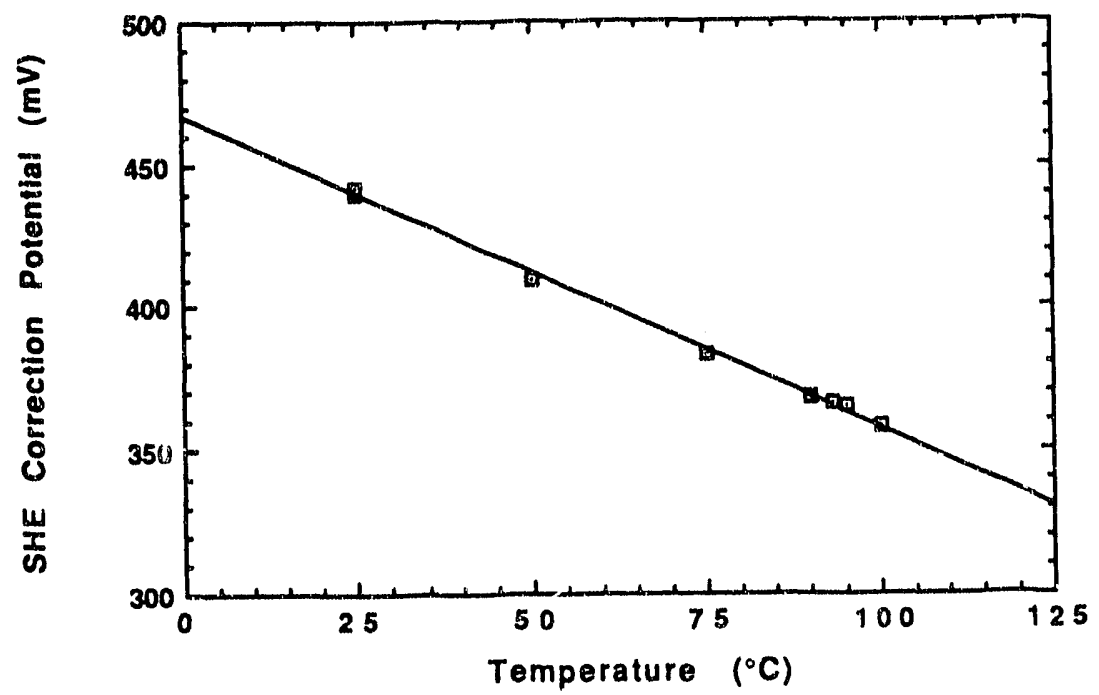

Fig. 56. Influence of Temperature on the Potential for Converting ECP Measurements with an External $2 \times 10^{-4} \mathrm{M} \mathrm{KCl} / \mathrm{AgCl} / \mathrm{Ag}$ Reference Electrode to the Standard Hydrogen Electrode (SHE) from Relations for Thermocell and Liquid Junction Potentials 


\section{Fracture-Mechanics Crack-Growth-Rate Tests}

\subsection{Experimental Procedures}

Compact tension (CT) specimens of $25.4 \mathrm{~mm}$ thickness were machined from 25.4-mmthick plates of Type 304L. S.S (Heat No. V70200). Type 316L SS (Heat No. 16650), and Incoloy 825 (Heat No. HH2125F). The materials were tested in the as-received millannealed condition without additional heat treatment. Elemental composition and mechanical properties of the materlals are shown in Tables 2-9.

Side grooves having a semicircular cross section were cut into both sides of the specimen to a depth of $1.27 \mathrm{~mm}$ to restrict crack growth to a single plane. The design of the CT specimens is in accordance with the ASTM specification E399, 14 except fo: the side grooves and six small threaded holes on the front face for instrumentation, as shown in Fig. 57. The stress intensity factors were calculated according to ASTM specification E399. The direction of crack extension was perpendicular to the short transverse thickness direction of the plates. Rolling direction of the plates was not provided by LLNL or the vendors. Metallographic examination of the materials did not reveal any clues for rolling direction.

The specimens were fatigue-precracked in air at room temperature for a length of $1.91 \mathrm{~mm}$ to introduce a sharp starter crack The initial machine notch measured from the load line was $17.78 \mathrm{~mm}$. An isosceles triangular loading waveform at a frequency of $1-2 \mathrm{~Hz}$. a load ratio $R$ (a ratio of minimum to maximum load) of 0.25 , an initial maximum stress intensity of $16.1 \mathrm{MPa} \cdot \mathrm{m}^{1 / 2}$ and a final maximum stress intensity of $17.5 \mathrm{MPa} \cdot \mathrm{m}^{1 / 2}$ was used for precracking. This final maximum stress intensity value is 7096 of initial peak stress intensity for the subsequent crack-growth-tests in a simulated $J-13$ well water.

The initial peak stress intensity value for the tests in the simulated J-13 well water was chosen to be about $25 \mathrm{MPa} \cdot \mathrm{m}^{1 / 2}$. Welding residual stresses are the most important driving force for cracks. Under these loads, the largest marginally detectable defects that would be created during the fabrication of a waste container would have assoctated stress intensity values approximately half the value chosen for these tests. which provides some conservatism.

The CGR tests were performed in a 5-L nickel vessel with a once-through flow system at a flow rate of $3 \mathrm{~mL} / \mathrm{min}$, under $1 \mathrm{~atm}$ pressure at $92-94^{\circ} \mathrm{C}$. The vessel was not hermetically sealed. The simulated $J-13$ well water was prepared from delonized highpuitty water (resistivity $\geq 16 \mathrm{M} \Omega \cdot \mathrm{cm}$ ) and reagent-grade purity saits of $\mathrm{CaSO}_{4}, \mathrm{Ca}\left(\mathrm{NO}_{3}\right)_{2}$. $\mathrm{CaCl}_{2}, \mathrm{FeCl}_{2}, \mathrm{~L}_{2} \mathrm{SO}_{4}, \mathrm{MgSO}_{4}, \mathrm{MnSO}_{4}, \mathrm{AlCl}_{3}, \mathrm{Na}_{2} \mathrm{CO}_{3}, \mathrm{NaHCO}_{3}, \mathrm{KHCO}_{3}, \mathrm{Na}_{2} \mathrm{SIO}_{3}$, and $\mathrm{HF}$. High-purtty mixed gas containing $20 \% \mathrm{O}_{2}, 12 \% \mathrm{CO}_{2}$, and $68 \% \mathrm{~N}_{2}$ was used as a cover gas at 3-5 psig to maintain the desired dissolved $\mathrm{O}_{2}$ and $\mathrm{HCO}_{3}^{-}$concentrations. Table 23 shows a typical composition of $J-13$ well water ${ }^{1}$ and analysis results for the simulated test solution used for the CGR tests. The test solution is a good simulation of the fonic and dissolved gaseous species in the $\mathrm{J}-13$ well water, with the exception of the SI concentration. Si was not adided to the test solution to avoid precipitation of silicate. Silicates are commonly used as corrosion inhibitors for low-temperature applications, 12.13 and it is considered unlikely that silicates would contribute to environmentally assisted crack growth of the test materials. The higher $\mathrm{pH}_{25^{\circ}} \mathrm{C}$ values for the emuent test solution are due to some loss of 
Table 23. Chemical Composition of $J-13$ Well Water and Test Solution

\begin{tabular}{lccc}
\hline & & \multicolumn{2}{c}{ Test Solution } \\
\cline { 4 - 4 } Species & $\begin{array}{c}\mathrm{J}-13 \\
\text { Analysis }\end{array}$ & Feed & Effluent \\
\hline $\begin{array}{c}\text { Composition } \\
(\mathrm{mg} / \mathrm{L})\end{array}$ & & & \\
$\mathrm{Ca}$ & 11.5 & $10.0-11.3$ & $10.1-11.5$ \\
$\mathrm{Mg}$ & 1.76 & $1.71-1.78$ & $1.72-1.88$ \\
$\mathrm{Na}$ & 45.0 & $48.3-48.8$ & $50.2-50.9$ \\
$\mathrm{~K}$ & 5.3 & $5.21-5.26$ & $5.32-5.44$ \\
$\mathrm{LI}$ & 0.06 & $0.057-0.058$ & $0.059-0.060$ \\
$\mathrm{Fe}$ & 0.04 & $<0.01$ & $<0.01$ \\
$\mathrm{Mn}$ & 0.001 & $<0.01$ & $<0.01$ \\
$\mathrm{Al}$ & 0.03 & $<0.1$ & $<0.1$ \\
$\mathrm{Si}$ & 30.0 & $\mathrm{a}, \mathrm{b}$ & $\mathrm{a} . \mathrm{b}$ \\
$\mathrm{Cu}$ & $\mathrm{b}$ & $<0.01$ & $<0.01$ \\
$\mathrm{Ni}^{-}$ & $\mathrm{b}$ & $<0.02$ & $1.61-4.66$ \\
$\mathrm{~F}^{-}$ & 2.1 & $2.02-2.10$ & $2.03-2.16$ \\
$\mathrm{Cl}^{-}$ & 6.4 & $6.68-6.94$ & $6.75-7.21$ \\
$\mathrm{SO}_{4}^{2-}$ & 18.1 & $19.3-20.5$ & $20.4-20.9$ \\
$\mathrm{NO}_{3}^{-}$ & 10.1 & $11.7-12.7$ & $12.7-13.1$ \\
$\mathrm{HCO}_{3}^{-}$ & 143.0 & $127-129.5$ & $132.2-141$ \\
$\mathrm{Diss}^{-\mathrm{O}}$ & 5.7 & $7-9$ & $3.5-7$ \\
$\mathrm{pH}_{25^{\circ} \mathrm{C}}$ & 6.9 & $6.21-6.81$ & $7.71-9.31$ \\
\hline
\end{tabular}

aNot added.

bNot analyzed.

$\mathrm{CO}_{2}$ to the atmosphere during the tests. Nickel in the effluent is present primarily in the form of corrosion products from the nickel test vessel.

The specimens and the platinum electrode were electrically insulated from the test vessel and load train. The corrosion potential of the specimens and a platinum reference electrode with respect to an external $2 \times 10^{-4} \mathrm{M} \mathrm{KCl} / \mathrm{AgCl} / \mathrm{Ag}$ reference electrode were measured continually during the crack growth tests. The potential of the reference electrode at $93^{\circ} \mathrm{C}$ was expertmentally determined to be $+378 \mathrm{mV} \mathrm{SHE}$, as discussed in section 3.5 and shown in Fig. 55. The corrosion potentlal varted from 376-431, 345-433, 337-403, and 399-497 $\mathrm{mV}$ SHE for the Type 304L SS. Type 316L SS, and Incoloy 825 specimens and the platinum electrode, respectively.

Tenginn-to-tension lnads were applied to specimens with either MTS servohydraulic equipment under load-control or deadload testing machires. A sawtooth cyclic load waveform with varlable rise and unloading time was used at a fixed $R$. Both high-load-ratio $(R \geq 0.9)$ and low-load-ratio $(R=0.5$ or 0.7$)$ tests were conducted; the test conditions are 


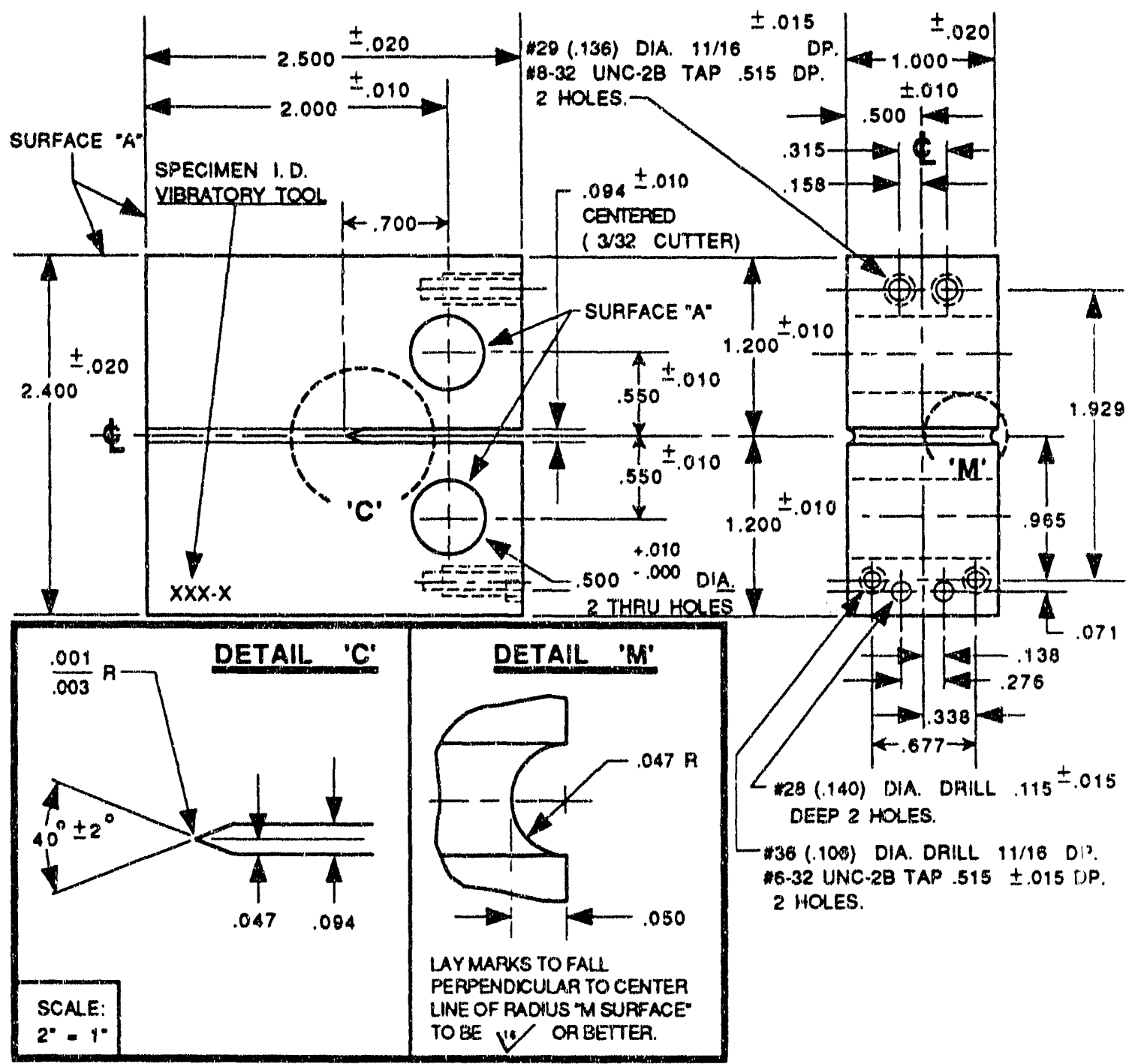

1. "A" GURFACES SHALL QE PERPENUICULAR WITHIN .DOA TIR.

2. THE INTERSECTION OF THE NOTCH TIPS WTTH THE TWO SPECIMEN FACES SHALL BE EOUALIYY DISTANT FROM THE TOP ANO BOTTOM EDGES OF THE SPECIMEN WITHIN .010.

3. "M" SURFACES (SIDE GRCOVES) ANO NOTCH SHALL. BE POSITIONED AS PER DHAWING * NW-DO26A-W2-FO. THIS ORIENTATION MUST EIE IDENTIFIEO AT ALL TIMES DUAING FABRICATION STEPS.

4. UNLESS OTHERWISE NOTED: FRACTIONAL TOLERANCES \pm 1/B4: DECIMA TOLERANCES \pm .005 :

ANGULAAR TOLERANCES $\pm 1 / 4^{\circ}$ : FINISH TOLERANCES $W$. ALL SURFACES TO BE FREE OF BURAS

Fig. 57. Design of Compact Tenston Crack-Growth-Rate Test Spectmen. All dimensions are in inches. 
summarized in Table 24. Three fatigue-precracked specimens were loaded simultaneously in a daisy-chain serial loading arrangement. The crack length in each specimen was continually monitored by means of a electric potential drop method. 15 Potentlal drop across the specimens was about $40-50 \mu \mathrm{V}$ at a measuring current of $2 \mathrm{~A}$, and thermal electromotive force was on the order of $0.7-14 \mu \mathrm{V}$. The resolution of the crack-length measurement was $50 \mu \mathrm{m}$. A schematic representation of the experimental setup is shown in Fig. 58.

\subsection{Results and Discussion}

\subsubsection{High-Load-Ratio Tests}

Specimens of all three alloys were initlally loaded under a constant $(R=1)$ stress intensity of $25 \mathrm{MPa} \cdot \mathrm{m}^{1 / 2}$ in the simulated $\mathrm{J}-13$ well water environment, but no crack growth was observed after $315 \mathrm{~h}$. The load ratio was than decreased to $R=0.95$, thus Imposing a slight "wiggle" on the loading waveform, but no crack growth was observed after an additional $334 \mathrm{~h}$ under these conditions. Following this, $\mathrm{R}$ was further decreased to 0.9 and the tests were continued for an additional 18,300 $\mathrm{h}$ (more than two yr), and again no crack growth was observed. Figures 59-61 show crack length as a function of time for the test times from 9300 to $19,000 \mathrm{~h}$ for the three alloys under $\mathrm{R}=0.9$ loading.

Table 24. Loading Conditions for CGR Tests on Candidate Waste Container Materials

\begin{tabular}{|c|c|c|c|c|}
\hline Alloy & $\underset{(\mathrm{MPa} \cdot \mathrm{m} 1 / 2)}{\mathrm{K}_{\max }}$ & $\begin{array}{l}\text { Load } \\
\text { Ratio }\end{array}$ & $\begin{array}{l}\text { Rise } \\
\text { Time } \\
\text { (s) }\end{array}$ & $\begin{array}{c}\text { Unload } \\
\text { Time } \\
\text { (s) }\end{array}$ \\
\hline \multicolumn{5}{|c|}{ High-Load-Ratio Tests } \\
\hline All & 25 & 1 & - & - \\
\hline All & 25 & 0.95 & 12 & 2 \\
\hline All & 25 & 0.9 & 12 & 2 \\
\hline \multicolumn{5}{|c|}{ Low-Load-Ratio Tests } \\
\hline 304 SS & $\begin{array}{l}35.7-36.2 \\
27.4-28.5\end{array}$ & $\begin{array}{l}0.7 \\
0.5\end{array}$ & $\begin{array}{l}1-500 \\
1-1000\end{array}$ & $\begin{array}{l}1 \\
1\end{array}$ \\
\hline 316 SS & $\begin{array}{l}39.2-39.8 \\
26.8-31.2\end{array}$ & $\begin{array}{l}0.7 \\
0.5\end{array}$ & $\begin{array}{l}1-500 \\
1-1000\end{array}$ & $\begin{array}{l}1 \\
1\end{array}$ \\
\hline Incoloy & $36.4-36.9$ & 0.7 & $1-500$ & 1 \\
\hline 825 & $27.4-28.3$ & 0.5 & $1-500$ & 1 \\
\hline
\end{tabular}




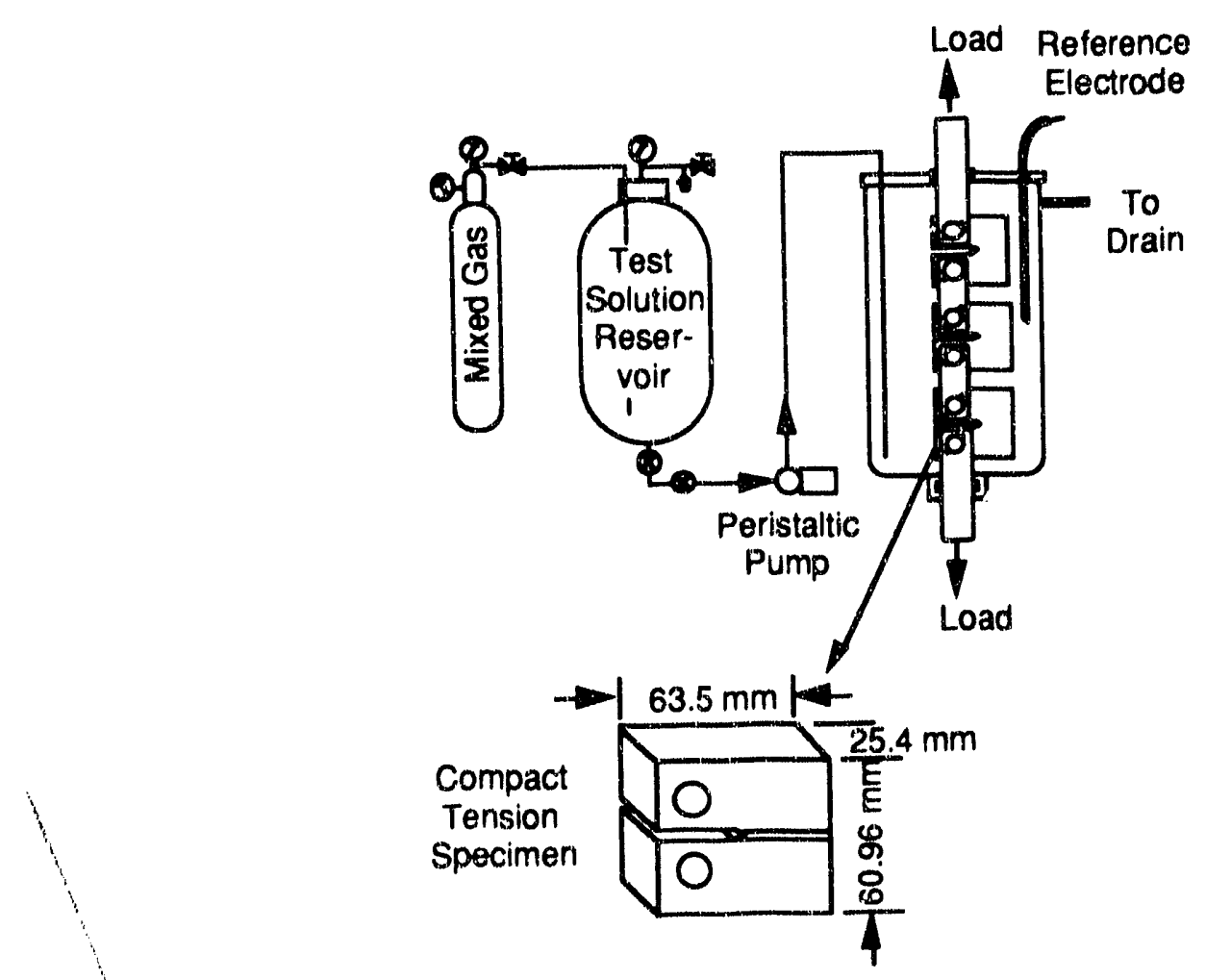

Fig. 58. Schematic Representation of Experimental Setup and Test Spectmen

The inaximum average crack growth rate in these tests can be estimated from the resolution of the crack-growth-measurement technique $(50 \mu \mathrm{m})$ and the time over which no crack extension was detected. Dividing the overall resolution of $50 \mu \mathrm{m}$ by the test duration of $19,000 \mathrm{~h}$ results in an estimated maximum crack growth rate of $\approx 8 \times 10^{-13} \mathrm{~m} / \mathrm{s}$ under the test conditions. This compares with a maximum allowable crack growth rate of $\approx 1 \times 10^{-12} \mathrm{~m} / \mathrm{s}$ for the waste package canister, based upon a wall thickness of $1 \mathrm{~cm}$ and a target life of 300 years.

\subsubsection{Tow-Load-Ratio Tests}

Crack-growth-rate tests in the same environment, conducted under more severe conditions of greater siress intensities and lower $R$ ratios, resulted in observable crack extension. In Fig. 62. Type $304 \mathrm{~L}$ SS under conditions of $\mathrm{R}=0.7, \mathrm{~K}=36 \mathrm{MPa} \cdot \mathrm{m}^{1 / 2}$, and frequency of $0.5 \mathrm{~Hz}$, shows a CGR of $4.0 \times 10^{-9} \mathrm{~m} \cdot \mathrm{s}^{-1}$. The results of cyclic load tests on Types 304L and 316L SS and Incoloy 825 at $R=0.5$ and 0.7 and frequencies of $10^{-3}$ to 1 $\mathrm{Hz}$ are summarized in Table 25. For comparison, fatigue CGRs of austenitic stainless steel in air at $93^{\circ} \mathrm{C}$ computed with the current ASME Section XI correlation, which is based on the work of James and Jones, ${ }^{16}$ are also included.

Figures 63 and 64 show a comparison between the CGRs observed for the test materials in simulated $\mathrm{J}-13$ well water and the predicted growth rates of austenitic stainless steel in atr, based on the ASME Section XI correlation. In the IIgures, growin rates on the solid line (with slope of unity) would be equal to those predicted by the ASME 
correlation. The observed CGRs for Types 304L and 316L SS and Incoloy 825 are generally lower than the predicted rates. Because the code correlation represents a $95 \%$ confidence limit upper bound for the observed data base. It is expected to be conservative for most heats of material in the absence of environmental effects.

Crack growth rate under cyclic loads in a corrosive environment (da/dt) may be expressed as a sum of contributions by (1) stress corrosion cracking. (da/dt)scc: (2) corrosion fatigue, (da/dt) $\mathrm{CF}$, representing the additional crack growth under cyclic loading due to the environment: and (3) mechanical fatigue, (da/dt)air. representing the fatigue growth in air:

$$
(d a / d t)=(d a / d t)_{S C C}+(d a / d t)_{C F}+(d a / d t)_{a i r} .
$$

The first two terms on the right side of the equation are environment-sensitive. They depend on loading history varlables, such as rise-, unload- and hold-time, as well as on frequency. In oxygenated-water environments, the environment-sensitive terms can contribute significantly to crack growth rates of austenitic stainless steels. 17-19 Under low-R and high-frequency loading, mechanical fatigue dominates. Environmental contributions would be expected to become more significant as the frequency decreases. Crack-growth rates as a function of cyclic frequency and CGRs per cycle versus rise time for the current tests are shown in Figs. 65-68. Figures 65 and 66 show that the timebased growth rates are proportional to frequency over the entire range of the frequencies used in the tests. This indicates that no environmental acceleration of crack growth is present for the test conditions considered. Figures 67 and 68 show that the growth rate per cycle is independent of rise time. This too indicates that no environmentally assisted crack growth occurred, and that the crack-growth mechanism is pure mechanical fatigue. For comparison, the environmentally accelerated behavior observed in high-temperature oxygenated environments ${ }^{18,19}$ is shown schematically by the curved lines in Figs. 65 and 66.

\section{Summary and Conclusions}

A series of slow-strain-rate tensile tests on six candidate nuclear waste container materials was conducted under both crevice and noncrevice conditions in simulated well $\mathrm{J}-13$ water at $93^{\circ} \mathrm{C}$ at strain rates of $10^{-7}$ and $10^{-8} \mathrm{~s}^{-1}$. The tests were performed under well-charactertzed environmental conditions. Similar tests were also performed on weldment specimens of Types $304 \mathrm{~L}$ and $316 \mathrm{~L}$ SS, Incoloy $825, \mathrm{Cu}, \mathrm{Cu}-7 \% \mathrm{Al}$, and $\mathrm{Cu}-$ $30 \% \mathrm{Ni}$ at a strain rate of $10^{-7} \mathrm{~s}^{-1}$. The specimens contained small-diameter through-holes (with or without pins of a matching material) to facilitate observation of cracks by scanning electron microscopy (SEM). The SEM observations showed cracking in virtually all of the materials under the severe testing conditions employed. A stress ratio was formulated on the basis of the ratio of the increase in stress following the initiation of local yielding for the materlal in water and the corresponding stress difference for an identicai test in air at the same elongation. A ratio of plastic strain in air to the plastic. strain in the environment (strain ratio), both evaluated at the same stress, was also formulated to describe the cracking susceptibility. Higher values of stress or strain ratio imply greater cracking or SCC susceptibility. The stress or strain ratio appears to be usetul in screening the materlals for SCC, even though the crack depths are small $(<100 \mu \mathrm{m})$. On 
Table 25. Cyclic CGRs, Obseried and Calculated with ASME Section XI Correlation

\begin{tabular}{|c|c|c|c|c|c|}
\hline $\begin{array}{l}\text { Load } \\
\text { Ratio }\end{array}$ & $\begin{array}{l}\text { Freq. } \\
(\mathrm{Hz})\end{array}$ & $\begin{array}{l}\text { Rise } \\
\text { Time } \\
\text { (s) }\end{array}$ & $\begin{array}{l}\mathrm{K}_{\max } \\
(\mathrm{MPa} \\
\left.\mathrm{m}^{1 / 2}\right)\end{array}$ & $\begin{array}{l}\text { Observed } \\
\text { Growth Rate } \\
\left(\mathrm{m} \cdot \mathrm{s}^{-1}\right)\end{array}$ & $\begin{array}{l}\text { ASME XI } \\
\text { Growth Rate } \\
\left(m \cdot s^{-1}\right)\end{array}$ \\
\hline
\end{tabular}

Type $304 \mathrm{~L}$ SS

$\begin{array}{llrl}0.7 & 0.500 & 1 & 35.7 \\ 0.7 & 0.167 & 5 & 35.9 \\ 0.7 & 0.091 & 10 & 36.0 \\ 0.7 & 0.048 & 20 & 36.0 \\ 0.7 & 0.020 & 50 & 36.1 \\ 0.7 & 0.010 & 100 & 36.1 \\ 0.7 & 0.005 & 200 & 36.1 \\ 0.7 & 0.002 & 500 & 36.2 \\ 0.5 & 0.500 & 1 & 27.4 \\ 0.5 & 0.091 & 10 & 27.8 \\ 0.5 & 0.048 & 20 & 28.0 \\ 0.5 & 0.020 & 50 & 28.1 \\ 0.5 & 0.010 & 100 & 28.2 \\ 0.5 & 0.005 & 200 & 28.3 \\ 0.5 & 0.002 & 500 & 28.4 \\ 0.5 & 0.001 & 1000 & 28.5\end{array}$

$\begin{array}{ll}3.96 \times 10^{-9} & 8.37 \times 10^{-9} \\ 1.62 \times 10^{-9} & 2.83 \times 10^{-9} \\ 7.64 \times 10^{-10} & 1.56 \times 10^{-9} \\ 4.41 \times 10^{-10} & 8.19 \times 10^{-10} \\ 2.31 \times 10^{-10} & 3.39 \times 10^{-10} \\ 9.73 \times 10^{-11} & 1.72 \times 10^{-10} \\ 4.91 \times 10^{-11} & 8.64 \times 10^{-11} \\ 2.29 \times 10^{-11} & 3.48 \times 10^{-11} \\ 1.55 \times 10^{-8} & 1.59 \times 10^{-8} \\ 2.15 \times 10^{-9} & 3.01 \times 10^{-9} \\ 7.89 \times 10^{-10} & 1.61 \times 10^{-9} \\ 3.96 \times 10^{-10} & 6.76 \times 10^{-10} \\ 1.78 \times 10^{-10} & 3.46 \times 10^{-10} \\ 9.40 \times 10^{-11} & 1.76 \times 10^{-10} \\ 3.94 \times 10^{-11} & 7.14 \times 10^{-11} \\ 1.95 \times 10^{-11} & 3.59 \times 10^{-11}\end{array}$

Type 316L SS

$\begin{array}{rrrr}0.7 & 0.500 & 1 & 39.2 \\ 0.7 & 0.167 & 5 & 39.4 \\ 0.7 & 0.091 & 10 & 39.6 \\ 0.7 & 0.048 & 20 & 39.6 \\ 0.7 & 0.020 & 50 & 39.7 \\ 0.7 & 0.010 & 100 & 39.7 \\ 0.7 & 0.005 & 200 & 39.7 \\ 0.7 & 0.002 & 500 & 39.8 \\ 0.5 & 0.500 & 1 & 26.8 \\ 0.5 & 0.091 & 10 & 30.0 \\ 0.5 & 0.048 & 20 & 30.3 \\ 0.5 & 0.020 & 50 & 30.6 \\ 0.5 & 0.010 & 100 & 30.8 \\ 0.5 & 0.005 & 200 & 31.0 \\ 0.5 & 0.002 & 500 & 31.1 \\ 0.5 & 0.001 & 1000 & 31.2\end{array}$

$\begin{array}{ll}4.09 \times 10^{-9} & 1.14 \times 10^{-8} \\ 1.93 \times 10^{-9} & 3.87 \times 10^{-9} \\ 9.66 \times 10^{-10} & 2.13 \times 10^{-9} \\ 5.25 \times 10^{-10} & 1.12 \times 10^{-9} \\ 2.06 \times 10^{-10} & 4.64 \times 10^{-10} \\ 6.81 \times 10^{-11} & 2.35 \times 10^{-10} \\ 3.10 \times 10^{-11} & 1.18 \times 10^{-10} \\ 1.82 \times 10^{-11} & 4.76 \times 10^{-11} \\ 2.33 \times 10^{-8} & 2.02 \times 10^{-8} \\ 3.97 \times 10^{-9} & 3.88 \times 10^{-9} \\ 1.12 \times 10^{-9} & 2.10 \times 10^{-9} \\ 5.65 \times 10^{-10} & 8.91 \times 10^{-10} \\ 2.69 \times 10^{-10} & 4.60 \times 10^{-10} \\ 1.34 \times 10^{-10} & 2.36 \times 10^{-1} 10 \\ 5.36 \times 10^{-11} & 9.58 \times 10^{-11} \\ 2.64 \times 10^{-11} & 4.84 \times 10^{-11}\end{array}$

Incoloy $\mathbf{8 2 5}$

$\begin{array}{llrlll}0.7 & 0.500 & 1 & 36.4 & 4.89 \times 10^{-9} & 8.86 \times 10^{-9} \\ 0.7 & 0.167 & 5 & 36.6 & 1.56 \times 10^{-9} & 3.01 \times 10^{-9} \\ 0.7 & 0.091 & 10 & 36.7 & 9.55 \times 10^{-10} & 1.66 \times 10^{-9} \\ 0.7 & 0.048 & 20 & 36.7 & 5.28 \times 10^{-10} & 8.74 \times 10^{-10} \\ 0.7 & 0.020 & 50 & 36.8 & 1.60 \times 10^{-10} & 3.61 \times 10^{-10} \\ 0.7 & 0.010 & 100 & 36.8 & 9.73 \times 10^{-11} & 1.83 \times 10^{-10} \\ 0.7 & 0.005 & 200 & 36.9 & 5.84 \times 10^{-11} & 9.23 \times 10^{-11} \\ 0.7 & 0.002 & 500 & 36.9 & 2.62 \times 10^{-11} & 3.72 \times 10^{-11} \\ 0.5 & 0.500 & 1 & 27.4 & 9.05 \times 10^{-9} & 1.58 \times 10^{-8} \\ 0.5 & 0.091 & 10 & 27.6 & 1.70 \times 10^{-9} & 2.96 \times 10^{-9} \\ 0.5 & 0.048 & 20 & 27.8 & 7.04 \times 10^{-10} & 1.58 \times 10^{-9} \\ 0.5 & 0.020 & 50 & 27.9 & 3.54 \times 10^{-10} & 6.61 \times 10^{-10} \\ 0.5 & 0.010 & 100 & 28.1 & 1.67 \times 10^{-10} & 3.39 \times 10^{-10} \\ 0.5 & 0.005 & 200 & 28.2 & 1.22 \times 10^{-10} & 1.72 \times 10^{-10} \\ 0.5 & 0.002 & 500 & 28.3 & 3.88 \times 10^{-11} & 6.99 \times 10^{-11}\end{array}$




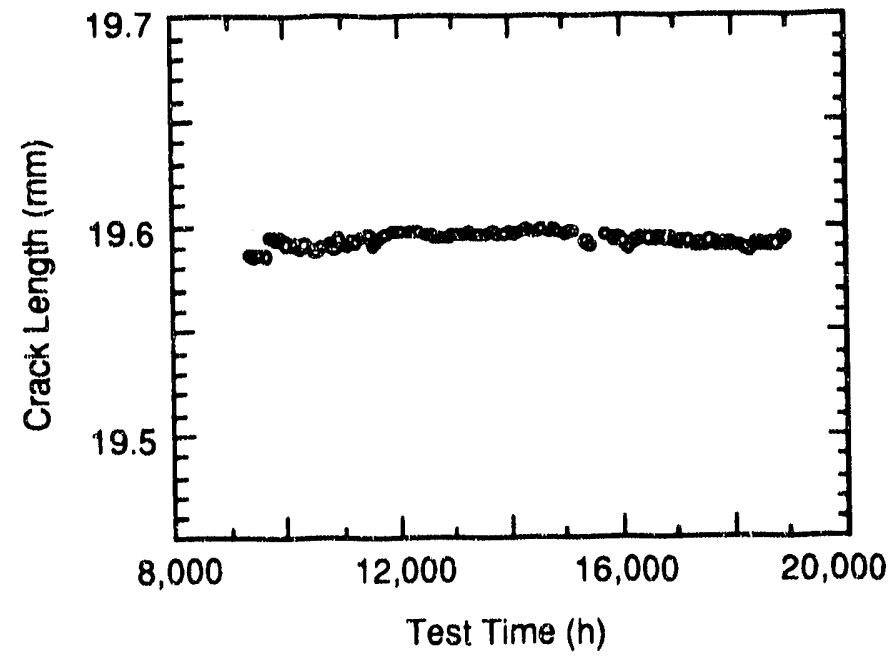

Fig. 59. Crack Length vs. Test Time for Type 304L $\mathrm{SS}$ at $K_{\max }=25 \mathrm{MPa} \cdot \mathrm{m}^{1 / 2}$ and $R=0.9$

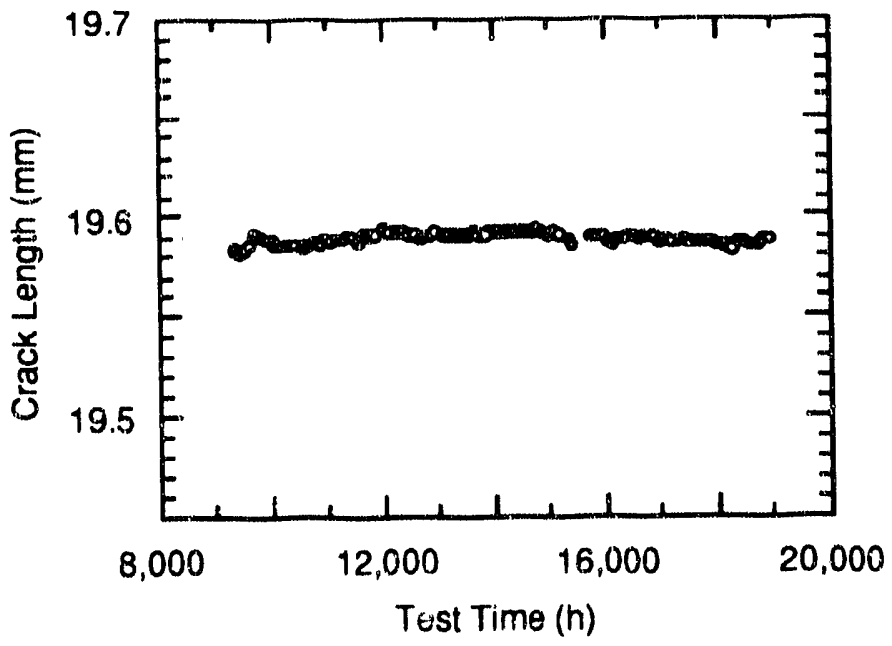

Fig. 60. Crack Length vs. Test Tyme for Type 316L $S S$ at $K_{\max }=25 \mathrm{MPa} \cdot \mathrm{m}^{1 / 2}$ and $R=0.9$ 


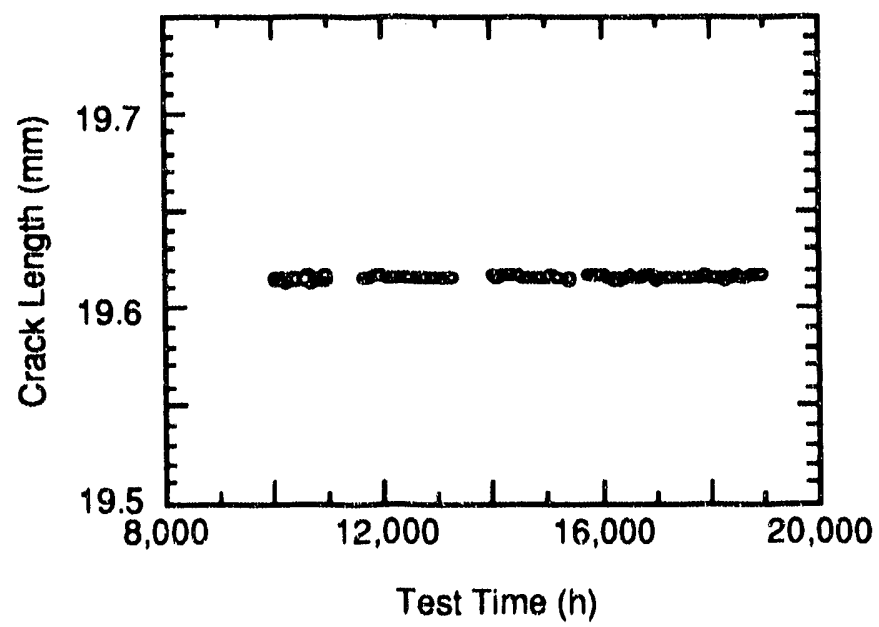

Fig. 61. Crack Length us. Test Time for Incoloy 825 at $K_{\max }=25 \mathrm{MPa} \cdot \mathrm{m}^{1 / 2}$ and $R=0.9$

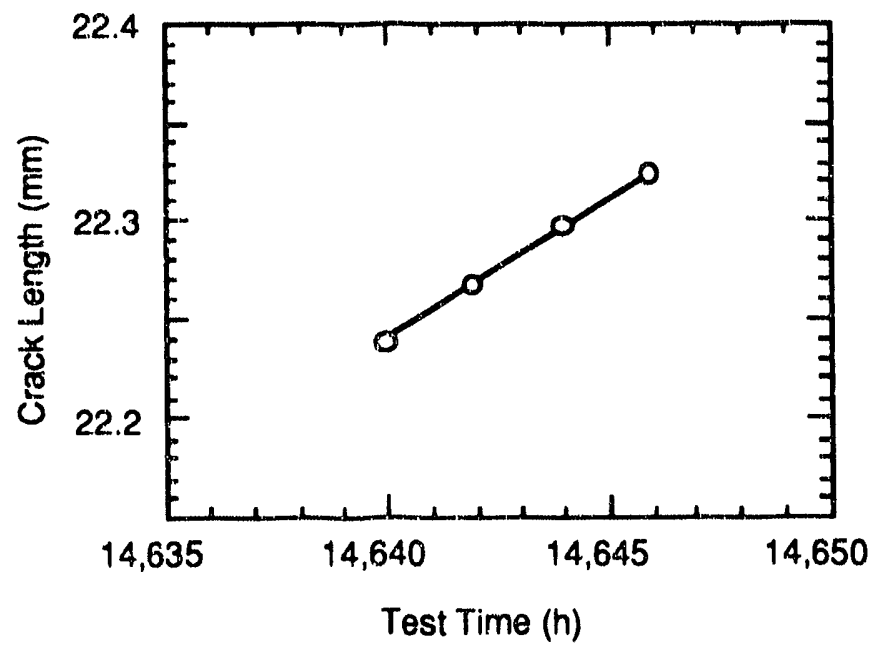

FYg. 62. Crack Length vs. Test Time for 304L SS at $K_{\max }=36 \mathrm{MPa} \cdot \mathrm{rn}^{1 / 2}, R=0.7$ and $0.5 \mathrm{~Hz}$ 


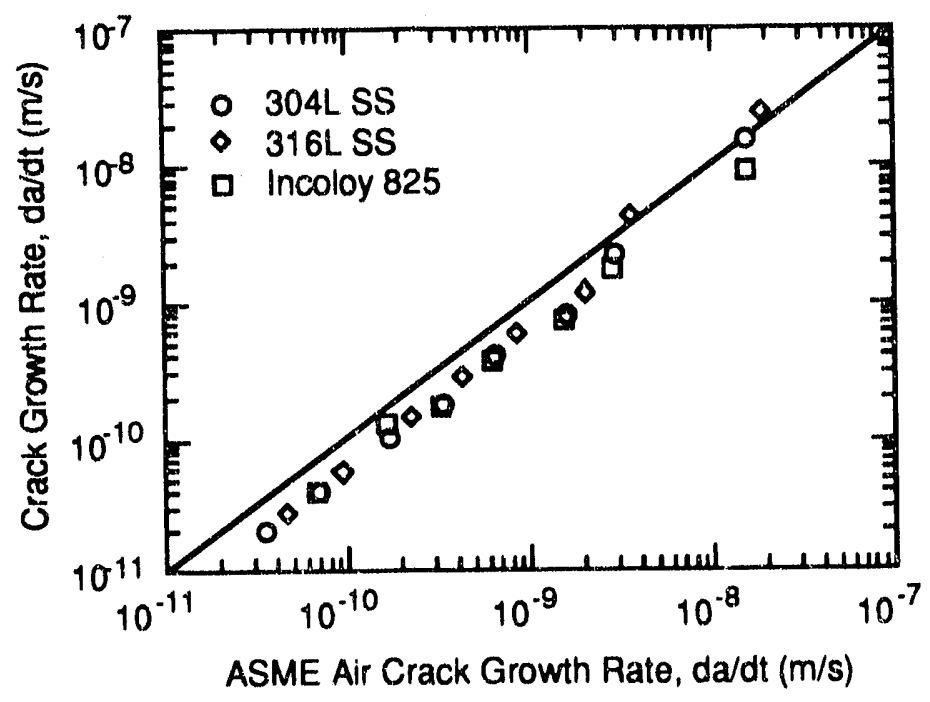

Fig. 63. Time-Based CGR us. Rate for Austenitic Stainless Steels in Air from ASME Section $X I$ Correlation for $R=0.5$

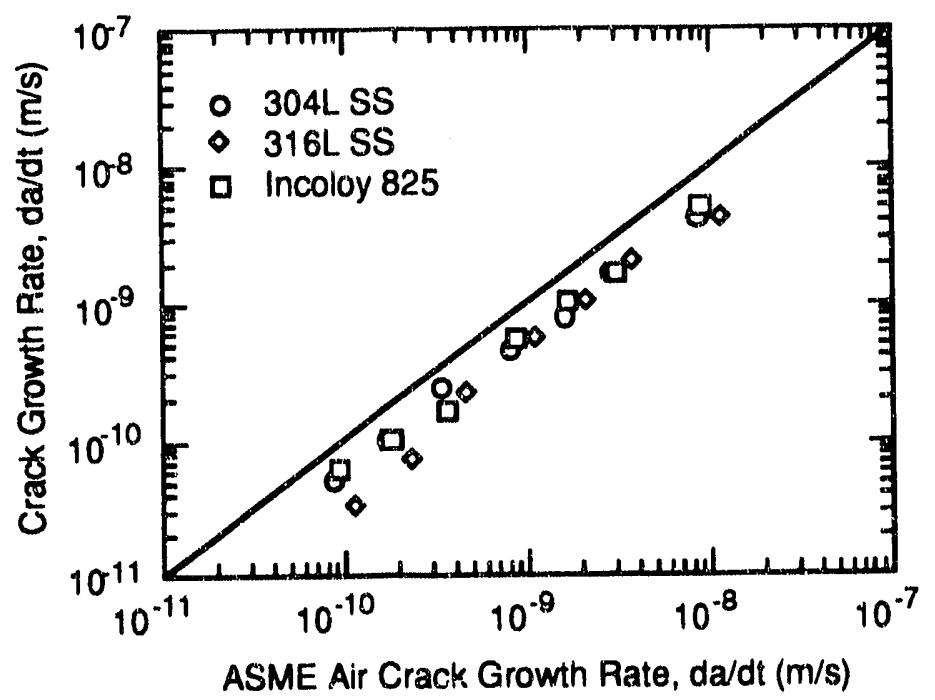

Fig. 64. Time-Based CGR vs. Rate for Austenitic Stainless Steels in Air from ASME Section $X I$ Correlation for $R=0.7$ 


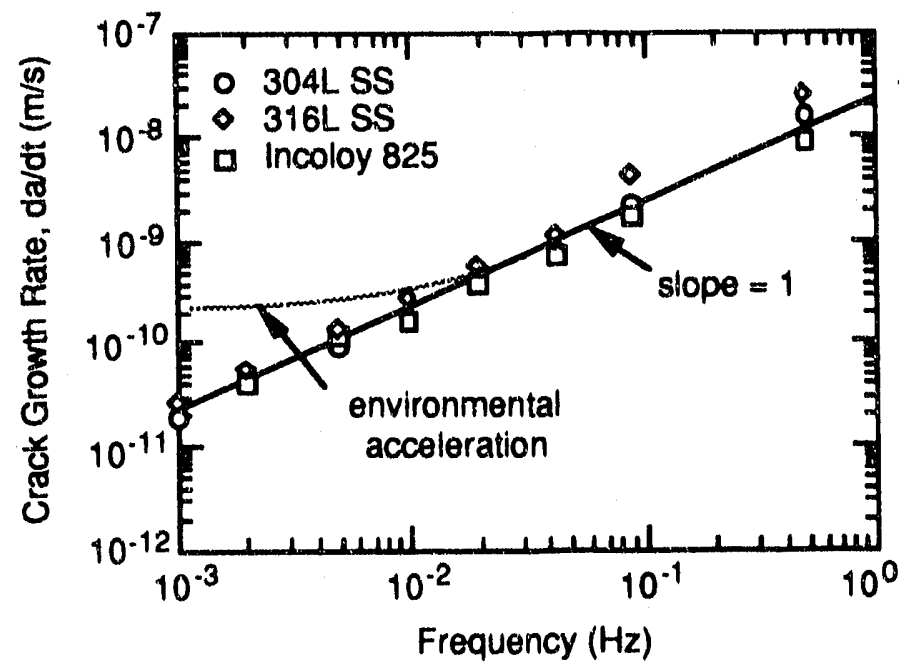

Fig. 65. Tume-Based CGR us. Frequency at $R=0.5$

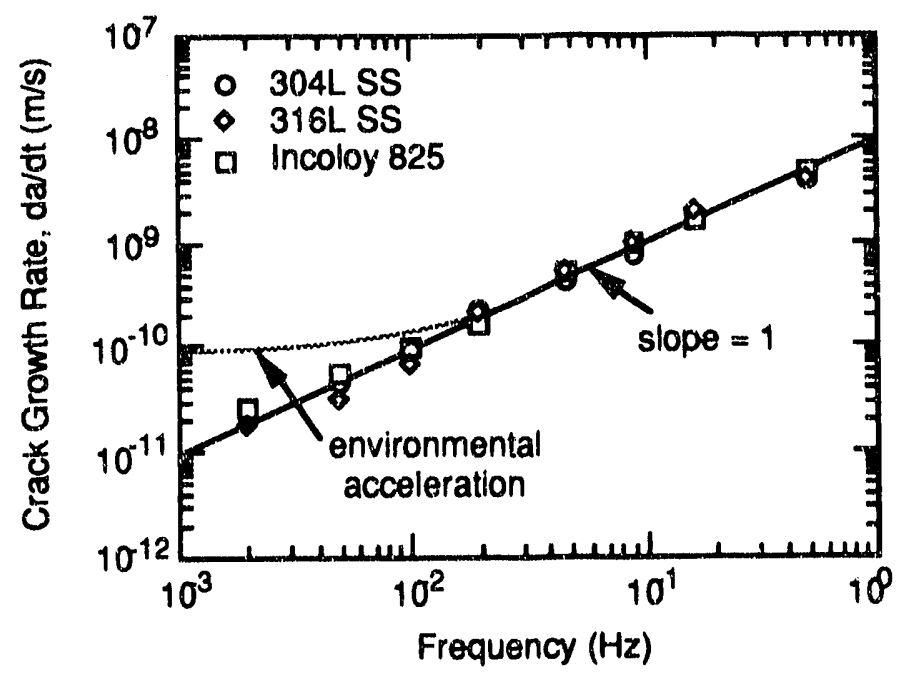

Fig. 66. Tune-Based CGR vs. Frequency at $R=0.7$ 


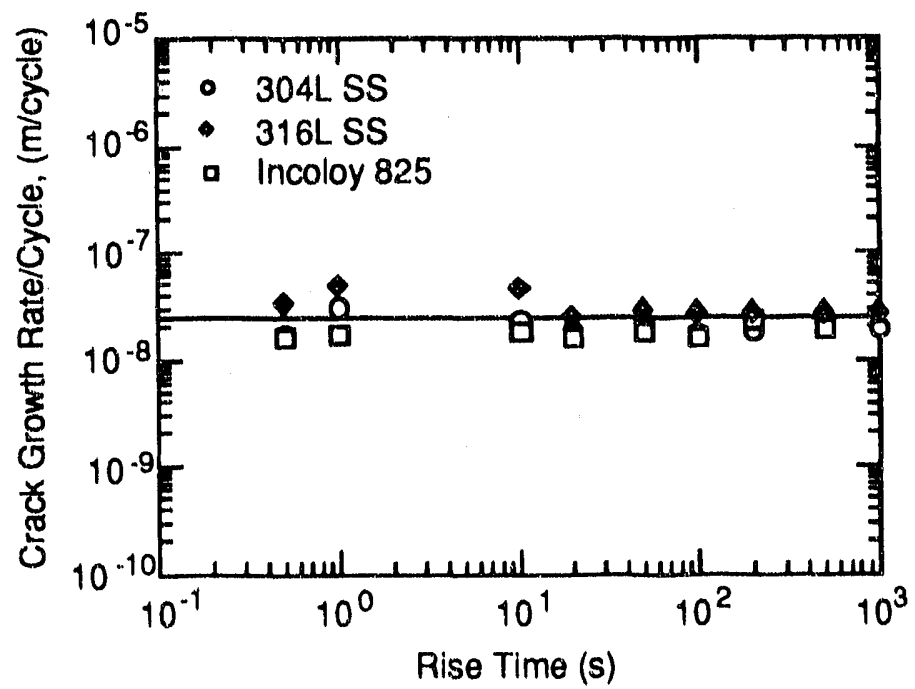

Fig. 67. CGR per Cycle as a Function of Rise Time for $R=0.5$

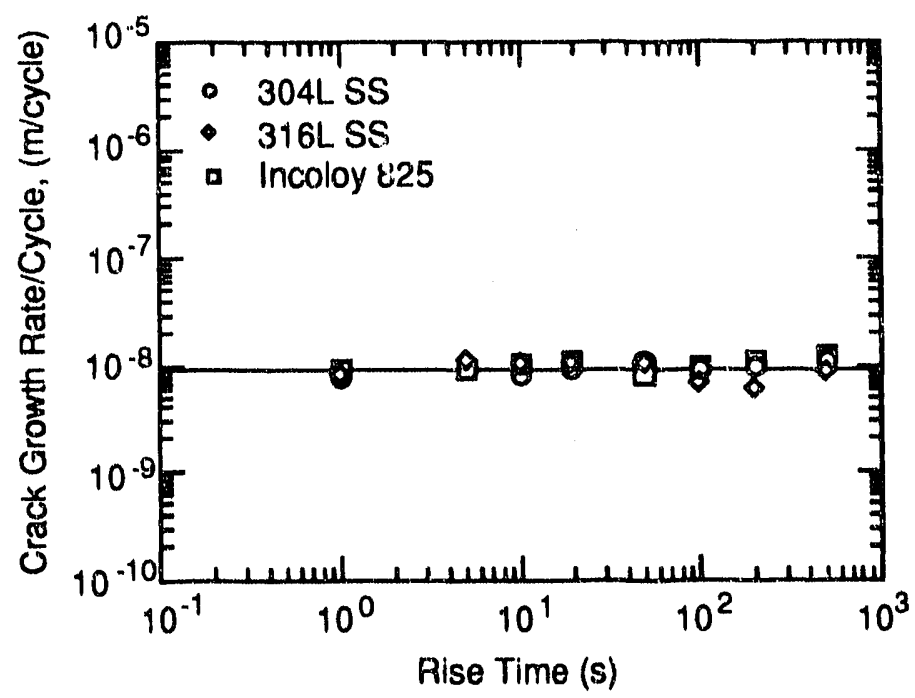

Fig. 68. CGR per Cycle as a Function of Rise Time for $R=0.7$ 
the basis of this stress ratio or strain ratio, the ranking of the materials in order of increasing resistance to cracking is Type 304L SS < Type 316L SS < Incoloy $825<\mathrm{Cu}$ $30 \% \mathrm{Ni}<\mathrm{Cu}$ and $\mathrm{Cu}-7 \% \mathrm{Al}$. Weldment specimens of $\mathrm{Cu}-30 \% \mathrm{Ni}$ and $\mathrm{Cu}$ exhlbited a somewhat higher susceptlbllity to cracking in terms of the index compared to the base metal specimens. The cracking index also suggests that a lower strain rate has a deleterious effect on cracking of 1ypes 304L and 316L SS, Incoloy 825, and Cu, but has virtually no effect on $\mathrm{Cu}-30 \% \mathrm{NI}$ and $\mathrm{Cu}-7 \% \mathrm{Al}$. The relative SCC susceptibility of these materlals from the preliminary SSRT tests is being confirmed by tests on fracturemechanics-type specimens.

Fracture-mechanics crack-growth tests were conducted on 25.4-mm-thick compact tension specimens of Types $304 \mathrm{~L}$ and $316 \mathrm{~L}$ SS and Incoloy 825 at $93^{\circ} \mathrm{C}$ and $1 \mathrm{~atm}$ of pressure in simulated J-13 well water in both high-and low-load-ratio tests. In the high-load-ratio tests, $K_{\max }$ was $25 \mathrm{MPa} \cdot \mathrm{m}^{1 / 2}$ and $\mathrm{R}$ ranged from 0.9 to 1 . In the lowload-ratio tests, $\mathrm{K}_{\max }$ ranged from 26.8 to $39.8 \mathrm{MPa} \cdot \mathrm{m}^{1 / 2}$ and $\mathrm{R}$ was 0.5 or 0.7 . The results of these experiments lead to the following conclusions: (1) No crack growth was detected in any of the alloys tested at $\mathrm{K}=25 \mathrm{MPa} \cdot \mathrm{m}^{1 / 2}$ and $\mathrm{R}=0.9-1$ for test times of $19.000 \mathrm{~h}$. Based on the resolution of the crack-length-measuring technique, this indicates that the maximum average crack growth rate under these conditions was $\approx 8 \times 10^{-13} \mathrm{~m} / \mathrm{s}$. (2) No cyclic or rise-time-dependent environmental acceleration of crack growth was observable in the simulated $\mathrm{J}-13$ well water at $93^{\circ} \mathrm{C}$ under the test conditions. (3) Growth rates for $R$ $=0.5-0.7$ and maximum stress intensities of 26-40 MPa $\mathrm{m}^{1 / 2}$ agree with the current ASME Section XI correlation for austenitic stainless steel within a factor of 0.9-3.8.

\section{Ackriowledgments}

D. R. Perkins, W. F. Burke, W. E. Ruther, W. K. Soppet, S. L. Phillips, and J. C. Tezak of Argonne National Laboratory contributed to various experimental aspects of the project. E. A. Huff, A. M. Essling, and F. P. Smith analyzed the water from the SSRT tests. The authors thank W. L. Clarke and R. D. McCright of Lawrence Livermore National Laboratory for their support of this work, which was sponsored by the U.S. Department of Energy under subcontract from Lawrence Livermore National Laboratory.

\section{References}

1. R. V. Guzowski, F. B. Nimick, M. D. Siegel, and N. C. Finely, Repository Site Data Report for Tuff: Yucca Mountain, Nevada, NUREG/CR-2937, SAND82-2105, Sandia National Laboratories (Oct. 1983).

2. A. E. Ogard and J. F. Kerrisk, Groundwater Chemistry along Flow Path Between a Proposed Repository Site and the Accessible Environment, LA-1088-MS, Los Alamos National Laboratory (1984).

3. J. C. Farmer and R. D. McCright, A Review of Models Relevant to the Prediction of Performance of High-Level Radioactive Waste Disposal Containers, CORROSION 89, New Orleans, Paper 519, National Association of Corrosion Engineers, Houston (1989). 
4. R. D. McCright, FY 1985 Status Report on Feasiblity Assessment of Copper-Base Waste Package Container Materlals in a Tuff Repository. UCID-20509 DE86003960. Lawrence Livermore National Laboratory (Sept. 30, 1985).

5. P. S. Maiya, Constant Extension Rate Tests, in Environmentally Assisted Cracking, Light Water Reactors: Semiannual Report April-September 1986, NUREG/CR-4667. Vol. III, Argonne National Laboratory Report ANL-87-37 (Sept. 1987).

6. P. S. Malya, Effects of Plastic Strain, Environment, and Crevices on Stress Corrosion Crack Initiation and Propagation in Types 316NG and 304 Stainless Steel. Corrosion. 46. No. 11, pp. 915-914 (1989).

7. W. Ramberg and W. R. Osgood. Description of Stress-Strain Curves by Three Parameters, NACA Technical Note No. 902 (July 1943).

8. H. Neuber, Theory of Stress Concentration for Shear Strained Prismatical Bodies with Arbitrary Non-linear Stress-Strain Law. ASME J. Appl. Mech., 28, pp. 544-550 (1961).

9. P. S. Malya and W. J. Shack, Evaluatton of Nonenutronmental Corrective Actions, in Environmentally Assisted Cracking in Light Water Reactors: Annual Report October 1982--September 1983, NUREG/CR-3806. Argonne National Laboratory Report ANL84-36, p. 58 (June 1984).

10. W. J. Shack, private communication, Argonne National Laboratory (1990).

11. R. K. ller, The Chemistry of Sillica, John Wiley \& Sons, New York, pp. 3-59 (1979).

12. H. H. Uhlig, ed., Corrosion Handbook, John Wiley \& Sons, New York, pp. 500-503 (1948).

13. R. T. Hanlon, A. J. Steffen, G. A. Rohlich, and L. H. Kessler, Scale and Corrosion Control in Potable Water Supplies at Army Posts, Ind. Eng. Chem., 37, 724-735 (1945).

14. Standard E 399-83, Standard Test Method for Plane-Strain Fracture Toughness of Metallic Materials, in Annua' Book of ASTM Standards, Vol. 03.01, American Society for Testing and Materials, Philadelphla, pp. 487-511 (1989).

15. T. A. Prater, W. R. Catlin, and L. F. Coffin, Envtronmental Crack Growth Measurement Techniques, EPRI NP-2641, Electric Power Research Institute, Palo Alto, CA (1982).

16. L. A. James and D. P. Jones, Fatigue Crack Growth Correlation for Austenitic Stainless Steels in Atr. Proc. Conference on Predictive Capabilities in Environmentally-Assisted Cracking, R. Rungta, ed., PVP Vol. 99, American Society of Mechanical Engineers, New York, pp. 363-414 (1985). 
17. T. Kawakubo, M. Hishida, K. Amano, and M. Katsuta, Crack Growth Behavior of Type 304 Stainless Steel in Oxygenated $290^{\circ} \mathrm{C}$ Pure Water under Low Frequency Cyclic Loading, Corroslon, 36. 638-647 (1980).

18. J. D. Gilman, R. Rungta, P. Hinds, and H. Mindlan, Corrosion-Fatigue Crack Grouth Rates in Austenitic Stainless Steels in Light Water Reactor Environments, Int. J. Pres. Ves. \& Piping 31, 55-68 (1988).

19. W. J. Shack, Corrosion Fatigue Curves for Austenttic Stainless Steels in Light Water Reactor Environments, in Environmentally Assisted Cracking in Light Water Reactors, Semlannual Report, October 1990-March 1991," NUREG/CR-4667. Vol.12. Argonne National Laboratory Report ANL-91/24, pp. 30-36 (Aug. 1991). 
Distribution for_ANh-92/28

Internal

J. K. Bates

S. S. Barys

K. Brubaker

J. C. Burton

O. K. Chopra

J. C. Cunnane

D. R. Dlercks

J. D. Ditmans

W. Harrison

A. B. Hull
T. Jennings

T. F. Kassner

P. S. Matya

C. A. Malefyt (2)

V. A. Maroni

Z. Nagy

K. Natesan

L. A. Netmark

J. Y. Park (50)

P. J. Peterson
R. B. Poeppel

D. T. Reed

W. E. Ruther

W. J. Shack

W. K. Soppet

C. E. TU1!

R. W. Weeks

ANL Patent Dept.

ANL Contract Flle

TIS Files (3)

\section{External}

DOE-OSTI for distribution per UC-504 and UC-510 (237)

ANL-MS Libraries

Chicago Operations Office, DOE:

D. T. Goldman

F. Herbaty

A. L. Taboas

Materials and Components Technology Division Review Committee:

H. Berger, Industrial Quality, Inc., Gatthersburg, MD

H. Birnbaum. Untversity of Illinois at Urbana-Chanpaign. Urbana

R. Buchanan. Untversity of Illinols at Urbana-Char pałg, Urbana

M. S. Dresselhaus, Massachusetts Institute of Technology, Cambridge, MA

R. A. Greenkorn。 Purdue University, West Lafayette, IN

B. Jones. University of Illinols at Urbana-Champalgn. Urbana

C.-Y. Ld, Cornell Untversity, Ithaca, NY

R. E. Smith. Electric Power Research Institute, NDE Ctr., Charlotte. NC

W. L. Clarke, Lawrence Ltvermore National Laboralory

J. R. Crum, INCO Alloys International. Huntington, WV

J. H. DeVan, Oak Ridge National Laboratory

J. N. Kass, Lawrence Livermore National Laboratory

W. S. Lyman, Copper Development Association, inc., Greenwich. CT

R. D. McCright, Lawrence Ltvermore National Laboratory

M. A. Molecke. Sandia National Laboratories

E. Smallos, Kernforschurigszentrum Karlsruhe, Karlsruhe, FRG

R. Van Konyenburg. Lawrence Livermore National Laboratory

R. E. Westerman, Battelle Pacific Northwest Laboratorles

B. E. Wulde. Ohio State Untversily, Columbus. 
$=$ 